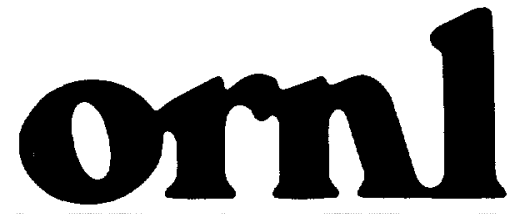

OAK RIDGE NATIONAL LABORATORY
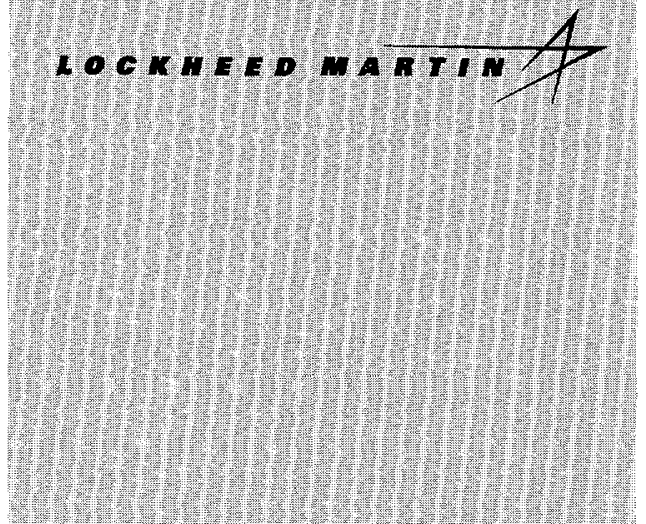

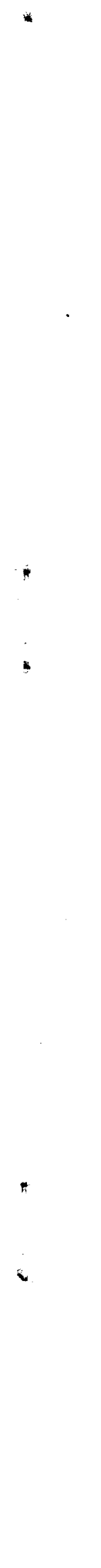

Results of Parametric Design Studies of MOX Lead Test Assembly

Project Manager

A. M. Pavlovitchev

Executed by

S. A. Bychkov

A. A. Lazarenko

V. D. Sidorenko Y. A. Styrin
NANAGED AND OPERATED BY LOCKHEED WARTN ENERGY RESEARCH CORPORATION FOA THE UNTED STATES DEPARTMENT OF ENERGY 
This report has been reproduced from the best available copy.

Reports are available to the public from the following source.

National Technical information Service

5285 Port Royal Road

Springfield, VA 22161

Telephone 703-605-6000 (1-800-553-6847)

TDD 703-487-4639

Fax 703-605-6900

E-mail orders@ntis.fedworld.gov

Web site http://www.ntis.gov/ordering.htm

Reports are available to U.S. Department of Energy (DOE) employees, DOE contractors, Energy Technology Data Exchange (ETDE) representatives, and International Nuclear Information System (INIS) representatives from the following source.

Office of Scientific and Technical Information.

P.O. Box 62

Oak Ridge, TN 37831

Telephone 423-576-8401

Fax 423-576-5728

E-mail reports@adonis.osti.gov

Web site http:/www.osti.gov/products/sources.html

Reports produced after January 1, 1996, are generally available via the DOE Information Bridge.

Web site http://www.doe.gov/bridge

This report was prepared as an account of work sponsored by an agency of the United States Government. Neither the United States Government nor any agency thereof, nor any of their employees, makes any warranty, express or implied, or assumes any legal liability or responsibility for the accuracy, completeness, or usefulness of any information, apparatus, product, or process disclosed, or represents that its use would not infringe privately owned rights. Reference herein to any specific commercial product, process, or service by trade name, trademark, manufacturer, or otherwise, does not necessarily constitute or imply its endorsement, recommendation, or favoring by the United States Government or any agency thereof. The views and opinions of authors expressed herein do not necessarily state or reflect those of the United States Government or any agency thereot. 


\section{DISCLAIMER}

Portions of this document may be illegible in electronic image products. Images are produced from the best available original document. 


\title{
RESULTS OF PARAMETRIC DESIGN STUDIES OF MOX LEAD TEST ASSEMBLY
}

\author{
Project Manager \\ A. M. Pavlovitchev \\ Executed by \\ S. A. Bychkov \\ A. A. Lazarenko \\ V. D. Sidorenko \\ Y. A. Styrin
}

Date Published: December 1998

\author{
Report Prepared by \\ LOCKHEED MARTIN ENERGY RESEARCH CORP. \\ P.O. Box 2008 \\ Oak Ridge, Tennessee 37831-6363 \\ under \\ Subcontract Number 85B99398V \\ Funded by \\ Office of Fissile Materials Disposition \\ United States Department of Energy \\ Prepared for \\ Computational Physics and Engineering Division \\ Oak Ridge National Laboratory \\ Oak Ridge, Tennessee 37831 \\ managed by \\ LOCKHEED MARTIN ENERGY RESEARCH CORP. \\ for the \\ U.S. DEPARTMENT OF ENERGY \\ under contract DE-96OR22464
}




\title{
Russian Research Center "Kurchatov Institute" \\ Institute of Nuclear Reactors VVER Division
}

\begin{abstract}
Joint U.S. / Russian Project to Update, Verify and Validate Reactor Design/Safety Computer Codes Associated with Weapons-Grade Plutonium Disposition in WER Reactors
\end{abstract}

\section{Results of Parametric Design Studies of MOX Lead Test Assembly}

(Final Report for FY98)

Project Manager

A.M.Pavlovitchev

Executed by

S.A.Bychkov

A.A. Lazarenko

V.D. Sidorenko

Y.A.Styrin 


\section{ACRONYMS}

\begin{tabular}{|c|c|}
\hline BOC & beginning of cycle \\
\hline BPR & boron poison rod \\
\hline CR & control rod \\
\hline EOC & end of cycle \\
\hline FP & fission products \\
\hline LTA & lead test assembly \\
\hline MOX & mixed oxide \\
\hline SOR & system of regulation \\
\hline UOX & uranium oxide \\
\hline VVER & Russian water-water reactor \\
\hline
\end{tabular}


RUSSIAN RESEARCH CENTER KURCHATOV INSTITUTE

Results of Parametric Design Studies of MOX Lead Test Assembly (Final Report for FY98)

\section{EXECUTIVE SUMMARY}

In this document the results of parametric neutronics studies of MOX LTA design are presented. Two options of MOX LTA design are considered: 100\% plutonium and of "island" type. The main part of studies is executed by the Russian code TVS-M. 
RUSSIAN RESEARCH CENTER KURCHATOV INSTITUTE

Results of Parametric Design Studies of MOX Lead Test Assembly (Final Report for FY98)

\section{CONTENTS}

INTRODUCTION

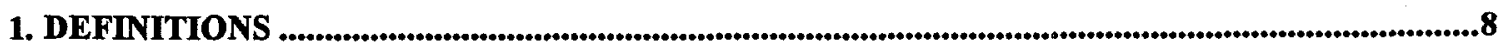

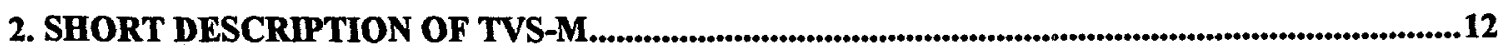

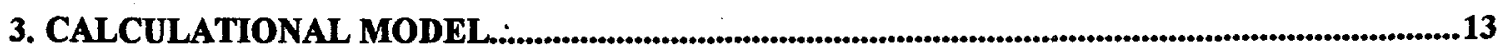

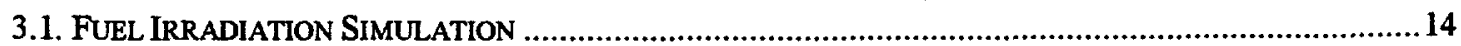

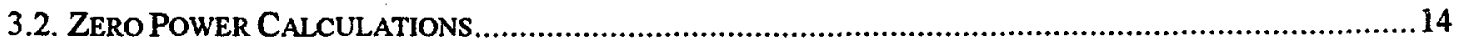

4. CALCULATIONS OF $100 \%$ PLUTONIUM MOX LTA ...............................................................

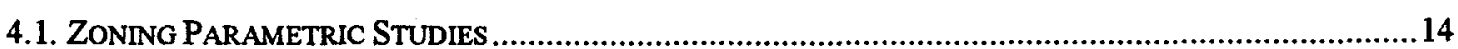

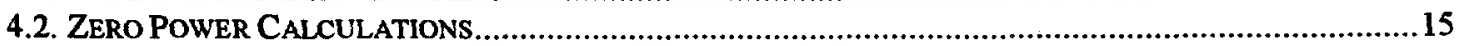

5. CALCULATIONS OF “ISLAND" TYPE MOX LTA.........................................................................16

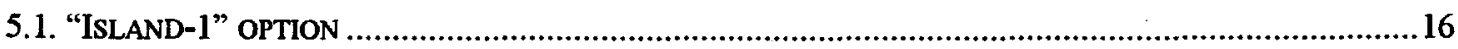

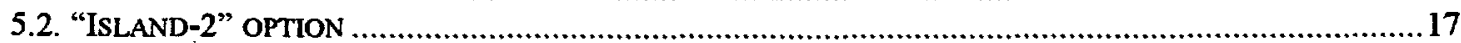

5.3 "PLUTONIUM ISLAND" SIZE VARIATION

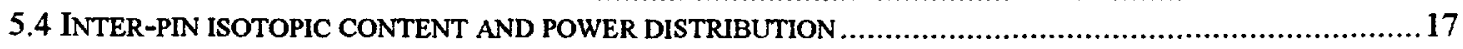

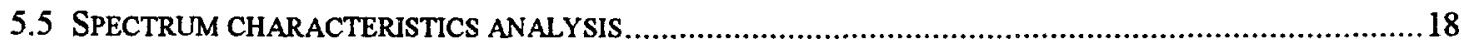

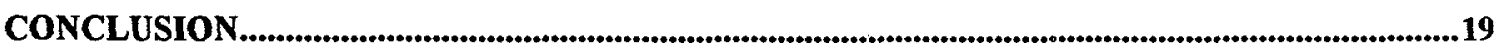

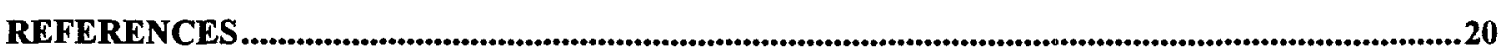

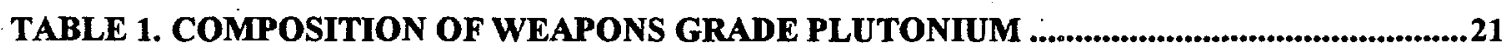

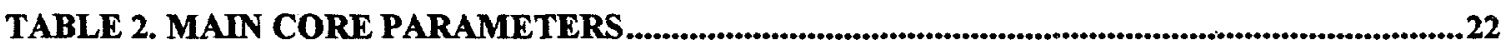

TABLE 3. FUEL ASSEMBLY DESIGN PARAMETERS...............................................................23

TABLE 4. URANIUM FUEL PIN DESIGN PARAMETERS.....................................................................24

TABLE 5. MOX FUEL PIN DESIGN PARAMETERS .......................................................................25

TABLE 6. DISCRETE BURNABLE POISON PIN DESIGN PARAMETERS...................................26

TABLE 7. KEFF IN ZERO POWER STATES

TABLE 8. PARAMETERS EVOLUTION IN THE PROCESS OF FUEL IRRADIATION. REFERENCE URANIUM ASSEMBLAGE. NO BPR.........................................................................28

TABLE 9. PARAMETERS EVOLUTION IN THE PROCESS OF FUEL IRRADIATION.

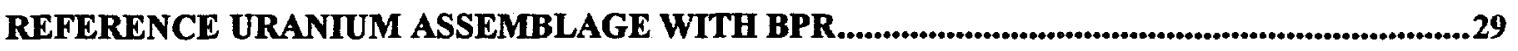

TABLE 10. PARAMETERS EVOLUTION IN THE PROCESS OF FUEL IRRADIATION. MOX

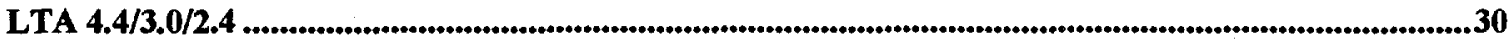


TABLE 11. PARAMETERS EVOLUTION IN THE PROCESS OF FUEL IRRADIATION. MOX LTA 4.4/3.0/2.0

TABLE 12. PARAMETERS EVOLUTION IN THE PROCESS OF FUEL IRRADIATION. MOX LTA 4.4/3.2/2.0

TABLE 13. PARAMETERS EVOLUTION IN THE PROCESS OF FUEL IRRADIATION. MOX LTA 4.2/3.0/2.0

TABLE 14. PARAMETERS EVOLUTION IN THE PROCESS OF FUEL IRRADIATION. MOX LTA 3.8/2.8/U-3.7

FIGURE 2. CALCULATIONAL MODEL FOR REFERENCE URANIUM ASSEMBLY SURROUNDED BY URANIUM ASSEMBLIES. $60^{\circ}$ SECTOR. .36

FIGURE 3. SIMPLIFIED DESIGN FOR 3-ZONES (100\% PLUTONIUM) MOX LTA. .37

FIGURE 4. CALCULATIONAL MODEL FOR 3-ZONES (100\% PLUTONIUM) MOX LTA SURROUNDED BY URANIUM ASSEMBLIES. $60^{\circ}$ SECTOR. .38

FIGURE 5. SIMPLIFIED DESIGN FOR "ISLAND-1" TYPE MOX LTA. 39

FIGURE 6. CALCULATIONAL MODEL FOR "ISLAND-1" MOX LTA SURROUNDED BY URANIUM ASSEMBLIES. $60^{\circ}$ SECTOR. .40

FIGURE 7. SIMPLIFIED DESIGN FOR "ISLAND-2" TYPE LTA . .41

FIGURE 8. CALCULATIONAL MODEL FOR "ISLAND-2" MOX LTA SURROUNDED BY URANIUM ASSEMBLIES. $60^{\circ}$ SECTOR. .42

FIGURE 9. PINS NUMERATION IN CS MODEL .43

FIGURE 10. EVOLUTION OF KO IN PLUTONIUM-URANIUM SUPER-CELLS IN THE PROCESS OF FUEL IRRADLATION.

FIGURE 11. KK EVOLUTION IN URANIUM/PLUTONIUM SUPER-CELLS IN THE PROCESS OF FUEL IRRADIATION. .45

FIGURE 12. PARAMETRIC STUDIES OF «ISLAND» TYPE MOX LTA (U 3.7\%)...........................46

FIGURE 13. PARAMETRIC STUDIES OF «ISLAND» TYPE MOX LTA (U 4.4\%).............................47

FIGURE 14. SIMPLIFIED DESIGN FOR "INCREASED ISLAND-2" TYPE MOX LTA ................48

FIGURE 15 . KK AGAINST "ISLAND" PERIPHERY ENRICHMENT FOR DIFFERENT "ISLAND" SIZE. "ISLAND" CENTRAL ENRICHMENT - 4.0\%, URANIUM ENRICHMENT - 3.7\% .

FIGURE 16. KK AGAINST "ISLAND" PERIPHERY ENRICHMENT FOR DIFFERENT "ISLAND" SIZE. "ISLAND" CENTRAL ENRICHMENT - 4.0\%, URANIUM ENRICHMENT - 4.4\% . 
RUSSIAN RESEARCH CENTER KURCHATOV INSTITUTE

Results of Parametric Design Studies of MOX Lead Test Assembly (Final Report for FY98)

FIGURE 17. INTER-PIN RELATIVE BURNUP DISTRIBUTION..........................................50

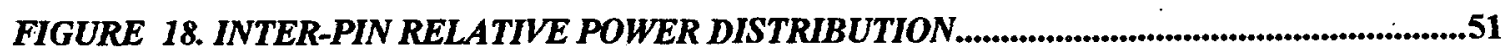

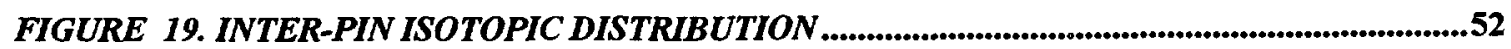

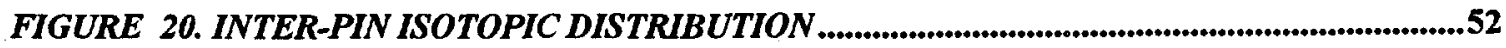

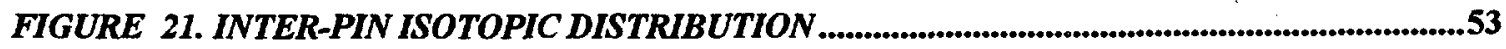

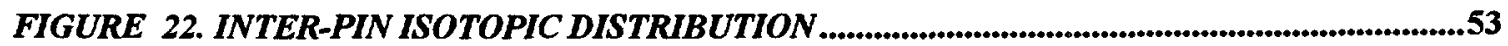

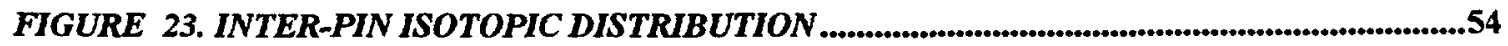

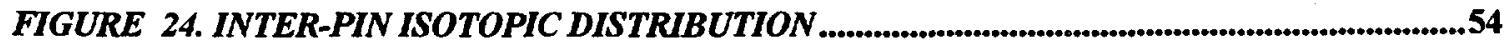

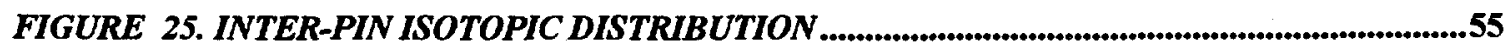

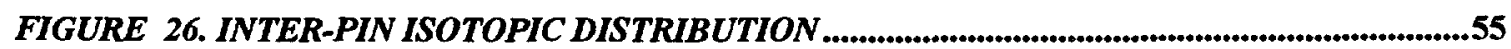

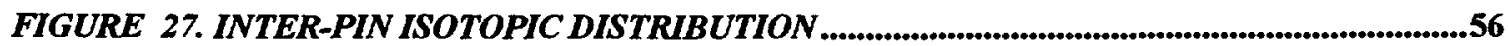

FIGURE 28. INTER-PIN ISOTOPIC DISTRIBUTION

FIGURE 29. SPECTRUM PARAMETERS DISTRIBUTION IN MOX ASSEMBLY (PU 3.8. SECTOR

609

FIGURE 30. SPECTRUM PARAMETERS DISTRIBUTION IN MOX ASSEMBLY (PU 3.8_3.8_U 3.7.

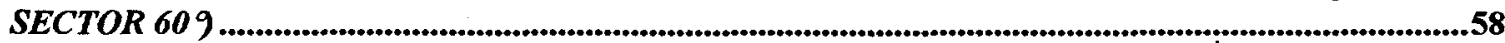

FIGURE 31. SPECTRUM PARAMETERS DISTRIBUTION IN MOX ASSEMBLY (PU 3.8_2.8_U 3.7.

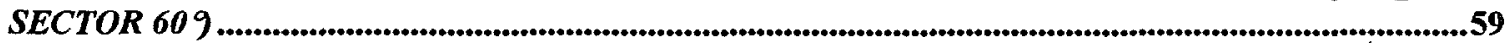

FIGURE 32. POWER DISTRIBUTION IN "ISLAND" TYPE MOXASSEMBLY PPU 3.8_2.8_U 3.7.

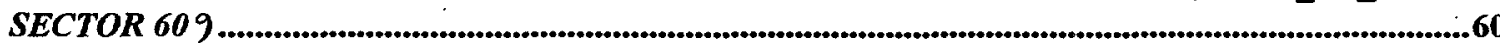

FIGURE 33. POWER DISTRIBUTION IN "ISLAND" TYPE MOX ASSEMBLY PU 3.8_2.8_U 3.7.

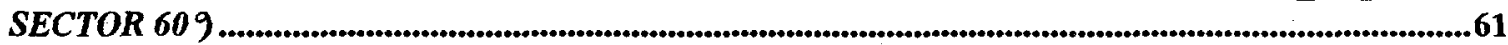

FIGURE 34. BURNUP DISTRIBUTION IN “ISLAND" TYPE MOX ASSEMBLY (PU 3.8_2.8_U 3.7.

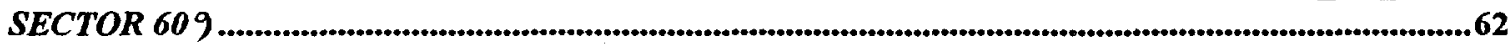

FIGURE 35. ASSEMBLY PARAMETERS EVOLUTION FOR DIFFERENT ENRICHMENT

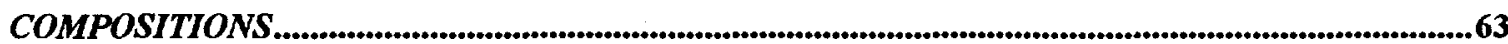

FIGURE 36. ASSEMBLY PARAMETERS EVOLUTION FOR DIFFERENT ENRICHMENT

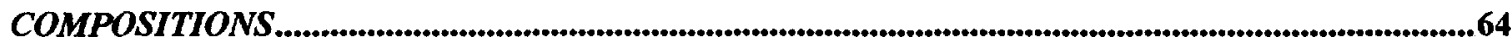

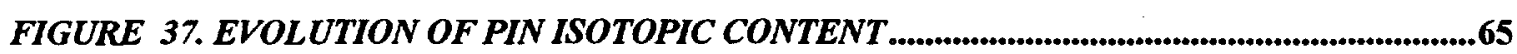

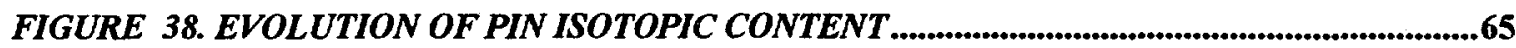

FIGURE 39. EVOLUTION OF PIN ISOTOPIC CONTENT .........................................................66 
RUSSIAN RESEARCH CENTER KURCHATOV INSTITUTE

Results of Parametric Design Studies of MOX Lead Test Assembly (Final Report for FY98)

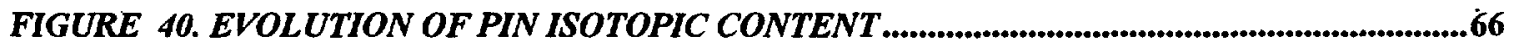

FIGURE 41. EVOLUTION OF PIN ISOTOPIC CONTENT ..........................................................67

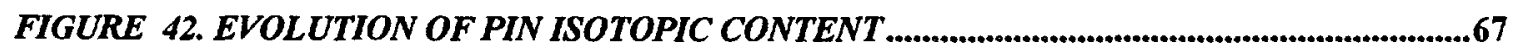




\section{INTRODUCTION}

This work is a part of Joint U.S. / Russian Project with Weapons-Grade Plutonium Disposition in VVER Reactor and presents the results obtained in the process of parametric studies of MOX LTA design.

The volume and sequence of these studies have been defined in [2] as the stage "Assembly". This report completes the studies partially executed in [3].

At the stage "Assembly" two options of infinite grid are considered:

- grid consisting of single MOX LTAs;

- grid consisting of the following elements: central MOX LTAs surrounded by typical uranium assemblies.

Parametric studies must be resulted in the following features of MOX LTA design:

- $\quad$ Proximity of power generation in MOX LTA and in replaced uranium assembly (Figure 1);

- MOX LTA zoning that ensures acceptable power peaking factor in calculational system.

Two options of MOX LTA are considered within parametric studies:

- $100 \%$ plutonium (Figure 3 );

- "Island" type (Figure 5, 7).

The Russian cell code TVS-M [3] is used as a calculational instrument. Its main features are evoked in Chapter 2.

In Chapter 3 the calculational model is described.

The results obtained for $100 \%$ plutonium option of MOX LTA are presented in Chapter 4, for "island" type option - in Chapter 5.

In the Annex the studies executed in IPPE are presented.

\section{Definitions}

In the following table the parameters used in current studies are described according to [2]. 
RUSSIAN RESEARCH CENTER KURCHATOV INSTITUTE

Results of Parametric Design Studies of MOX Lead Test Assembly (Final Report for FY98)

\begin{tabular}{|c|c|c|c|}
\hline Parameter & $\begin{array}{l}\text { Abbre } \\
\text { viation }\end{array}$ & Units & Remarks \\
\hline Calculational system & $\mathrm{CS}$ & & Infinite grid \\
\hline Reactivity of CS & RO & $\mathrm{pcm}$ & $\mathrm{RO}=(\mathrm{Keff}-1) / \mathrm{Keff}^{*} 1 . \mathrm{E} 5$ \\
\hline $\begin{array}{l}\text { Effective multiplication } \\
\text { factor of CS }\end{array}$ & Keff & & \\
\hline $\begin{array}{l}\text { Multiplication factor of a } \\
\text { central assembly in CS }\end{array}$ & Ko & & $\begin{array}{l}\text { Relation of neutron generation } \\
\text { to neutron absorption. }\end{array}$ \\
\hline $\begin{array}{l}\text { Average Boron acid } \\
(\mathrm{H} 3 \mathrm{BO} 3) \text { concentration }^{\mathrm{a}} \text { in } \\
\text { coolant }\end{array}$ & $\mathrm{Cb}$ & ppm & $\begin{array}{l}\mathrm{H} 3 \mathrm{BO} 3 \text { fraction in coolant (mg } \\
\text { of boron acid in } 1 \mathrm{Kg} \text { of } \mathrm{H} 2 \mathrm{O} \text { ) }\end{array}$ \\
\hline $\begin{array}{c}\text { Critical boron acid } \\
\text { concentration in coolant }\end{array}$ & $\mathrm{Cb}$ crit & $\mathrm{ppm}$ & $\mathrm{Cb}$ value ensuring $\mathrm{Keff}=1$ \\
\hline $\begin{array}{l}\text { 2-D power distribution in } \\
\mathrm{CS}\end{array}$ & Kk-CS & & $\begin{array}{l}\text { Power of fuel pins normalized } \\
\text { by average fuel pin power in CS. }\end{array}$ \\
\hline $\begin{array}{l}\text { Peaking factor of 2-D } \\
\text { power distribution in } \mathrm{CS}\end{array}$ & $\begin{array}{l}\text { Kkmax- } \\
\text { CS }\end{array}$ & & Maximum in $\mathrm{Kk}-\mathrm{CS}$ values \\
\hline $\begin{array}{l}\text { 2-D power distribution in } \\
\text { assembly }\end{array}$ & $\mathrm{Kk}$ & & $\begin{array}{l}\text { Power of fuel pins normalized } \\
\text { by average fuel pin power in } \\
\text { assembly. }\end{array}$ \\
\hline $\begin{array}{l}\text { 2-D power peaking factor in } \\
\text { assembly }\end{array}$ & $(\mathrm{Kk}) \max$ & & $\begin{array}{l}\text { Maximum relative power of fuel } \\
\text { pins (maximum of Kk values) }\end{array}$ \\
\hline $\begin{array}{l}\text { 1-D burnup distribution in } \\
\text { fuel pin }\end{array}$ & BUpin & & $\begin{array}{l}\text { Burnup distribution in } \\
\text { concentric zones of equal volume } \\
\text { in fuel pin, normalized by average } \\
\text { zone burnup. }\end{array}$ \\
\hline
\end{tabular}

\footnotetext{
${ }^{a}$ Boron acid concentration divided by the coefficient 5.72 means natural boron (nat B) concentration. In VVER-1000 calculations the term of boron acid concentration is widely used. Below, $\mathrm{Cb}$ means boron acid concentration if there is no special indication.
} 
RUSSIAN RESEARCH CENTER KURCHATOV INSTITUTE

Results of Parametric Design Studies of MOX Lead Test Assembly (Final Report for FY98)

\begin{tabular}{|c|c|c|c|}
\hline $\begin{array}{l}\text { 1-D power distribution in } \\
\text { fuel pin }\end{array}$ & qpin & & $\begin{array}{l}\text { Power distribution in concentric } \\
\text { zones of equal volume in fuel pin, } \\
\text { normalized by average zone power. }\end{array}$ \\
\hline $\begin{array}{l}\text { Fission cross section for } \\
\text { fast neutrons }\end{array}$ & $\Sigma_{f}^{\text {fast }}$ & $\mathrm{cm}^{-1}$ & ד \\
\hline $\begin{array}{l}\text { Fission cross section for } \\
\text { thermal neutrons }\end{array}$ & $\Sigma_{f}^{\text {th }}$ & $\mathrm{cm}^{-1}$ & \\
\hline $\begin{array}{l}\text { Absorption cross section for } \\
\text { fast neutrons }\end{array}$ & $\Sigma_{\mathrm{a}}^{\text {fast }}$ & $\mathrm{cm}^{-1}$ & \\
\hline $\begin{array}{l}\text { Absorption cross section for } \\
\text { thermal neutrons }\end{array}$ & $\Sigma_{a}^{\text {th }}$ & $\mathrm{cm}^{-1}$ & \\
\hline Fast neutron flux & $\mathrm{F}_{1}$ & & \\
\hline Thermal neutron flux & $\mathrm{F}_{2}$ & & \\
\hline $\begin{array}{l}\text { Effective fraction of } \\
\text { delayed neutrons }\end{array}$ & $\beta$ eff & & $\begin{array}{l}\text { General characteristic of infinite } \\
\text { grid }\end{array}$ \\
\hline $\begin{array}{l}\text { Specific reactor thermal } \\
\text { power in } \mathrm{CS}\end{array}$ & Wv & $\begin{array}{l}\mathrm{kW} / \\
\text { litre }\end{array}$ & $\begin{array}{l}\text { Reactor thermal power in CS } \\
\text { volume unit. For nominal } \\
\text { conditions } W v=108 \mathrm{KBt} / \text { litre. }\end{array}$ \\
\hline $\begin{array}{l}\text { Minimum controllable level } \\
\text { of reactor power }\end{array}$ & MCL & MW & $\begin{array}{l}\text { In calculations corresponds to } \\
\text { Zero Power and uniform } \\
\text { temperature } 280^{\circ} \mathrm{C} \text { in core. }\end{array}$ \\
\hline $\begin{array}{l}\text { Average coolant-moderator } \\
\text { temperature in } \mathrm{CS}\end{array}$ & $T$ mod & ${ }^{\circ} \mathrm{C}$ & \\
\hline $\begin{array}{l}\text { Average fuel temperature in } \\
\mathrm{CS}\end{array}$ & T fuel & ${ }^{\circ} \mathrm{K}$ & \\
\hline $\begin{array}{l}\text { Average temperature of } \\
\text { other CS components }\end{array}$ & $\mathrm{T}$ con & ${ }^{\circ} \mathrm{C}$ & \\
\hline $\begin{array}{l}\text { Xenon-135 concentration } \\
\text { distribution }\end{array}$ & $\mathrm{Xe}$ & $\begin{array}{l}10 * 24 \\
/ \mathrm{cc}\end{array}$ & For $1 \mathrm{cc}$ in fuel \\
\hline
\end{tabular}




\begin{tabular}{|c|c|c|c|}
\hline $\begin{array}{c}\text { Equilibrium Xenon-135 } \\
\text { concentration distribution }\end{array}$ & $\begin{array}{c}\text { Xe eq } \\
(\mathrm{Wv})\end{array}$ & \multicolumn{1}{|c|}{$10^{*} 24$} & $\begin{array}{c}\text { Concentration formed during } \\
\text { long working with a constant WV. }\end{array}$ \\
\hline $\begin{array}{c}\text { Sm-149 concentration } \\
\text { distribution }\end{array}$ & $\mathrm{Sm}$ & $10^{*} 24$ & For l cc in fuel \\
\hline $\begin{array}{c}\text { Equilibrium Sm-149 } \\
\text { concentration distribution }\end{array}$ & $\mathrm{Sm} \mathrm{eq}$ & \multicolumn{1}{|cc}{$10^{*} 24$} & $\begin{array}{l}\text { Concentration formed during } \\
\text { long working with constant } \\
\text { parameters }\end{array}$ \\
\hline
\end{tabular}




\section{Short Description of TVS-M}

TVS-M is the spectral code for calculations of neutronic constants of cells, super-cells and fuel assemblies of VVER-type reactors. It is a component of code package for VVERs calculations.

A constants library used by TVS-M has the following main features:

- in the fast energy region $\left(\mathrm{E}_{n}>4.65 \mathrm{KeV}\right)$ multigroup cross-sections library ABBN is applied. This energy range includes 12 groups of the library. In parallel with the nuclides group constants the subgroup ones are used.

- resonance energy range $\left(4.65 \mathrm{KeV}>\mathrm{E}_{n}>0.625 \mathrm{eV}\right)$ includes the $A B B N$ groups from 13-th to 24-th ( the cross-sections of 24-th group are modified, because the lower boundary of this group is not coincident with the one of the ABBN library). In this energy range the TVS-M code also uses both subgroup and group constants. Besides, the files of resonance parameters from LIPAR-3 library are applied for resonance nuclides. For the most of these nuclides the crosssection calculation is based on the Breit-Wigner multi-level model (and on the Adler-Adler model for fissile nuclides ).

- thermal energy range $\left(E_{n}<0.625 \mathrm{eV}\right.$ ) is subdivided into 24 groups. A set of scattering matrices calculated for various temperatures by the Koppel-Young model is applied for hydrogen bonded in a water molecule. Group cross-sections of nuclides and the scattering matrixes have been obtained with the use of the same algorithms and nuclear data (TEPCON library) as in case of MCU-RFFI/A code.

- 96 fission products are taken into account under burnup calculation. TVS$M$ code uses library of their yields based on ENDF/B-VI data and group crosssections from MCU data library.

TVS-M calculation technique consists of the following main stages :

- firstly a detailed calculation of all cell types forming a fuel assembly (such as fuel cell, absorber cell and so on ) is performed and corresponding sets of fewgroup constants are computed ( number of the groups is arbitrary)

- then these group effective constants are used in a group nodal diffusion calculation of the whole assembly.

Computing of neutrons spatial distribution in specified energy group (or at specified energy point) is performed by the method of passing through probability (similar to first collision probability method). At the present time an angular distribution of the onedirection neutrons current at a given zone boundary is described by 6 angular harmonics. A neutrons reflection at a cell boundary takes into account a real hexagonal form of the boundary. For a calculation of an effective diffusion coefficient both isotropic and anisotropic probabilities in $\mathrm{R}$ and $\mathrm{Z}$ directions are computed in the same manner. 
In the fast energy region a detailed calculation is carried out with the use of group and subgroup micro cross-sections from the $\mathrm{ABBN}$ library. In doing so each energy group is subdivided into arbitrary number of intervals of uniform width. The energy loss of a neutron on non-elastic slowing down is described by continuous function specified by the group matrix of non-elastic transfers. The neutron energy loss on elastic slowing down is also described continuously with taking into account of scattering anisotropy in a system of inertia centre.

In the resonance region the slowing down of neutrons is calculated in the same manner as in the case of fast energy region. Cross-sections of resonance nuclides at each energy point are calculated with the CROSS code using the file of resonance parameters for each nuclide. An interference between potential and resonance scattering, cross-sections temperature dependence, $\mathrm{p}$-wave contribution into scattering cross-section are strictly taken into consideration. An effect of mutual overlapping of different nuclides resonances is also taken into account.

A calculation technique applied in thermal energy region is traditional. The group thermalization equation is solved by the method of passing through probability. The sources are shaped when the upper energy groups are calculated, with the Nelkine asymptotic limit of scattering applied for hydrogen.

Nodal diffusion approach with asymptotic and transient trial functions (both for flux and current ) is applied for pin-by-pin calculation of fuel assembly. The asymptotic solution corresponds to the problem with a non-zero source (slowing down or fission) and zero current at the cell boundary. The transient trial function corresponds to the problem on finding neutron distribution in the cell placed at the center of super-cell when a source in it is equal to zero. And in such super-cell a fuel cell is surrounded by the water and a cell of the other type - by homogenized fuel cells. A correction for mesh width is also involved in the balance equation. This correction takes into account the difference between an average flux and a flux at the cell boundary. The similar correction for a current flowed through the cell also appears in the balance equation.

The burnup equations are solved for every fuel pin, which can be subdivided into several concentric rings forming separate burnup zones. Concentration changing of the following heavy nuclides is taken into consideration:

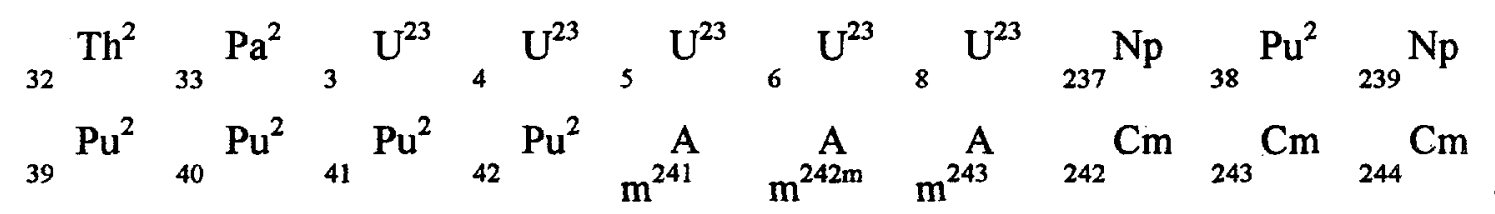

Equilibrium concentrations of $\mathrm{Xe}^{135}$ and $\mathrm{Sm}^{149}$ are also calculated.

\section{Calculational Model}

Calculational system (CS) for MOX LTA design parametric studies is presented by two principal options:

- infinite grid of single plutonium or uranium assemblies (Fig. ); 
- infinite grid of central plutonium assemblies surrounded by uranium assemblies of $3.7 \% \mathrm{Wt}$. U-235. The $60^{\circ}$ sector of CS for different options of MOX LTA design is shown in Figures 4, 6 and 8. The reference uranium CS is shown in Figure 2.

Composition of weapons grade plutonium is presented in Table 1 . The design parameters of plutonium and uranium assemblies are described in Tables 2-5.

The calculational model includes the following two principal regimes described below.

\subsection{Fuel Irradiation Simulation}

This regime is used for MOX LTA zoning studies under the conditions described in [2]. They comprise irradiation simulation in CS as a rule on the interval [0-40 MWd/kg] with the step $2 \mathrm{MWd} / \mathrm{kg}$.

In the process of irradiation:

- Axial buckling is $1 . \mathrm{E}-4 \mathrm{~cm}-2$. A set of calculations has been executed with a critical buckling ensuring $\mathrm{Keff}=1$;

- $\quad \mathrm{Cb}($ nat $\mathrm{B})=600 \mathrm{ppm}$;

- $\quad W v=108 \mathrm{KW} / \mathrm{litre}$;

- $\quad T \bmod =302^{\circ} \mathrm{C}$,

- $\quad \mathrm{T}$ con $=302^{\circ} \mathrm{C}$;

- $\quad$ Tfuel $=1027^{\circ} \mathrm{K}$;

- $\quad X e=X e$ eq;

- $\quad \mathrm{Sm}=\mathrm{Sm}$ eq

\subsection{Zero Power Calculations}

This regime is aimed to define reactivity effects due to temperature and $\mathrm{Cb}$ variations and to compare Keff with eventual verification calculations to be carried out by other codes.

Calculations are executed in five irradiation points:

$0,10,20,30,40 \mathrm{GWd} / \mathrm{t}$

where states are to be formed by different combinations of the following values:

$\mathrm{Cb}$ (nat.B): 0, 600,1200 ppm;

Tmod $=$ Tcon $=$ Tfuel: $20,280^{\circ} \mathrm{C}$.

\section{Calculations of $100 \%$ Plutonium MOX LTA}

\subsection{Zoning Parametric Studies}

Zoning parametric studies consisted in variation of fissile plutonium content in 3zones MOX LTA (Figure 3).

The results of calculations simulating fuel irradiation in plutonium and uranium assemblies are presented in Tables 7-13. Two options of Uranium reference assembly are considered:

- without BPR i.d. with guide tubes filled by water in 18 positions in assembly (see Figure 1); 
- $\quad$ with BPRs of properties presented in Table 6.

It can be seen that $2 \%$ fissile plutonium content in periphery (it is the minimum allowable value according to [2]) entails significantly lower values of power peaking factor "Kkmax-CS" than $2.4 \%$ content (compare Tables 10 and 11 ). That is why $2 \%$ content in periphery has been adopted. Plutonium content in the central and intermediate zones was variable to obtain Ko value similar to reference uranium CS.

Finally the plutonium content of $4.2 / 3.0 / 2.0$ has been chosen as acceptable. The Ko evolution in the process of fuel irradiation for the reference uranium and different plutonium assemblies is shown in Figure 10.

Figure 11 shows "Kkmax-CS" evolution in the process of irradiation. The increase of "Kkmax-CS" for 3-zones MOX LTAs is observed from a certain moment. As it is seen from the Table 13 and Figure 9, during irradiation maximum CS power passes from uranium pins out of MOX LTA to the interior of MOX LTA. This effect should be studied in future more attentively taking into account that in real conditions a fresh MOX LTA will be surrounded by both fresh and irradiated uranium assemblies that can lead to mitigating of the mentioned effect.

It is evident that the described procedure of preliminary studies of CS serves only for estimation of eventual performance of MOX LTA in core and that real performance of MOX LTA in core will depend on its real location there. It is quite possible that we should return to the stage "Assembly" after core calculations.

\subsection{Zero Power Calculations}

The results of calculations are presented in Table 7 . It may be seen that the positive temperature reactivity effect appears for the great boron concentrations of $1200 \mathrm{ppm}$. In MOX LTA this effect is lower owing to more absorbable properties of MOX fuel as compared with uranium one. 


\section{Calculations of "Island" Type MOX LTA}

In these calculations the size of "island" in the center of assembly has been fixed: 54 plutonium fuel pins i.e. 4 pin rows. Two options of "island" have been considered:

- one-zone island or "Island-1"(Figure 5);

- two-zones island or "Island-2"(Figure 7).

The studies are divided into three parts:

- $\quad$ studies of infinite grid of fresh MOX LTA by means of plutonium content variation to ensure acceptable value of power peaking factor $\mathrm{Kk}$. Axial buckling in this case was variable to provide $\mathrm{Keff}=1$.

- calculation of CS, where MOX LTA is surrounded by uranium assemblies, for zoning option chosen in the previous part. In this part plutonium/uranium fuel irradiation has been simulated.

- studies of infinite grid of plutonium assemblies for zoning option chosen in the first part. Axial buckling in this case was variable to provide $\mathrm{Keff}=1$. In this part plutonium/uranium fuel irradiation has been simulated. Inter-pin isotopic and power distributions have been calculated.

The comparison of different spectrum parameters has been also made for a number of combinations of uranium and plutonium fuel enrichments.

Two levels of acceptable values of power peaking factor $\mathrm{Kk}$ have been considered:

$$
\begin{aligned}
& \text { - } \quad \mathrm{Kk}=1.20 \\
& \text { - } \quad \mathrm{Kk}=1.15
\end{aligned}
$$

This rather high value of $\mathrm{Kk}=1.20$ was considered in the hope that a proper choice of MOX LTA location in core could lead to rather low power values qi in MOX LTA and finally to an acceptable value of $\mathrm{qi}^{*} \mathrm{Kk}$ according to safety limits $[1,2]$.

Uranium zone enrichment inside MOX LTA was equal to $3.7 \%$ as a base. In some calculations the option of $4.4 \%$ has been also considered.

\section{1. "Island-1" option}

The studies for uranium zone enrichment of $3.7 \%$ have shown (Figure 12) that fissile plutonium content in plutonium zone cannot exceed:

- $2.4 \%$ if $\mathrm{Kk}$ maximum is 1.15 ;

- $2.7 \%$ if $\mathrm{Kk}$ maximum is 1.20 .

These values are too low to justify practical using of "Island-1" option in this case. 
RUSSIAN RESEARCH CENTER KURCHATOV INSTITUTE

Results of Parametric Design Studies of MOX Lead Test Assembly (Final Report for FY98)

For uranium zone enrichment of $4.4 \%$, fissile plutonium content in plutonium zone cannot exceed (Figure 13):

- $3.0 \%$ if $\mathrm{Kk}$ maximum is 1.15

- $3.4 \%$ if $\mathrm{Kk}$ maximum is 1.20 .

\section{2. "Island-2" option}

Results of parametric calculations of "Island-2" option have allowed to obtain the pares of plutonium content values in two plutonium zones which could ensure the acceptable value of $\mathrm{Kk}$. The Figures 12 and 13 (correspondingly for uranium zone enrichment of $3.7 \%$ and of $4.4 \%$ ) allow to choose fissile plutonium content ensuring optimum (i.e. minimum) $\mathrm{Kk}$ values.

Finally, the chosen zoning is the pair " $3.8 \%$ in the central part $-2.8 \%$ in the island periphery" with uranium environment of $3.7 \%$. In this case, the acceptable power peaking factor, as well as Ko values, close to the reference uranium $\mathrm{CS}$, have been ensured according to Figures 12 and 10.

\section{3 "Plutonium island" size variation}

Increased size of "Plutonium Island" that comprises 6 plutonium rows (Fig. 14) has been also considered. In Fig. 15 and 16 the central plutonium enrichment has been fixed by $4 \%$ while considering two uranium environment enrichments: $3.7 \%$ and $4 \%$. The Figures 15 and 16 shows an optimum plutonium periphery enrichment about $3 \%$ where $\mathrm{Kk}$ minimum is reached.

\subsection{Inter-pin isotopic content and power distribution}

Inter-pin isotopic content and power distributions are of interest for thermo-hydraulic analysis of MOX fuel behavior. TVS-M allows obtaining of these parameters for 5 concentric zones that have been chosen of equal volumes in current calculations. In Fig. 17-28 they are presented for some character pins:

- near central instrumentation tube (as No 77 in Fig.31),

- near water tube (as No 76 in Fig. 31),

- on the border of different "island" enrichments (as No 75 in Fig. 31),

- on the "island" periphery (as No 74 in Fig. 31),

- in uranium fuel pin (as No 72 in Fig. 31). 
The following moments while fuel burning have been considered: 12 and $40 \mathrm{MWd} / \mathrm{kg}$ that corresponds approximately to fuel discharged after one and three years of reactor exploitation.

Figures 17 and 18 show correspondingly inter-pin relative burnup and power distributions $\mathrm{BU}_{\mathrm{pin}}$ and $\mathrm{q}_{\text {pin. }}$. Figures 19-28 show correspondingly inter-pin distribution of $\mathrm{U}_{235}, \mathrm{PU}_{239}, \mathrm{PU}_{240}, \mathrm{PU}_{241}, \mathrm{PU}_{242}$ for two irradiation levels: 12 and $40 \mathrm{MWd} / \mathrm{kg}$.

\subsection{Spectrum characteristics analysis}

Usually, more reliable results of treatment of experimental data on fuel pin burning can be obtained if fuel irradiation takes place in the neutron spectrum close to the asymptotic one. It can be seen in Figures 29-31 that in two internal rows of plutonium island " $3.8 \%$ in the central part $-2.8 \%$ in the island periphery" the spectrum is close to the one taking place in $100 \%$ Plutonium MOX LTA with the enrichment of $3.8 \%$. So fuel fins located in these positions is reasonable to use for plutonium fuel investigation in the case of "Island" type MOX LTA design.

Relative power distributions are shown in Figures 32 and 33 for the following moments while fuel burning $0,12,24$ and $40 \mathrm{MWd} / \mathrm{kg}$.

Relative burnup distributions are shown in Fig.34 for the following moments while fuel burning 12,24 and $40 \mathrm{MWd} / \mathrm{kg}$.

Evolution of average assembly neutron absorption and fission cross-sections while fuel burning is presented in Fig. 35 for a number of plutonium and uranium enrichment compositions.

Evolution of multiplication factor Ko and power peaking factor $\mathrm{Kk}$ while fuel burning is presented in Fig.36 for a number of plutonium and uranium enrichment compositions.

In Figures 37-42 the evolution of $\mathrm{U}_{235}, \mathrm{PU}_{239}, \mathrm{PU}_{240}, \mathrm{PU}_{241}, \mathrm{PU}_{242}$ and $\mathrm{Am}_{241}$ content while fuel burning is presented for a number of plutonium and uranium enrichment compositions. 


\section{CONCLUSION}

The parametric studies of MOX LTA design have been executed to choose plutonium content in assembly zones for two options of MOX LTA: "3-zones" and "Island".

For "3-zones" (100\% Plutonium) MOX LTA the fissile plutonium content composition of $4.2 \% / 3,0 \% / 2 \%$ has been chosen.

MOX LTA of the chosen compositions has been studied by using multi-assembly configuration that allows investigating of influence of MOX LTA environment: uranium assemblies of different irradiation.

Plutonium "Island" with 54 plutonium pins in the center of MOX LTA has been considered in two modifications:

- uniform "island";

- graded "island" with lower plutonium content in one peripheral row of pins.

It is shown that plutonium content in the uniform "island" cannot exceed $2.7 \%$ because of adopted power peaking limitations and therefore this design seems unreasonable for practical use.

For graded "island" the plutonium content composition 3.8\%/2.8\% with uranium environment of $3.7 \%$ U-235 has been chosen.

Evolution of assembly power and burnup distributions, inter-pin power and isotopic distributions while fuel irradiating have been analyzed.

In addition to the base uranium environment of $3,7 \%$, a set of calculations has been executed for $4.4 \%$.

The most of the studies has been executed by the code TVS-M that is at the final stage of licensing and it is to be used in the nearest future as a base instrument for VVER core calculations while using both uranium and MOX fuel. So the obtained results must be considered as preliminary ones and they demand additional analysis and investigations. 


\section{REFERENCES}

1. Y.A. Styrin. Fuel Assembly and Core Model for Neutronics Calculations of VVER-1000. Draft.

Moscow, Kurchatov Institute 1998.

2. Y.A. Styrin, I.K.Levina. Design of Lead Test MOX Assemblies for Pilot Irradiation in VVER-1000 and Related Parametric Studies. Draft.

Moscow, Kurchatov Institute 1998.

3. S.A. Bichkov, A.P.Lazarenko, V.D.Sidorenko, Y.A. Styrin. Results of Parametric Design Studies of MOX Lead Test Assembly (Progress Report).

Moscow, Kurchatov Institute 1998.

4. V.D.Sidorenko et al. Spectral Code TBC-M for calculation of Characteristics of Cells, Super-cells and Fuel Assemblies of VVER-Type Reactors. 5th Symposium of the AER. 
RUSSIAN RESEARCH CENTER KURCHATOV INSTITUTE

Results of Parametric Design Studies of MOX Lead Test Assembly (Final Report for FY98)

Table 1. Composition of weapons grade plutonium

\begin{tabular}{|l|l|l|l|l|}
\hline Isotope / content (Wt \%) \\
\hline $\mathrm{Pu}-238$ & $\mathrm{Pu}-239$ & $\mathrm{Pu}-240$ & $\mathrm{Pu}-241$ & $\mathrm{Pu}-242$ \\
\hline 0.0 & 93.0 & 6.0 & 1.0 & 0.0 \\
\hline
\end{tabular}


RUSSIAN RESEARCH CENTER KURCHATOV INSTITUTE Results of Parametric Design Studies of MOX Lead Test Assembly (Final Report for FY98)

Table 2. Main Core Parameters

\begin{tabular}{|l|l|l|}
\hline Parameter & Units & Value \\
\hline Thermal Power & & \\
\hline Electrical Power & $\begin{array}{l}\text { MW } \\
\text { thermal }\end{array}$ & 3000 \\
\hline Number of Coolant Loops & $\mathrm{MW}$ & $\mathbf{1 0 0 0}$ \\
\hline Number of Fuel Assemblies & & 4 \\
\hline Core Equivalent Diameter & & 163 \\
\hline Core Fuel Height & $\mathrm{m}$ & 3.164 \\
\hline Core Volume & $\mathrm{m}$ & 3.53 \\
\hline Core Power Density & $\mathrm{m}^{3}$ & 27.8 \\
\hline Control / Shut off Rod Banks & $\mathrm{W} / \mathrm{cm}^{3}$ & 108 \\
\hline Position of Regulating Rod Bank & & 10 \\
\hline Core Coolant Flow Rate & $\%$ & 90 \\
\hline Pressure at Core Inlet & $\mathrm{m}^{\mathrm{s}} / \mathrm{hr}$ & 84000 \\
\hline Core Inlet Temperature & $\mathrm{MPa}$ & 15.7 \\
\hline
\end{tabular}


Table 3. Fuel Assembly Design Parameters

\begin{tabular}{|c|c|c|}
\hline Parameter & Units & Value \\
\hline Shape of Fuel Assembly & & Hexagonal \\
\hline Distance Across Assembly (between flats) & $\mathbf{c m}$ & 23.4 \\
\hline Distance Between Fuel Assembly Centres & $\mathbf{c m}$ & 23.6 \\
\hline Fuel Pin Lattice Pitch & $\mathbf{c m}$ & 1.275 \\
\hline Number of Fuel Pins in Fuel Assembly & & 312 \\
\hline $\begin{array}{l}\text { Number of Guide Tubes for Control Rods } / \\
\text { Burnable Absorber Pins }\end{array}$ & & 18 \\
\hline Inner Diameter of Guide Thimbles & $\mathbf{c m}$ & 1.1 \\
\hline Thickness of Guide Thimbles & $\mathbf{c m}$ & 0.1 \\
\hline Material of Guide Thimbles & & Zirconium Alloy* \\
\hline $\begin{array}{l}\begin{array}{l}\text { Central Instrumentation } \\
\text { Diameter }\end{array} \\
\end{array}$ & $\mathbf{c m}$ & 1.1 \\
\hline Thickness of Central Instrumentation Tube & $\mathbf{c m}$ & 0.1 \\
\hline Material of Central Guide Tube & & Zirconium Alloy * \\
\hline Number of Spacer Grids in Fuel Assembly & & 13 \\
\hline Material of Spacer Grids & & Zirconium Alloy* \\
\hline Spacer Grid Weight (each) & $\mathbf{K g}$ & 0.55 \\
\hline \multicolumn{2}{|l|}{ Compositions Weight percent: } & $\cdot$ \\
\hline \begin{tabular}{|l|l|} 
& $\mathbf{N b}$ \\
\end{tabular} & & \\
\hline 98.97 & & \\
\hline
\end{tabular}


RUSSIAN RESEARCH CENTER KURCHATOV INSTITUTE

Results of Parametric Design Studies of MOX Lead Test Assembly (Final Report for FY98)

Table 4. Uranium Fuel Pin Design Parameters

\begin{tabular}{|l|l|l|}
\hline Parameter & Units & Value \\
\hline & & Advanced Core Design \\
\hline Inner Clad Diameter & $\mathrm{cm}$ & 0.772 \\
\hline Clad Thickness & $\mathrm{cm}$ & 0.069 \\
\hline Clad Material & & Zirconium Alloy ${ }^{*}$ \\
\hline Clad Density & $\mathrm{g} / \mathrm{cc}$ & 6.5153 \\
\hline Fuel Pellet Diameter & $\mathrm{cm}$ & 0.755 \\
\hline Central Hole Diameter & $\mathrm{cm}$ & 0.15 \\
\hline Fuel Pellet Material & & L.E. UO2 \\
\hline Height of Fuel Column & $\mathrm{cm}$ & $\begin{array}{l}353 \text { (cold) } \\
355 \text { (hot) }\end{array}$ \\
\hline Mass of UO2 in Fuel Pin & & 1.575 \\
\hline
\end{tabular}

Compositions Weight percent:

*

\begin{tabular}{|l|l|l|}
\hline $\mathrm{Zr}$ & $\mathrm{Nb}$ & Hf \\
\hline 98.97 & 1.0 & 0.03 \\
\hline
\end{tabular}


RUSSIAN RESEARCH CENTER KURCHATOV INSTITUTE

Results of Parametric Design Studies of MOX Lead Test Assembly (Final Report for FY98)

Table 5. MOX fuel Pin Design Parameters

\begin{tabular}{|l|c|c|}
\hline Parameter & Units & Value \\
\hline Inner Clad Diameter & $\mathrm{cm}$ & 0.772 \\
\hline Clad Thickness & $\mathrm{cm}$ & $\mathbf{0 . 0 6 9}$ \\
\hline Clad Material & & Zirconium Alloy* \\
\hline Clad Density & $\mathrm{g} / \mathrm{cc}$ & $\mathbf{6 . 5 1 5 3}$ \\
\hline Fuel Pellet Diameter & $\mathrm{cm}$ & $\mathbf{0 . 7 5 5}$ \\
\hline Central Hole Diameter & $\mathrm{cm}$ & $\mathbf{0 . 1 5}$ \\
\hline U-235 content in MOX fuel & $\%$ & 0.2 \\
\hline Fuel Pellet Material & & PuO2-UO2 \\
\hline Height of Fuel Column & $\mathrm{cm}$ & 353 (cold) \\
& & 355 (hot) \\
\hline Fuel Density & $\mathrm{g} / \mathrm{cc}$ & 10.5 \\
\hline
\end{tabular}

Compositions Weight percent:

\begin{tabular}{|c|c|c|}
\hline $\mathbf{Z r}$ & $\mathbf{N b}$ & Hf \\
\hline 98.97 & 1.0 & 0.03 \\
\hline
\end{tabular}


RUSSIAN RESEARCH CENTER KURCHATOV INSTTTUTE

Results of Parametric Design Studies of MOX Lead Test Assembly (Final Report for FY98)

'Table 6. Discrete Burnable Poison Pin Design Parameters

\begin{tabular}{|l|c|c|}
\hline Parameter & Units & Value \\
\hline Clad Inner Diameter & $\mathrm{cm}$ & 0.772 \\
\hline Clad Thickness & $\mathrm{cm}$ & 0.069 \\
\hline Clad Material & & Zirconium Alloy \\
\hline Clad Density & $\mathrm{g} / \mathrm{cc}$ & 6.5153 \\
\hline Absorber Diameter & $\mathrm{cm}$ & 0.758 \\
\hline Absorber Density & $\mathrm{g} / \mathrm{cc}$ & 2.945 \\
\hline Absorber Composition & & Boron g/cc \\
\hline & & 0.065 \\
\hline B10 & Wt $\%$ & 0.4046 \\
\hline $\mathrm{B} 11$ & & 1.8028 \\
\hline $\mathrm{Al}$ & & 88.5951 \\
\hline $\mathrm{Fe}$ & & 0.1850 \\
\hline $\mathrm{Ni}$ & & 1.8496 \\
\hline $\mathrm{Cr}$ & & 5.3133 \\
\hline $\mathrm{Zr}$ & & 1.8496 \\
\hline $\mathrm{Comp}$ & & \\
\hline
\end{tabular}

Compositions Weight percent:

\begin{tabular}{|c|c|c|}
\hline $\mathbf{Z r}$ & $\mathbf{N b}$ & Hf \\
\hline 98.97 & 1.0 & 0.03 \\
\hline
\end{tabular}


Table 7. Keff in Zero Power States

\begin{tabular}{|c|c|c|c|c|c|c|c|c|c|c|c|c|c|c|c|c|c|c|c|c|}
\hline \multirow[t]{2}{*}{$\begin{array}{l}\text { Irradiation } \\
\text { Point } \rightarrow \\
\end{array}$} & \multicolumn{4}{|c|}{ 0 } & \multicolumn{4}{|c|}{$\begin{array}{c}10, \\
\mathbf{G W d} / \mathbf{t}\end{array}$} & \multicolumn{4}{|c|}{$\begin{array}{l}\text { 20, } \\
\text { GWd/t }\end{array}$} & \multicolumn{4}{|c|}{$\begin{array}{c}\text { 30, } \\
\mathbf{G W d} / \mathbf{t} \\
\end{array}$} & \multicolumn{4}{|c|}{$\begin{array}{c}\text { 40, } \\
\text { GWd/t }\end{array}$} \\
\hline & \multicolumn{2}{|c|}{$\begin{array}{l}\text { Tmod=Tfuel } \\
=\text { Tcon } \\
=20^{\circ} \mathrm{C}\end{array}$} & \multicolumn{2}{|c|}{$\begin{array}{l}\text { Tmod=Tfuel } \\
=T \text { Tcon } \\
=280^{\circ} \mathrm{C}\end{array}$} & \multicolumn{2}{|c|}{$\begin{array}{l}\text { Tmod=Tfuel } \\
=\mathrm{Tcon} \\
=20^{\circ} \mathrm{C}\end{array}$} & \multicolumn{2}{|c|}{$\begin{array}{l}\text { Tmod=T fuel } \\
=\mathrm{T} \text { con } \\
=280^{\circ} \mathrm{C}\end{array}$} & \multicolumn{2}{|c|}{$\begin{array}{l}\text { Tmod=Tfuel } \\
=\text { Tcon } \\
=20^{\circ} \mathrm{C}\end{array}$} & \multicolumn{2}{|c|}{$\begin{array}{l}\text { Tmod=Tfuel } \\
=\text { =Tcon } \\
=280^{\circ} \mathrm{C}\end{array}$} & \multicolumn{2}{|c|}{$\begin{array}{l}\text { Tmod=Tfuel } \\
=\text { Tcon } \\
=20^{\circ} \mathrm{C}\end{array}$} & \multicolumn{2}{|c|}{$\begin{array}{l}\text { Tmod=T fuel } \\
=T \text { con } \\
=280^{\circ} \mathrm{C}\end{array}$} & \multicolumn{2}{|c|}{$\begin{array}{l}\text { Tmod=Tfuel } \\
=\mathrm{Tcon} \\
=20^{\circ} \mathrm{C}\end{array}$} & \multicolumn{2}{|c|}{$\begin{array}{l}\text { Tmod=Tfuel } \\
=\text { Tcon } \\
=280^{\circ} \mathrm{C}\end{array}$} \\
\hline $\begin{array}{l}\text { Pu/U } \\
\text { Content, \% } \\
\downarrow\end{array}$ & $\bullet$ & ్ㅗㅀ & 0 & స్త్ & $=$ & 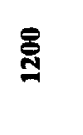 & 0 & $\stackrel{్}{\beth}$ & 0 & $\underset{\mathbb{N}}{\stackrel{9}{\dddot{N}}}$ & 0 & ్్ㅀ & 0 & ్్ㅇ & 0 & 0 & ఫ్ల్ల & $=$ & క్ష్త & ఫ్స్ \\
\hline $\begin{array}{l}\text { U: } \\
\text { 3.7/3.3 no BPR }\end{array}$ & $\stackrel{8}{\stackrel{8}{y}}$ & 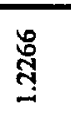 & ֻั̊ & 옥 & $\bar{c}$ & ̌ㅗㅇ & ส్ุ & 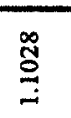 & $\stackrel{n}{\infty}$ & $\stackrel{\stackrel{m}{\sigma}}{0}$ & $\stackrel{5}{9}$ & 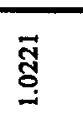 & $\begin{array}{l}0 \\
8 \\
0\end{array}$ & $\frac{ \pm}{5}$ & 융 & 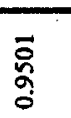 & $\frac{9}{0}$ & $\underset{\hat{8}}{\infty}$ & $\begin{array}{l}\text { 8̊ㅇ } \\
\% \\
0\end{array}$ & 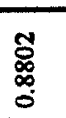 \\
\hline $\begin{array}{l}\text { U: } \\
\text { 3.7/3.3 with BPR }\end{array}$ & 象 & $\stackrel{2}{2}$ & $\stackrel{m}{\stackrel{m}{\sim}}$ & 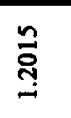 & 萬 & $\stackrel{\infty}{\stackrel{\infty}{5}}$ & 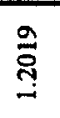 & $\underset{\infty}{0}$ & $\underset{\substack{0 \\
:}}{=}$ & 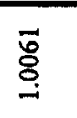 & $\underset{\Xi}{ \pm}$ & $\stackrel{m}{\stackrel{9}{\sigma}}$ & \& & 言 & $\stackrel{5}{5}$ & 苂 & $\stackrel{n}{g}$ & $\begin{array}{l}8 \\
8 \\
\infty \\
0 \\
0\end{array}$ & $\begin{array}{l}\text { 今े } \\
\text { ò } \\
0\end{array}$ & 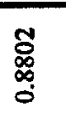 \\
\hline $\begin{array}{l}\text { PU: } \\
4.4 / 3.0 / 2.4\end{array}$ & 胥 & ঙ્ઞ & $\stackrel{\mathscr{N}}{\dddot{m}}$ & ঙุ̃ & $\stackrel{5}{9}$ & $\stackrel{8}{8}$ & 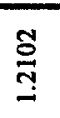 & $\stackrel{\circ}{\circ}$ & 密 & $\stackrel{\text { N}}{\sigma}$ & $\stackrel{\text { ב }}{\exists}$ & $\stackrel{\infty}{\stackrel{\infty}{0}}$ & $\begin{array}{l}\circ \\
\stackrel{8}{\circ}\end{array}$ & $\frac{ \pm}{\Delta}$ & $\stackrel{ }{\circ}$ & 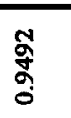 & $\underset{+}{\stackrel{ \pm}{2}}$ & 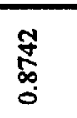 & 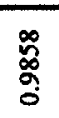 & $\begin{array}{c}\mathbb{S} \\
\stackrel{\infty}{\infty} \\
\stackrel{\infty}{0}\end{array}$ \\
\hline $\begin{array}{l}\text { PU: } \\
\text { 4.4/3.0/2.0 }\end{array}$ & 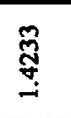 & ণู & 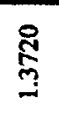 & స్త్ర & 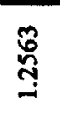 & gั & ঙ্ণ & $\begin{array}{l}30 \\
\stackrel{8}{\circ} \\
-\end{array}$ & 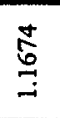 & 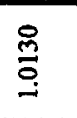 & $\underset{ت}{\stackrel{⿹}{ت}}$ & $\stackrel{E}{\sigma}$ & 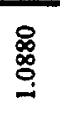 & ふั & $\stackrel{\circ}{\stackrel{\circ}{\circ}}$ & $\begin{array}{l}0 \\
\stackrel{2}{*} \\
0 \\
0\end{array}$ & $\stackrel{5}{5}$ & 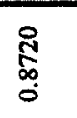 & $\begin{array}{l}\text { ఫें } \\
\text { 。 } \\
0\end{array}$ & 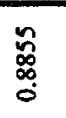 \\
\hline $\begin{array}{l}\text { PU: } \\
4.4 / 3.2 / 2.0\end{array}$ & 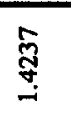 & $\overrightarrow{\nexists ్}$ & 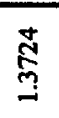 & 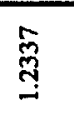 & 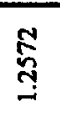 & 芯 & 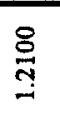 & 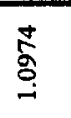 & 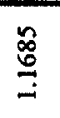 & $\underset{-}{\stackrel{J}{*}}$ & $\underset{ت}{\stackrel{9}{ \pm}}$ & $\underset{-i}{\infty}$ & 总 & $\begin{array}{l}5 \\
\text { \&े } \\
\delta\end{array}$ & 兑 & \begin{tabular}{l}
$\infty$ \\
\multirow{\infty}{\infty}{} \\
$\stackrel{0}{0}$
\end{tabular} & $\frac{8}{0}$ & $\begin{array}{l}m \\
c_{0} \\
0 \\
0\end{array}$ & $\begin{array}{l}\stackrel{\circ}{2} \\
\stackrel{\circ}{0} \\
0\end{array}$ & \begin{tabular}{l}
$\infty$ \\
\multirow{8}{\circ}{} \\
$\infty$ \\
$\infty$ \\
0 \\
0
\end{tabular} \\
\hline $\begin{array}{l}\text { PU: } \\
4.2 / 3.0 / 2.0\end{array}$ & ন্তু & 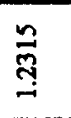 & $\underset{⿱ 乛}{\stackrel{5}{9}}$ & 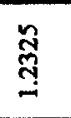 & 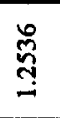 & 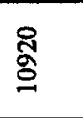 & : & $\begin{array}{l}9 \\
\text { 웅 } \\
\stackrel{-}{\circ}\end{array}$ & $\stackrel{8}{0}$ & ๕̊̊ & $\stackrel{5}{\Xi}$ & $\stackrel{\infty}{\frac{m}{\sigma}}$ & $\stackrel{5}{0}$ & 帘 & 点 & $\frac{9}{2}$ & $\underset{-i}{\stackrel{ \pm}{\sigma}}$ & $\begin{array}{l}\mathscr{0} \\
\stackrel{0}{\infty} \\
\stackrel{0}{0}\end{array}$ & 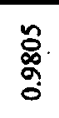 & 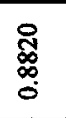 \\
\hline $\begin{array}{l}\text { PU-Island: } \\
\text { 3.8/2.8/U-3.7 }\end{array}$ & 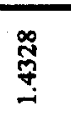 & 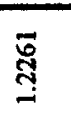 & \begin{tabular}{l}
$\overrightarrow{0}$ \\
$\stackrel{0}{0}$ \\
\hdashline
\end{tabular} & 突 & సิ స్ & స్̃ & 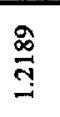 & $\begin{array}{l}\stackrel{\circ}{\circ} \\
\stackrel{-}{\circ}\end{array}$ & $\stackrel{\infty}{=}$ & $\underset{ }{\circ}$ & 壱 & $\stackrel{\Omega}{\stackrel{\sigma}{0}}$ & $\stackrel{ \pm}{g}$ & 志 & 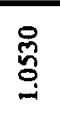 & $\begin{array}{l}\frac{1}{5} \\
3 \\
0\end{array}$ & $\underset{n}{n}$ & $\begin{array}{l}\hat{\tilde{V}} \\
\infty \\
0 \\
0\end{array}$ & $\begin{array}{l}\text { 竎 } \\
\text { o } \\
0\end{array}$ & 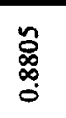 \\
\hline
\end{tabular}


Table 8. Parameters Evolution in the Process of Fuel Irradiation. Reference Uranium Assemblage. No BPR

\begin{tabular}{|c|c|c|c|c|c|c|c|c|c|c|c|c|c|c|c|c|c|c|c|c|c|}
\hline $\begin{array}{c}\text { Irradiation } \\
\text { Point } \rightarrow\end{array}$ & \multicolumn{21}{|c|}{$\begin{array}{c}\text { Burnup, } \\
\text { GWd/t }\end{array}$} \\
\hline $\begin{array}{c}\text { Parameters } \\
\downarrow\end{array}$ & $\theta$ & N & + & 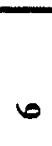 & $\infty$ & 요 & $\simeq$ & \pm & $\mathscr{\ddots}$ & $\underset{\sim}{\infty}$ & శ్ & צ & $\mathbb{A}$ & గั & 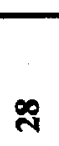 & ק్ & సె & $\vec{m}$ & ஜొ & $\ddot{p}$ & \& \\
\hline Keff & ֶָ๊ & 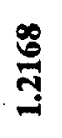 & 홀 & $\frac{0}{9}$ & 穿 & $\stackrel{\infty}{\stackrel{\infty}{m}}$ & $\underset{\Xi}{\stackrel{Z}{Z}}$ & $\stackrel{\infty}{=}$ & 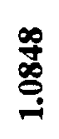 & $\stackrel{\text { : }}{:}$ & 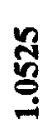 & $\stackrel{\sqrt[3]{5}}{\stackrel{9}{9}}$ & 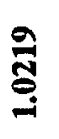 & 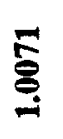 & ్ㅗㅇ & $\frac{\infty}{5}$ & 莣 & $\frac{2}{2}$ & 串 & ֻूँু & $\frac{\stackrel{7}{a}}{3}$ \\
\hline $\mathbf{K o}$ & 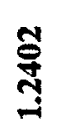 & $\underset{\text { సี }}{\mathfrak{\pi}}$ & ঙ্ & 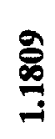 & $\stackrel{\infty}{\stackrel{0}{0}}$ & $\stackrel{n}{\frac{\pi}{7}}$ & 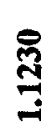 & है & $\stackrel{0}{\infty}$ & $\stackrel{2}{5}$ & 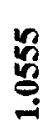 & 离 & 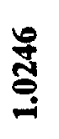 & 홍 & हू & $\begin{array}{l}\stackrel{g}{े} \\
\stackrel{\circ}{0}\end{array}$ & $\begin{array}{l}\hat{:} \\
\text { ڤ̆ }\end{array}$ & 苞 & है & ָั & $\frac{\mathscr{y}}{\hat{\sigma}}$ \\
\hline Kkmax-CS & 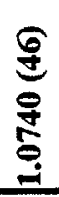 & 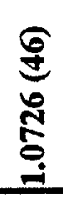 & 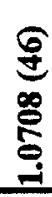 & $\begin{array}{l}\stackrel{6}{9} \\
0 \\
0 \\
0\end{array}$ & 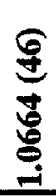 & 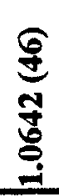 & $\begin{array}{l}6 \\
0 \\
0 \\
0 \\
\end{array}$ & 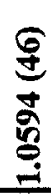 & 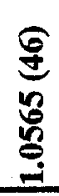 & 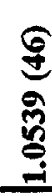 & $\underset{\stackrel{g}{8}}{\stackrel{g}{8}}$ & 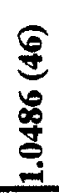 & 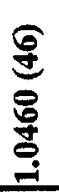 & $\begin{array}{l}\frac{G}{9} \\
\frac{3}{9} \\
\stackrel{9}{9}\end{array}$ & 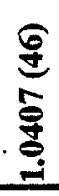 & 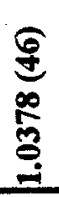 & 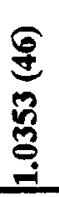 & 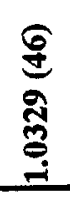 & 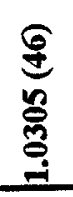 & 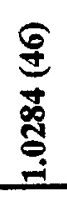 & 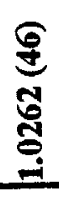 \\
\hline$\beta e f f$ & $\frac{5}{8}$ & 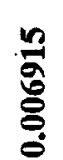 & 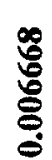 & 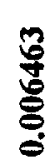 & 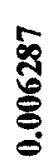 & 衷 & 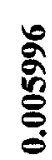 & 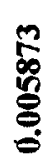 & 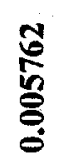 & $\begin{array}{l}8 \\
80 \\
0 \\
0 \\
0\end{array}$ & 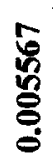 & 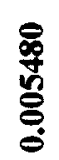 & 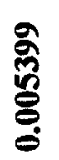 & 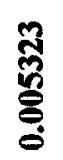 & $\begin{array}{l}\text { ర్ } \\
\text { ర్ } \\
\text { ర్ }\end{array}$ & 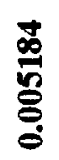 & 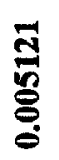 & $\begin{array}{l}\overline{6} \\
\bar{్} \\
\overline{0} \\
0\end{array}$ & 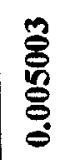 & 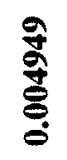 & $\begin{array}{l}5 \\
8 \\
0 \\
8 \\
0\end{array}$ \\
\hline
\end{tabular}




\begin{tabular}{|c|c|c|c|c|c|}
\hline \multirow{21}{*}{$\frac{\tilde{E}}{2} \frac{2}{3}$} & ot & $11166^{\circ}$ & $\angle S 26^{\circ} 0$ & $(9 t)+\varepsilon z 0^{\circ} \mathrm{I}$ & $568+00^{\circ} 0$ \\
\hline & $8 \mathfrak{E}$ & $\nabla \varepsilon 26^{\circ} 0$ & 8LE6 0 & $(9 t) 8920 . \tau$ & $9 t 6700^{\circ} 0$ \\
\hline & $9 \varepsilon$ & $09 \varepsilon 6^{\circ} 0$ & $2056^{\circ} 0$ & $(9 t) \operatorname{Esz0} 0^{\circ}$ & $000500^{\circ} 0$ \\
\hline & $t \varepsilon$ & $06 \pm 6^{\circ} 0$ & $8296^{\circ} 0$ & $(9 t)$ OIE0 $I$ & $9 S 0 S 00^{\circ} 0$ \\
\hline & $z \varepsilon$ & $2296^{\circ} 0$ & $t S \angle 6^{\circ} 0$ & $(9 t) 6 \varepsilon \varepsilon 0^{\circ} \tau$ & SIISO0*0 \\
\hline & $0 \mathcal{E}$ & $9 S \angle 6^{\circ} 0$ & I886 0 & (9t) $I \angle E 0^{\circ} I$ & $\angle L I S 00^{\circ} 0$ \\
\hline & 82 & $\varepsilon 686^{\circ} 0$ & $\angle 000^{\circ} \mathrm{I}$ & $(9 t)$ SOt0 I & $\mathcal{\varepsilon}+z S 00^{\circ} 0$ \\
\hline & 92 & IE00'I & oetoI & (9t) $\mathrm{ztt0^{ \circ } \mathrm { L }}$ & $\bullet$ IES00 0 \\
\hline & $t z$ & ILIO'I & $8 t 20^{\circ} \mathrm{I}$ & (96) $\varepsilon 8+0^{\circ} \mathrm{I}$ & $88 E S 00^{\circ} 0$ \\
\hline & $z z$ & ZIEO'I & 6SE0 $0^{\circ}$ & $(96) Z \mathrm{SO}^{\circ} \mathrm{L}$ & $89+\$ 00^{\circ} 0$ \\
\hline & $0 z$ & $t$ Sto I & $29 t 0^{\circ} \mathrm{I}$ & $(9 t) 6 \angle S 0^{\circ} \mathrm{I}$ & $\downarrow \mathrm{SSSO0} 0$ \\
\hline & $8 \mathrm{I}$ & $\angle 6 S 0^{\circ} \mathrm{I}$ & SSSO I & (9t) $\mathcal{S E 9 0}^{*} \mathrm{~L}$ & $\angle \$ 9500^{\circ} 0$ \\
\hline & 9I & $\tau \leftarrow \angle 0^{\circ} \mathrm{I}$ & LE90'I & (9t) $\angle 690^{\circ} \mathrm{I}$ & $8 t \angle S 00^{\circ} 0$ \\
\hline & $t I$ & $0680^{\circ} \mathrm{I}$ & ZILOII & (9t) $\varepsilon 9 L 0^{\circ} \mathrm{I}$ & $6 S 8 S 00^{\circ} 0$ \\
\hline & ZI & toIII & $08 \angle 0^{\circ} I$ & $(9 t)+\varepsilon 80^{\circ} t$ & $286900^{\circ} 0$ \\
\hline & OI & 66II'I & $\$ t 80^{\circ} I$ & (9t) $\angle 060^{\circ} \mathrm{I}$ & $811900^{\circ} 0$ \\
\hline & 8 & t9EI'I & $\angle 060^{\circ} \mathrm{I}$ & (9t) $\varepsilon 860^{\circ} \mathrm{I}$ & ELZ900 0 \\
\hline & 9 & 9ESI'I & $0 \angle 60^{\circ} \mathrm{I}$ & $(9 t) 6 \mathrm{SOI}^{\circ} \mathrm{I}$ & ISt900\% \\
\hline & 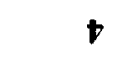 & ZLLI'I & $620 I^{\circ} \mathrm{I}$ & (9t) $9 \varepsilon \mathrm{EII} I$ & $099900^{\circ} 0$ \\
\hline & $z$ & $\operatorname{cs8I}^{\circ} \mathrm{I}$ & 9LOI'I & 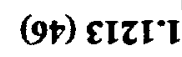 & IL6900 \\
\hline & $\mathbf{0}$ & $\operatorname{Ltoz} I$ & EIII'I & $(9 t) 68 Z I \cdot I$ & $66 \mathrm{I} \angle 00^{\circ} 0$ \\
\hline 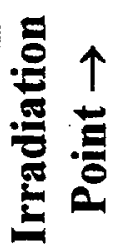 & 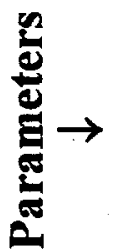 & 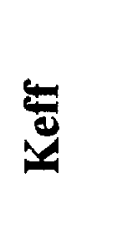 & \& & 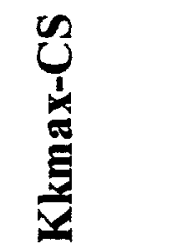 & $\stackrel{2}{2}$ \\
\hline
\end{tabular}


Table 10. Parameters Evolution in the Process of Fuel Irradiation. MOX LTA 4.4/3.0/2.4

\begin{tabular}{|c|c|c|c|c|c|c|c|c|c|c|c|c|c|c|c|c|}
\hline $\begin{array}{c}\text { Irradiation } \\
\text { Point } \rightarrow\end{array}$ & \multicolumn{16}{|c|}{$\begin{array}{c}\text { Burnup, } \\
\text { GWd/t }\end{array}$} \\
\hline $\begin{array}{c}\text { Parameters } \\
\downarrow\end{array}$ & 0 & 4 & + & 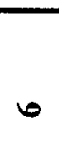 & $\infty$ & 요 & $\mathcal{Z}$ & \pm & 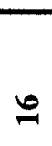 & $\stackrel{\infty}{=}$ & శ్ & $\mathcal{N}$ & $a$ & हె & लू & F \\
\hline Keff & $\stackrel{2}{n}$ & 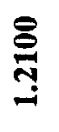 & $\stackrel{\infty}{\beth}$ & $\stackrel{0}{\tilde{\sigma}}$ & $\stackrel{5}{3}$ & $\underset{3}{3}$ & $\stackrel{m}{=}$ & 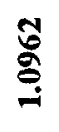 & $\stackrel{\circ}{\stackrel{2}{\circ}}$ & 导 & 乐 & 禺 & $\underline{0}$ & âे & 竎 & ్ֶఞ \\
\hline Ko & 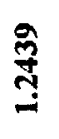 & $\stackrel{9}{9}$ & $\stackrel{2}{2}$ & $\stackrel{2}{2}$ & 气ิ & $\stackrel{\infty}{=}$ & $\stackrel{3}{=}$ & $\stackrel{5}{5}$ & $\stackrel{\infty}{\infty}_{-\infty}^{\infty}$ & : & $\stackrel{\infty}{\frac{\pi}{g}}$ & 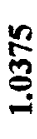 & है & 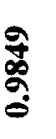 & בัּ & $\frac{1}{2}$ \\
\hline Kkmax-CS & $\stackrel{\infty}{\stackrel{\infty}{\infty}}$ & 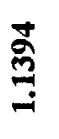 & $\stackrel{9}{0}$ & 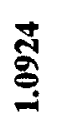 & $\stackrel{\infty}{\stackrel{\infty}{\infty}}$ & $\stackrel{\overline{2}}{\stackrel{0}{\varrho}}$ & $\stackrel{\infty}{5}$ & $\stackrel{5}{9}$ & $\stackrel{\bar{s}}{\stackrel{5}{\circ}}$ & $\stackrel{8}{\circ}$ & ت্ & 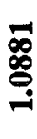 & $\bar{g}$ & 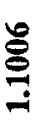 & స્સે & $\exists$ \\
\hline
\end{tabular}


Table 11. Parameters Evolution in the Process of Fuel Irradiation. MOX LTA 4.4/3.0/2.0

\begin{tabular}{|c|c|c|c|c|c|c|c|c|c|c|c|}
\hline $\begin{array}{l}\text { Irradiation } \\
\text { Point } \rightarrow\end{array}$ & \multicolumn{10}{|c|}{$\begin{array}{l}\text { Burnup, } \\
\text { GWd/t }\end{array}$} & \\
\hline $\begin{array}{c}\text { Parameters } \\
\downarrow\end{array}$ & 0 & N & + & 6 & $\infty$ & & 2 & & $\stackrel{\infty}{=}$ & N & 9 \\
\hline Keff & ঙั & సิ & 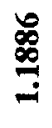 & 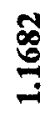 & $\stackrel{5}{ \pm}$ & 률 & $\bar{z}$ & & 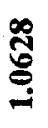 & ్ֻ & 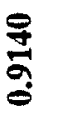 \\
\hline Ko & 范 & ฐ̆ & $\underset{0}{2}$ & $\stackrel{8}{\stackrel{8}{5}}$ & $\stackrel{J}{J}$ & 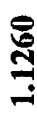 & $\stackrel{\alpha}{g}$ & & $\underset{\square}{\vec{\Delta}}$ & ڤ్ట̆ & సू̆ \\
\hline Kkmax-CS & 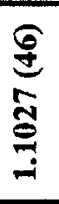 & 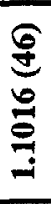 & 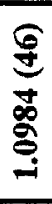 & $\begin{array}{l}\frac{\theta}{9} \\
\bar{g} \\
\end{array}$ & 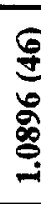 & $\begin{array}{l}8 \\
\\
\stackrel{9}{9} \\
\end{array}$ & s & & 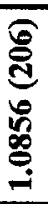 & 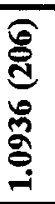 & 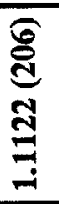 \\
\hline$\beta$ eff & 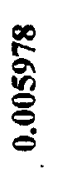 & 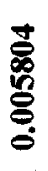 & 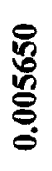 & 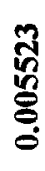 & $\frac{8}{8}$ & $\stackrel{\overbrace{}}{0}$ & 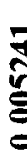 & & 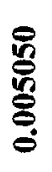 & $\frac{\bar{\aleph}}{\stackrel{\check{\delta}}{8}}$ & 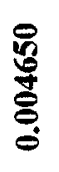 \\
\hline
\end{tabular}




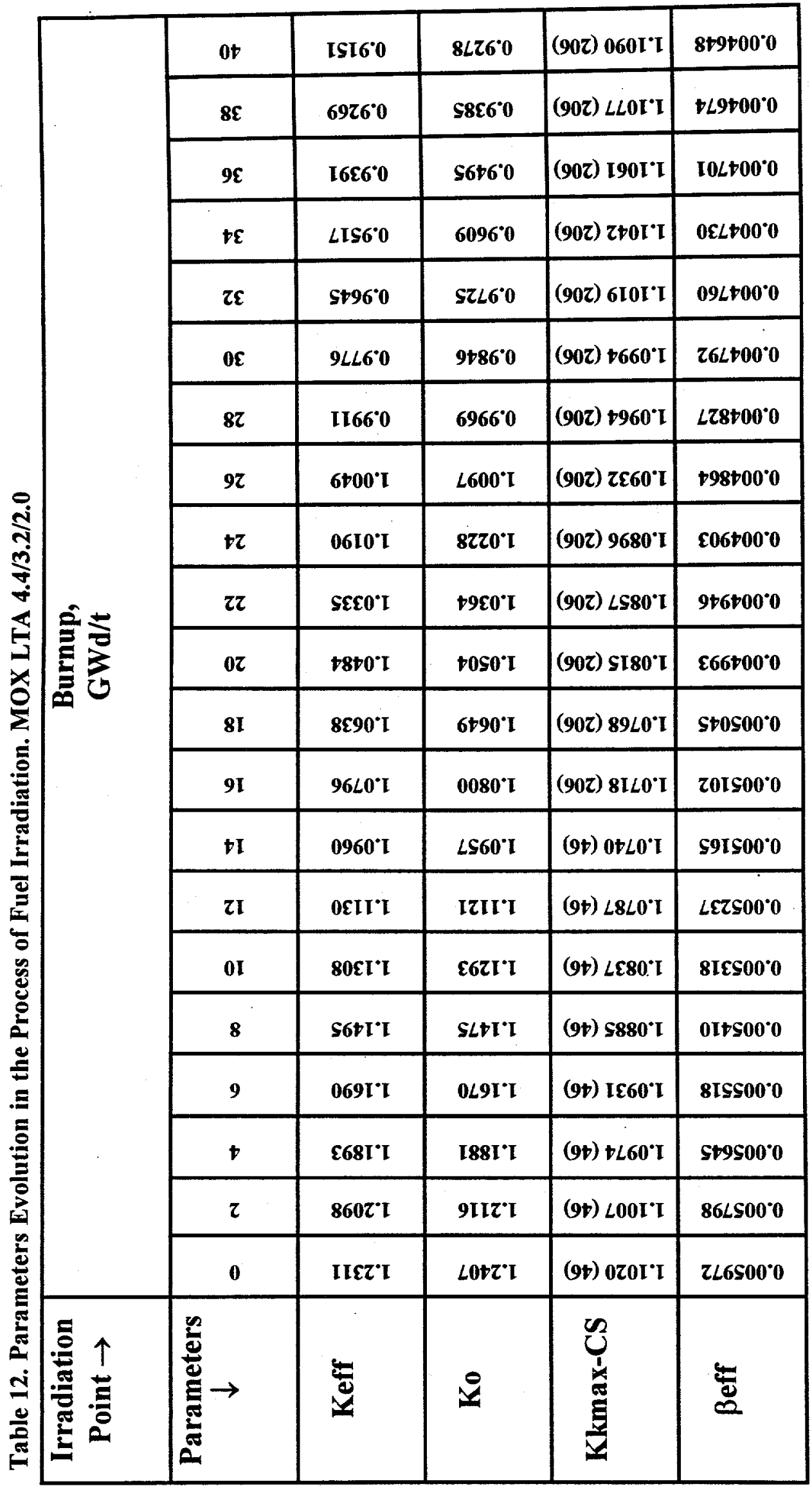




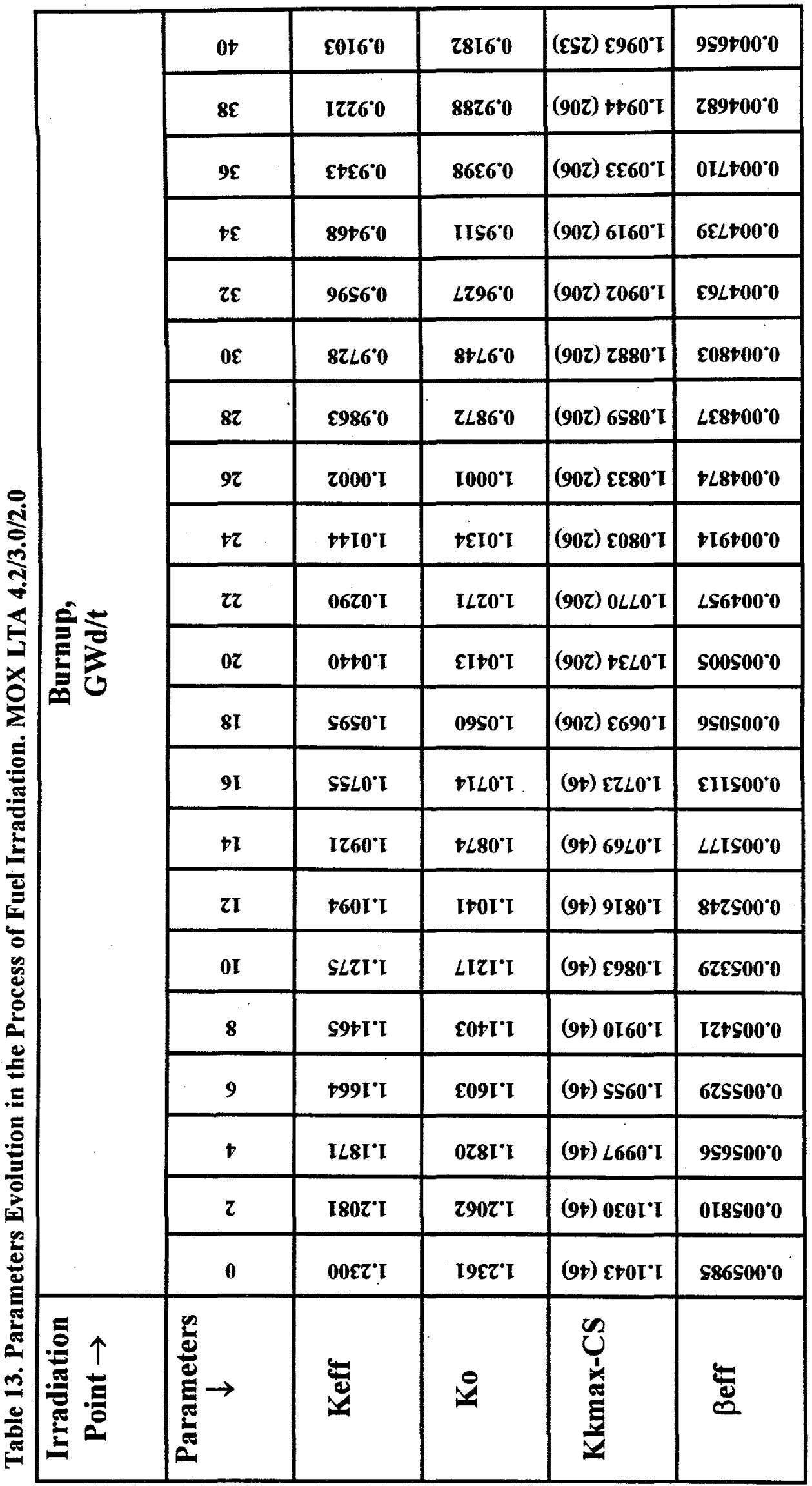


Table 14. Parameters Evolution in the Process of Fuel Irradiation. MOX LTA 3.8/2.8/U-3.7

\begin{tabular}{|c|c|c|c|c|c|c|c|c|c|c|c|c|c|c|c|c|c|c|c|c|c|}
\hline $\begin{array}{c}\text { Irradiation } \\
\text { Point } \rightarrow\end{array}$ & \multicolumn{21}{|c|}{$\begin{array}{c}\text { Burnup, } \\
\text { GWd/t }\end{array}$} \\
\hline $\begin{array}{c}\text { Parameters } \\
\downarrow\end{array}$ & 0 & $N$ & $\checkmark$ & 0 & $\infty$ & 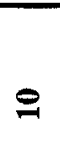 & $\simeq$ & \pm & 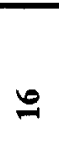 & $\stackrel{\infty}{=}$ & สิ & ส & $\vec{A}$ & $\stackrel{1}{\pi}$ & $\infty$ & p & ल & मे & i & $\stackrel{\infty}{\infty}$ & P \\
\hline Keff & 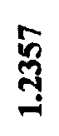 & 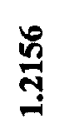 & 隹 & 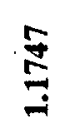 & : & 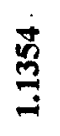 & $\stackrel{9}{\Xi}$ & 莺 & 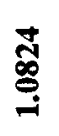 & : & : & 窎 & $\stackrel{5}{9}$ & 商 & 产 & 总 & 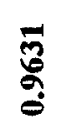 & $\begin{array}{l}\infty \\
\stackrel{0}{+} \\
\stackrel{8}{0}\end{array}$ & 兽 & ฐ̊ & a \\
\hline Ko & 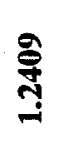 & త్ & $\stackrel{\square}{3}$ & $\stackrel{\mathscr{D}}{\leftrightarrows}$ & 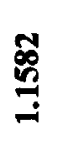 & 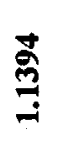 & $\underset{ت}{ت}$ & 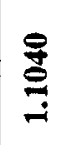 & : & 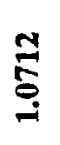 & 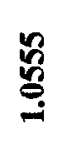 & 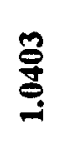 & : & $\Xi$ & òे & 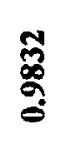 & 형 & 蒙 & 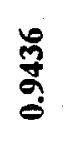 & 롱 & $\frac{a}{a}$ \\
\hline Kkmax-CS & 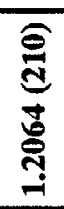 & 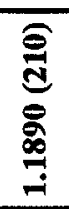 & 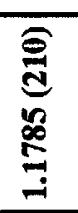 & $\begin{array}{l}\underset{\mathrm{g}}{\mathrm{d}} \\
\underset{\mathrm{Z}}{\mathrm{G}}\end{array}$ & 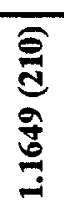 & 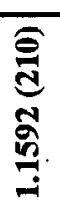 & 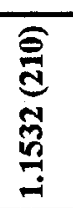 & 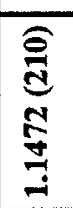 & 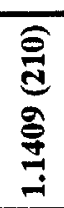 & 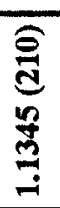 & 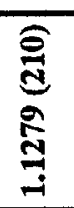 & 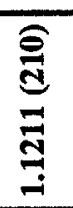 & 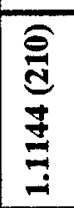 & $\begin{array}{l}\text { 氖 } \\
\text { : } \\
\text { : }\end{array}$ & 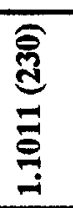 & 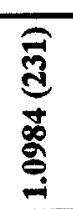 & 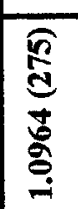 & 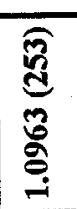 & 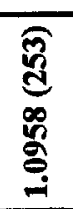 & 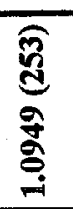 & 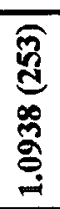 \\
\hline$\beta$ eff & 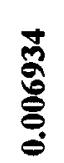 & 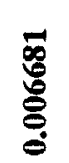 & 总 & 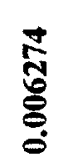 & م. & 怘 & 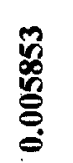 & 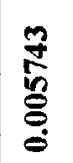 & 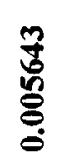 & 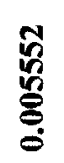 & 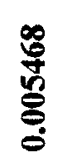 & 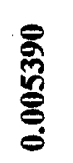 & 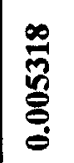 & 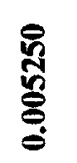 & 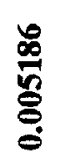 & 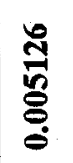 & 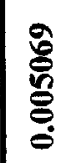 & 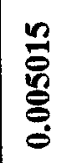 & 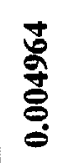 & $\begin{array}{l}\frac{n}{3} \\
\text { बेㅎㅇ } \\
\stackrel{0}{0}\end{array}$ & 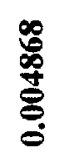 \\
\hline
\end{tabular}


品

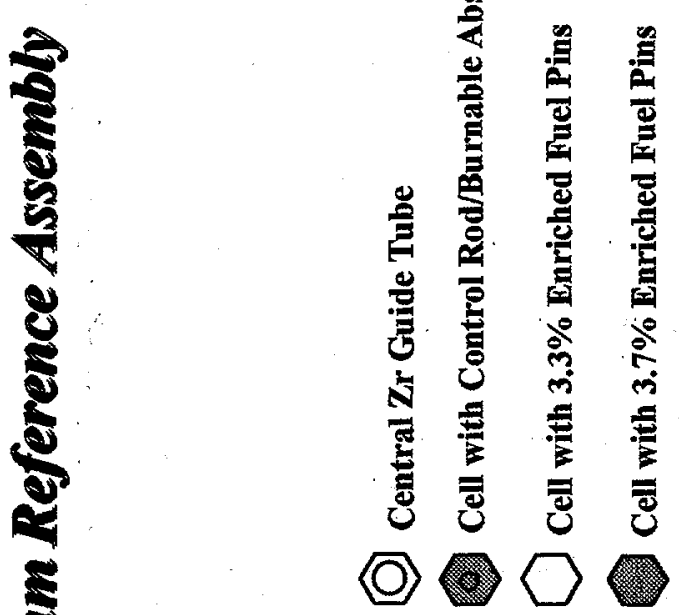

产 
RUSSIAN RESEARCH CENTER KURCHATOV INSTITUTE

Results of Parametric Design Studies of MOX Lead Test Assembly (Final Report for FY98)

Figure 2. Calculational Model for Reference Uranium Assembly Surrounded by Uranium Assemblies. $60^{\circ}$ Sector

\author{
26, \\ 71,25 , \\ $71,71,25$, \\ $71,71,71,25$, \\ $71,71,71,71,25$, \\ $71,71,71,71,71,25$, \\ $29,71,71,71,71,71,25$, \\ $71,71,71,71,71,71,71,25$ \\ $71,71,71,29,71,71,71,71,25$, \\ $\mathbf{7 1}, 29,71,71,71,71,71,71,71,25$, \\ $\mathbf{7 1}, 71,71,71,71,71,71,71,71,71,25$, \\ $27,71,71,71,71,29,71,71,71,71,71,26$, \\ $71,71,71,29,71,71,71,71,71,71,71,25,64$, \\ $71,71,71,71,71,71,71,71,71,71,71,25,64,64$, \\ $71,71,29,71,71,71,29,71,71,71,71,25,64,50,50$, \\ $71,71,71,71,71,71,71,71,71,71,71,25,64,50,50,50$, \\ $29,71,71,71,71,29,71,71,71,71,71,25,64,50,50,50,50$, \\ $71,71,71,29,71,71,71,71,71,71,71,25,64,50,50,50,50,29$, \\ $71,71,71,71,71,71,71,71,71,71,71,25,64,50,50,50,50,50,50$, \\ $71,71,71,71,71,71,71,71,71,71,71,25,64,50,5050,29,50,50,50$, \\ $71,71,71,71,71,71,71,71,71,71,71,25,64,50,50,50,50,50,50,50,50$, \\ $71,71,71,71,71,71,71,71,71,71,71,25,64,50,50,50,50,50,50,29,50,50$, \\ $26,25,25,25,25,25,25,25,25,25,25,26,64,64,50,50,50,29,50,50,50,50,27$, \\ 25 - side water cell \\ 26 - corner water cell \\ 27 - central tube cell \\ 29 - guide tube cell / burnable absorbers \\ 50 - uranium $3.7 \%$ U-235 fuel rods \\ 64 - uranium $3.3 \%$ U-235 fuel rods \\ 71 - uranium $3.7 \%$ U-235 fuel rods
}




\section{Figure 3. Simplified Design for 3 Zones MOX LTA}

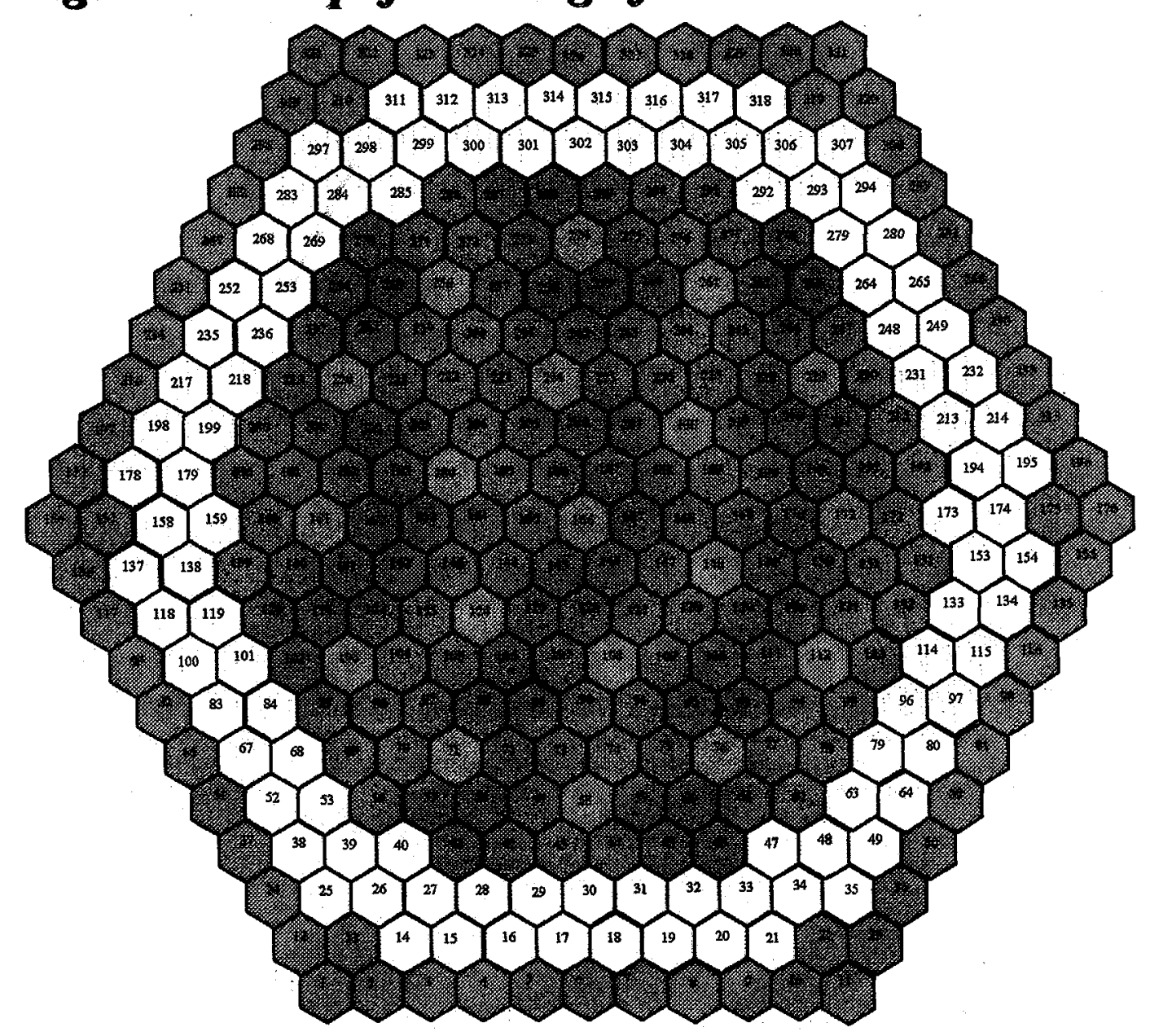

1 Low Plutonium-Content MOX Rods

Intermediate Plutonium-Content MOX Rods
High Plutonium-Content MOX Rods

0 Central tube

2 Control Rods / Burnable Absorbers 
RUSSIAN RESEARCH CENTER KURCHATOV INSTITUTE

Results of Parametric Design Studies of MOX Lead Test Assembly (Final Report for FY98)

Figure 4. Calculational Model for 3-Zones (100\% Plutonium) MOX LTA Surrounded by Uranium Assemblies. $60^{\circ}$ Sector

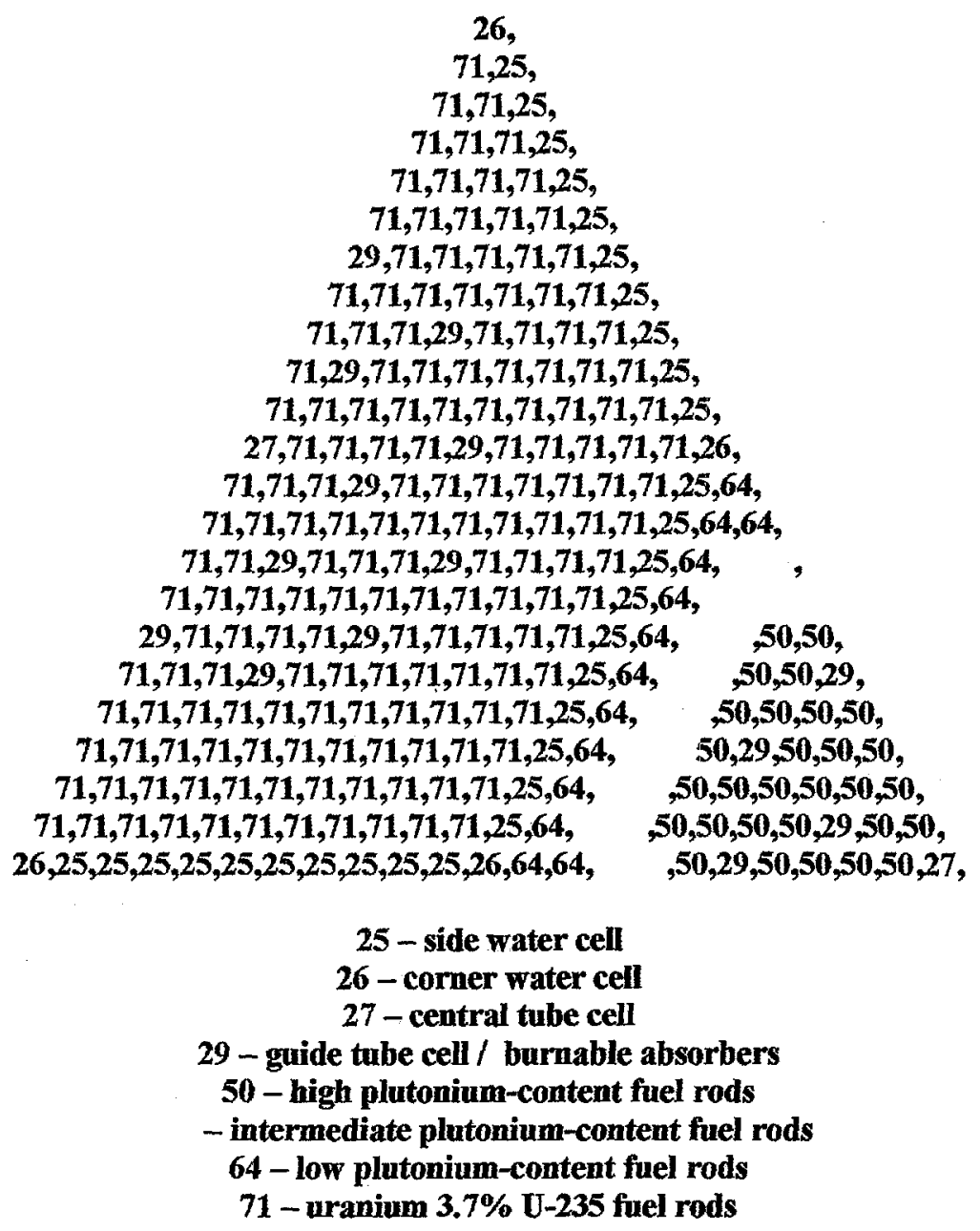




\section{Figure 5. Simplified Design for "Island-1" Type MOX LTA}

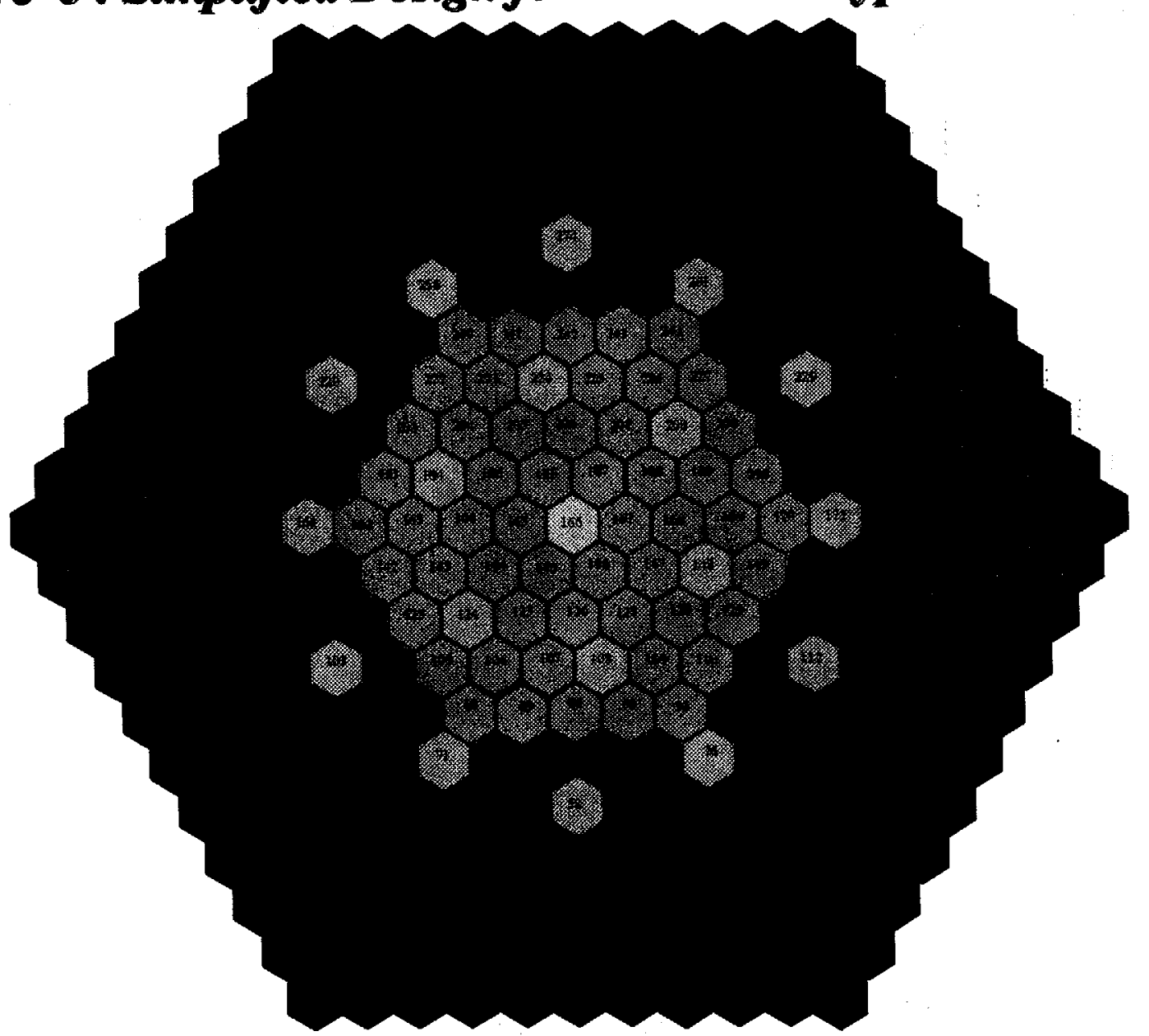

Enriched Uranium Rods

- High Plutonium-Content MOX Rods
(1) Central tube

- Control Rods / Burnable Absorbers 
RUSSIAN RESEARCH CENTER KURCHATOV INSTITUTE

Results of Parametric Design Studies of MOX Lead Test Assembly (Final Report for FY98)

Figure 6. Calculational Model for "Island-1" MOX LTA Surrounded by Uranium Assemblies. $60^{\circ}$ Sector

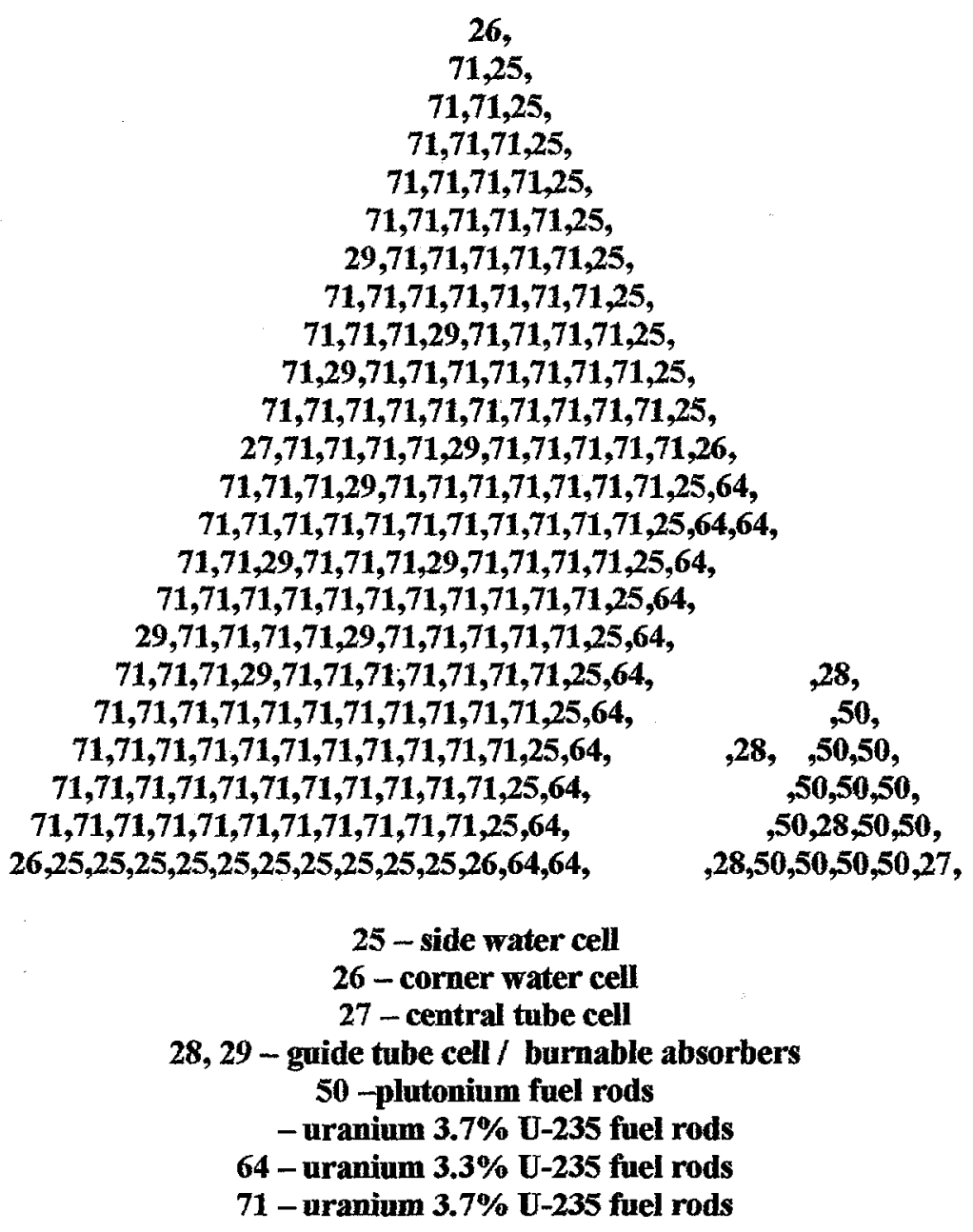




\section{Figure 7. Simplified Design for "Island-2" Type MOX LTA}

Enriched Uranium Rods

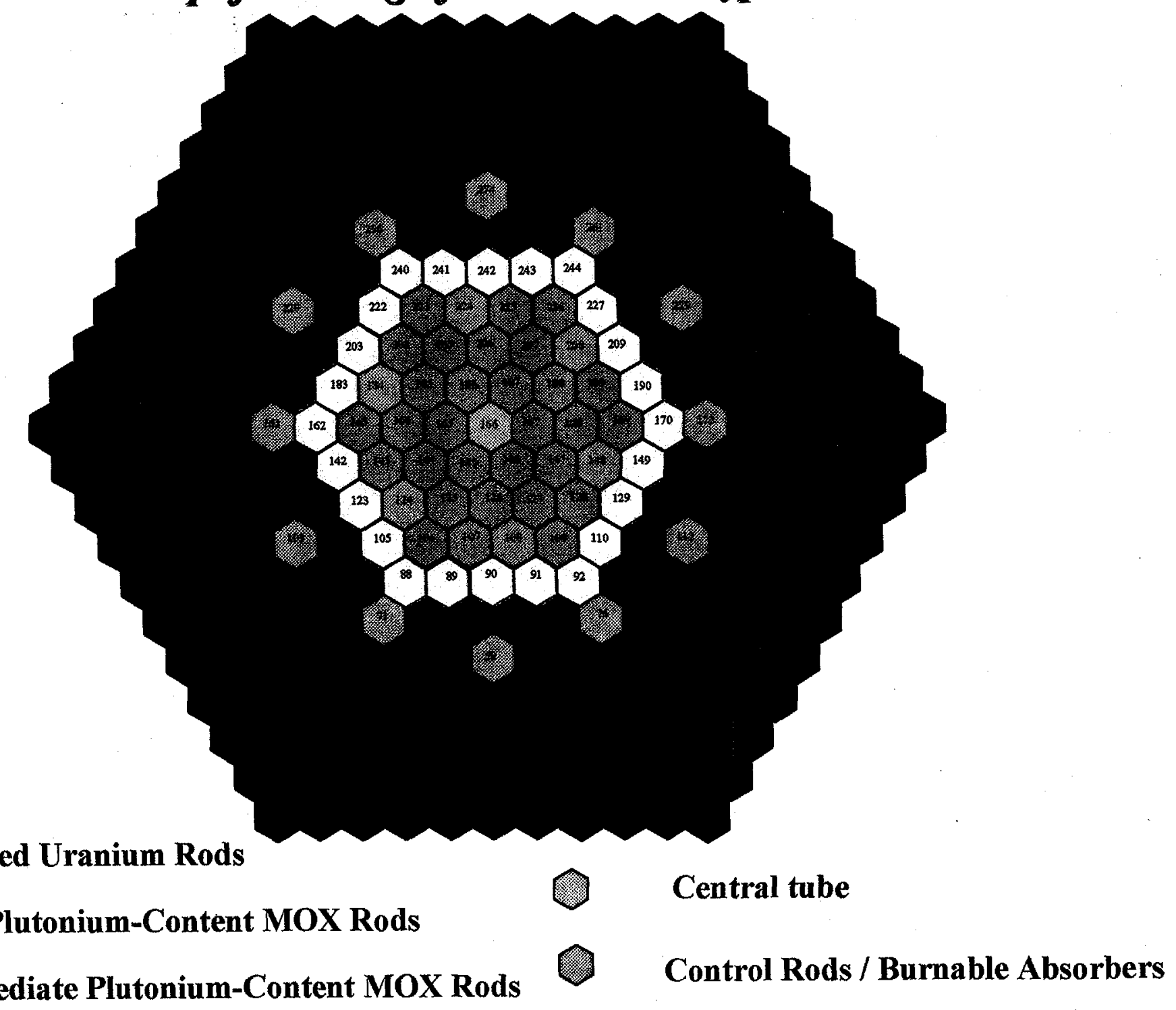

Intermediate Plutonium-Content MOX Rods 
RUSSIAN RESEARCH CENTER KURCHATOV INSTITUTE

Results of Parametric Design Studies of MOX Lead Test Assembly (Final Report for FY98)

Figure 8. Calculational Model for "Island-2" MOX LTA Surrounded by Uranium Assemblies. $60^{\circ}$ Sector

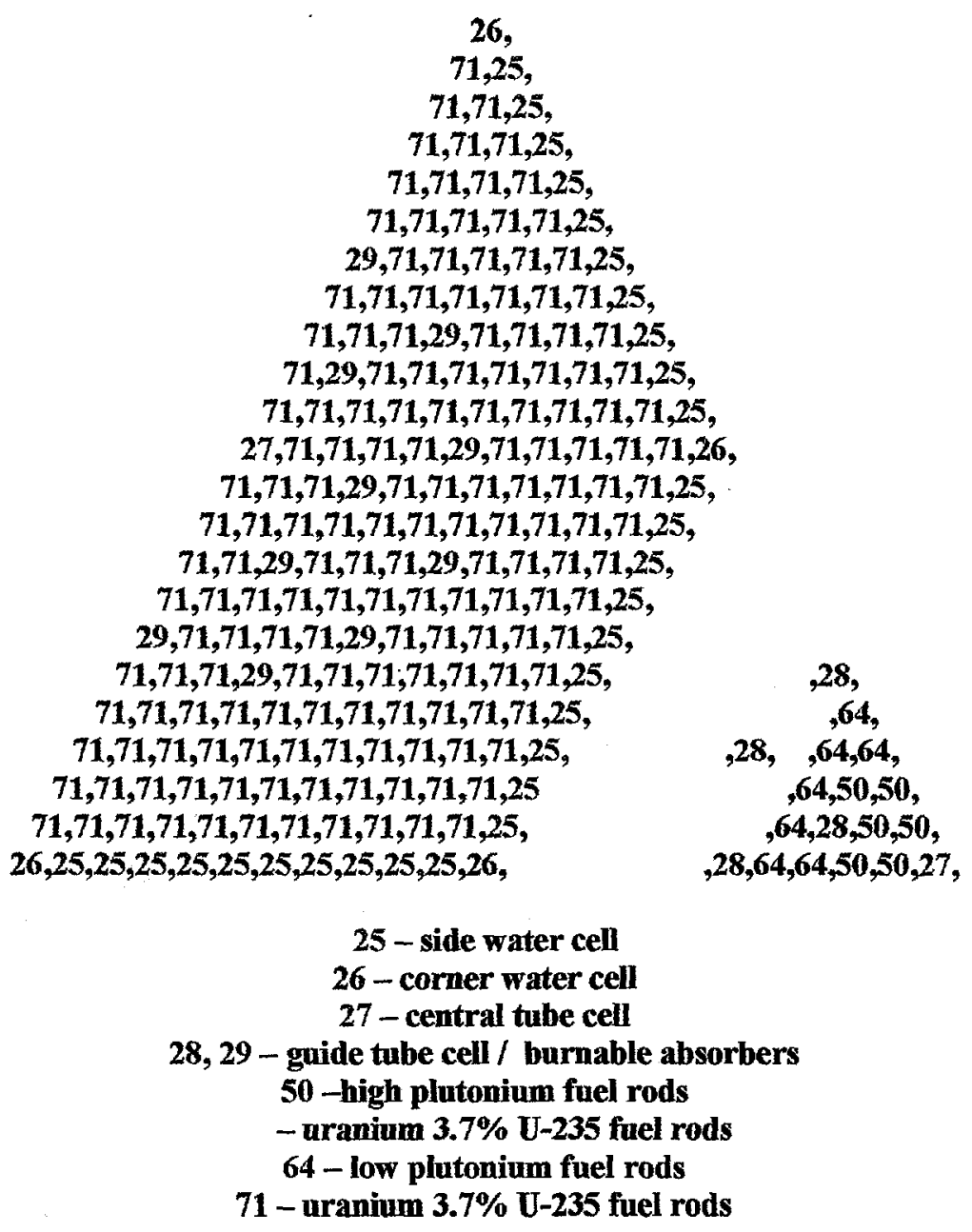


RUSSIAN RESEARCH CENTER KURCHATOV INSTITUTE

Results of Parametric Design Studies of MOX Lead Test Assembly (Final Report for FY98)

Figure 9. Pins Numeration in CS Model

\author{
1 , \\ 2,3 , \\ $4,5,6$, \\ $7,8,9,10$, \\ $11,12,13,14,15$, \\ $16,17,18,19,20,21$, \\ $22,23,24,25,26,27,28$, \\ $29,30,31,32,33,34,35,36$, \\ $37,38,39,40,41,42,43,44,45$, \\ $46,47,48,49,50,51,52,53,54,55$, \\ $56,57,58,59,60,61,62,63,64,65,66$, \\ $67,68,69,70,71,72,73,74,75,76,77,78$, \\ $79,80,81,82,83,84,85,86,87,88,89,90,91$, \\ $92,93,94,95,96,97,98,99,100,101,102,103,104,105$, \\ $106,107,108,109,110,111,112,113,114,115,116,117,118,119,120$, \\ $121,122,123,124,125,126,127,128,129,130,131,132,133,134,135,136$, \\ $137,138,139,140,141,142,143,144,145,146,147,148,149,150,151,152,153$, \\ $154,155,156,157,158,159,160,161,162,163,164,165,166,167,168,169,170,171$, \\ $172,173,174,175,176,177,178,179,180,181,182,183,184,185,186,187,188,189,190$, \\ $191,192,193,194,195,196,197,198,199,200,201,202,203,204,205,206,207,208,209,210$, \\ $211,212,213,214,215,216,217,218,219,220,221,222,223,224,225,226,227,228,229,230,231$,

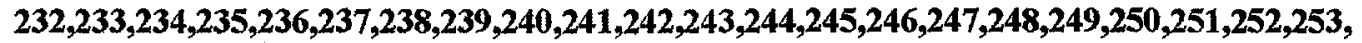 \\ $254,255,256,257,258,259,260,261,262,263,264,265,266,267,268,269,270,271,272,273,274,275,276$, \\ 257 - side water cell \\ 254 - corner water cell \\ 276 - central tube cell \\ 137 - guide tube cell / burnable absorbers \\ 223 -plutonium fuel rods \\ 71 - uranium 3.7\% U-235 fuel rods
}


$\exists$

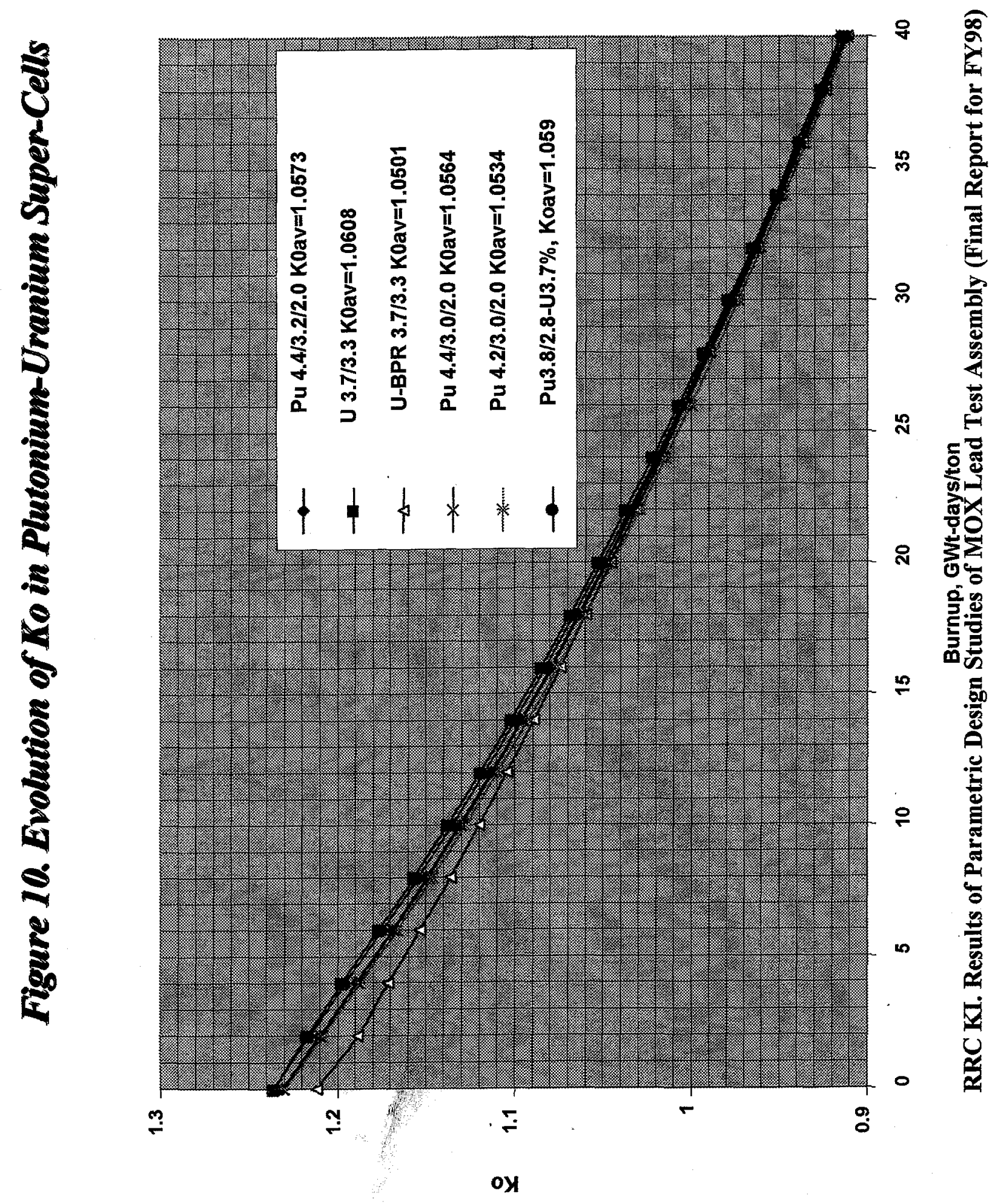




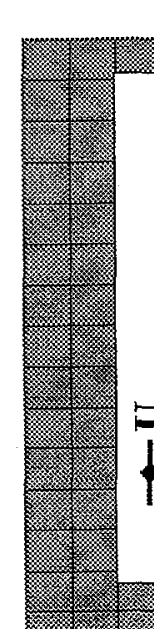

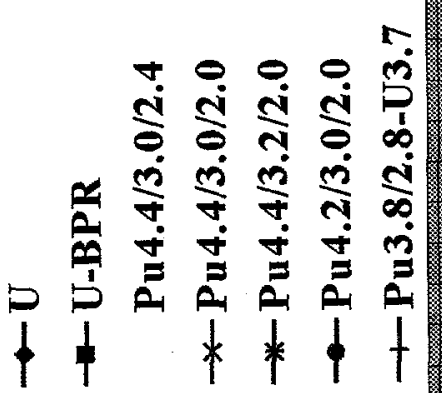

2

F
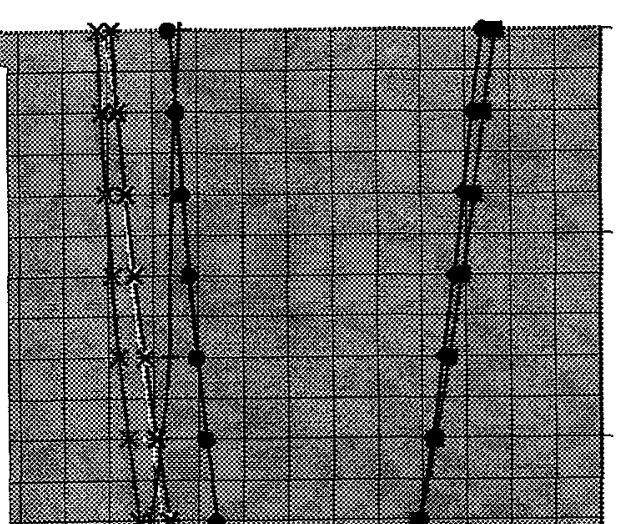

4

훙
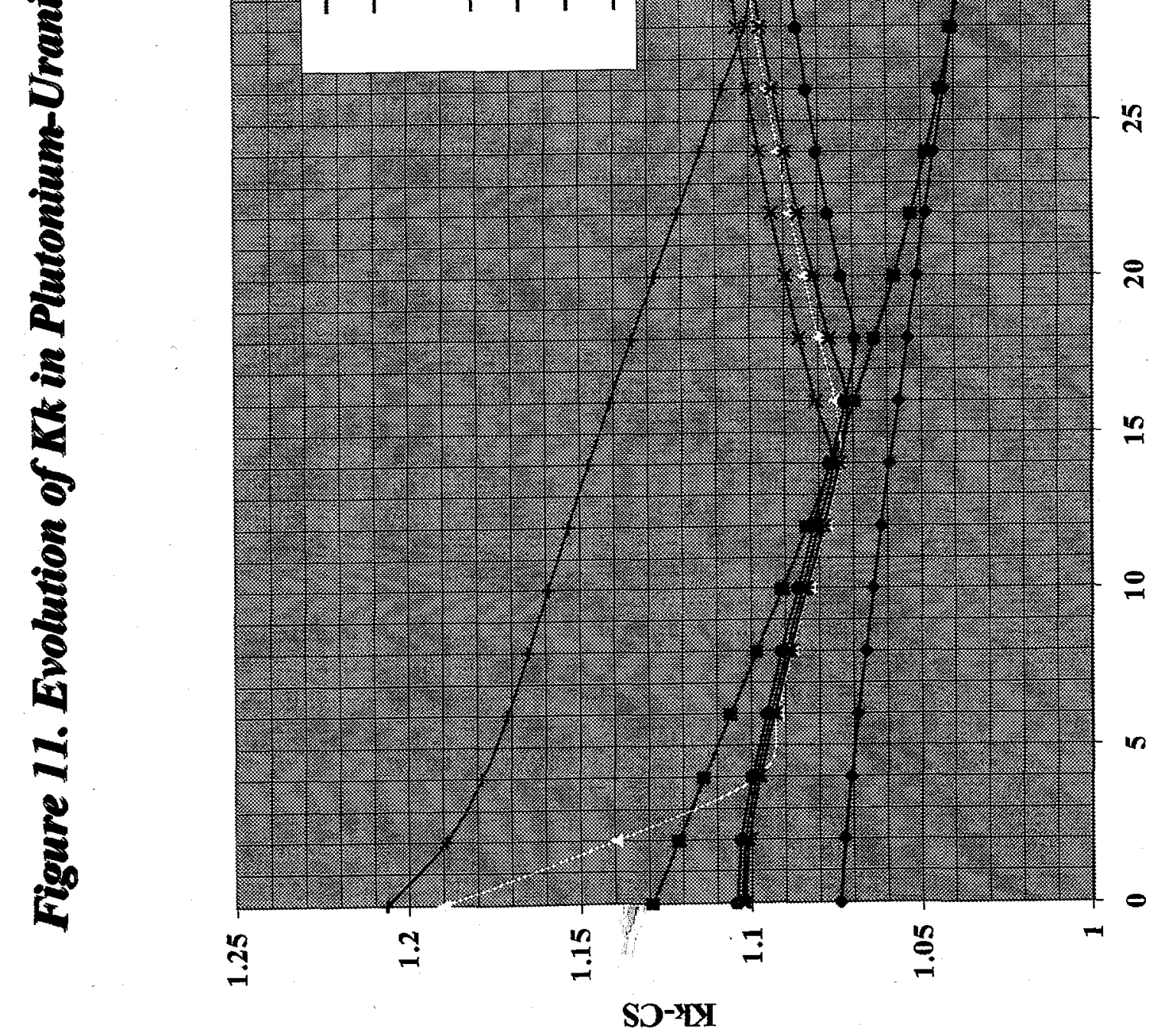

$$
\text { . }
$$




\section{Figure 12. Parametric Studies of "Island" Type MOX LTA (U 3.7\%)}

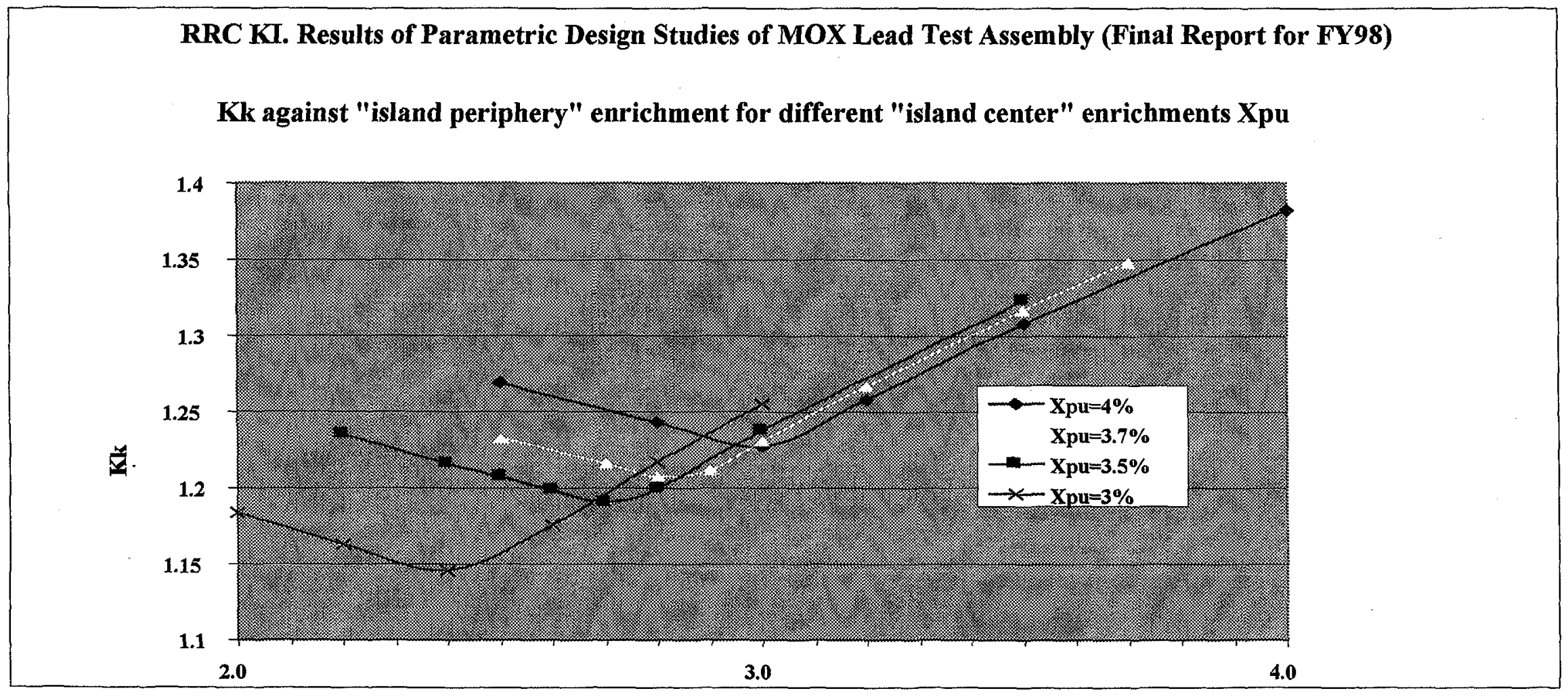

"Island periphery" enrichment of fissile Plutonium, \%
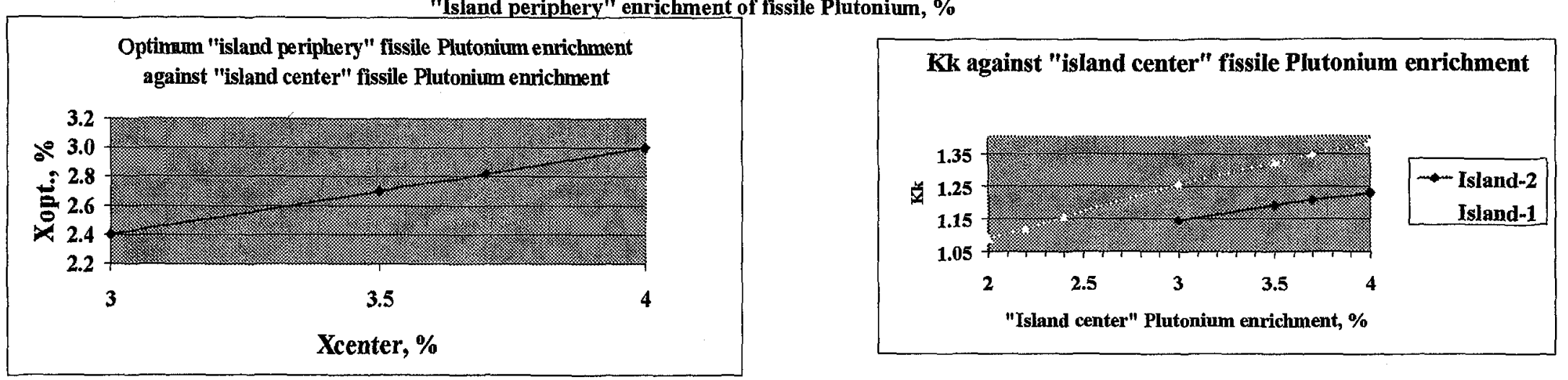


\section{Figure 13. Parametric Studies of "Island" Type MOX LTA (U 4.4\%)}
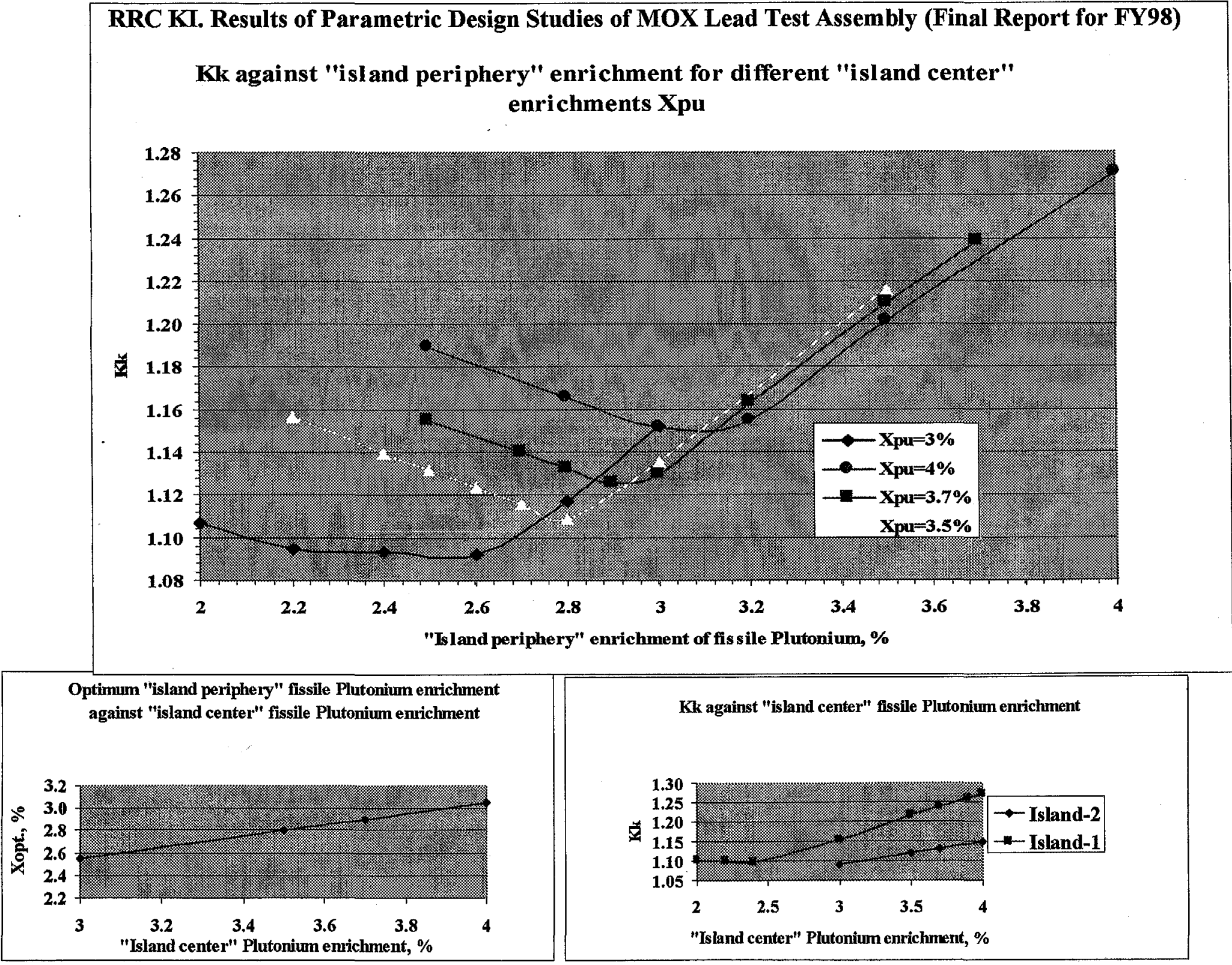
Figure 14. Simplified Design for "Increased Island-2" Type MOX LTA

Enriched Uranium Rods

(-) High Plutonium-Content MOX Rods

Intermediate Plutonium-Content MOX Rods

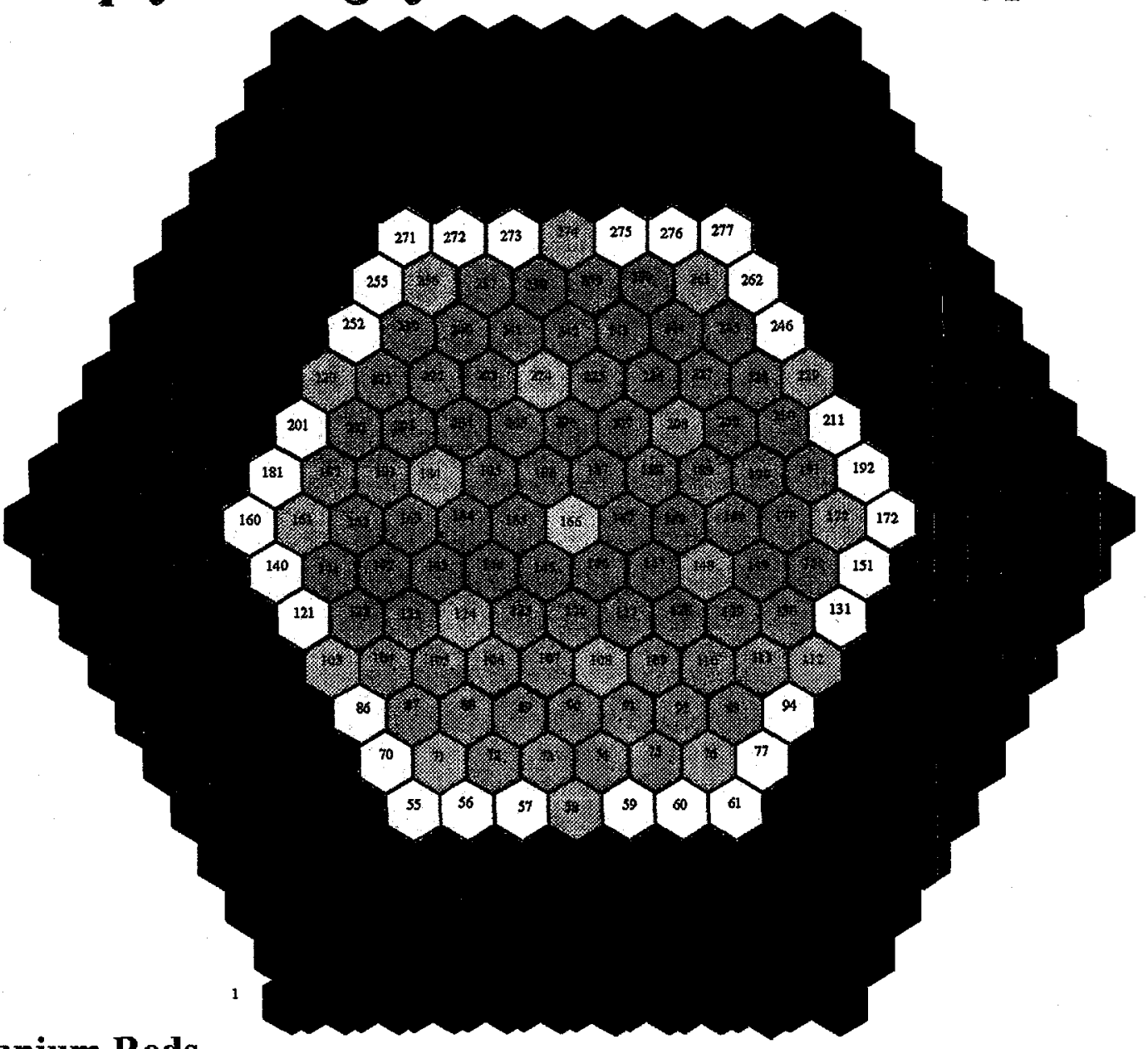

(1) Central tube

Control Rods / Burnable Absorbers 
Fig. 15. Kk against "Island" periphery enrichment for different "Island" size. "Island central enrichment $-\mathbf{4 . 0} \%$.

Uranium enrichment $-3.7 \%$.

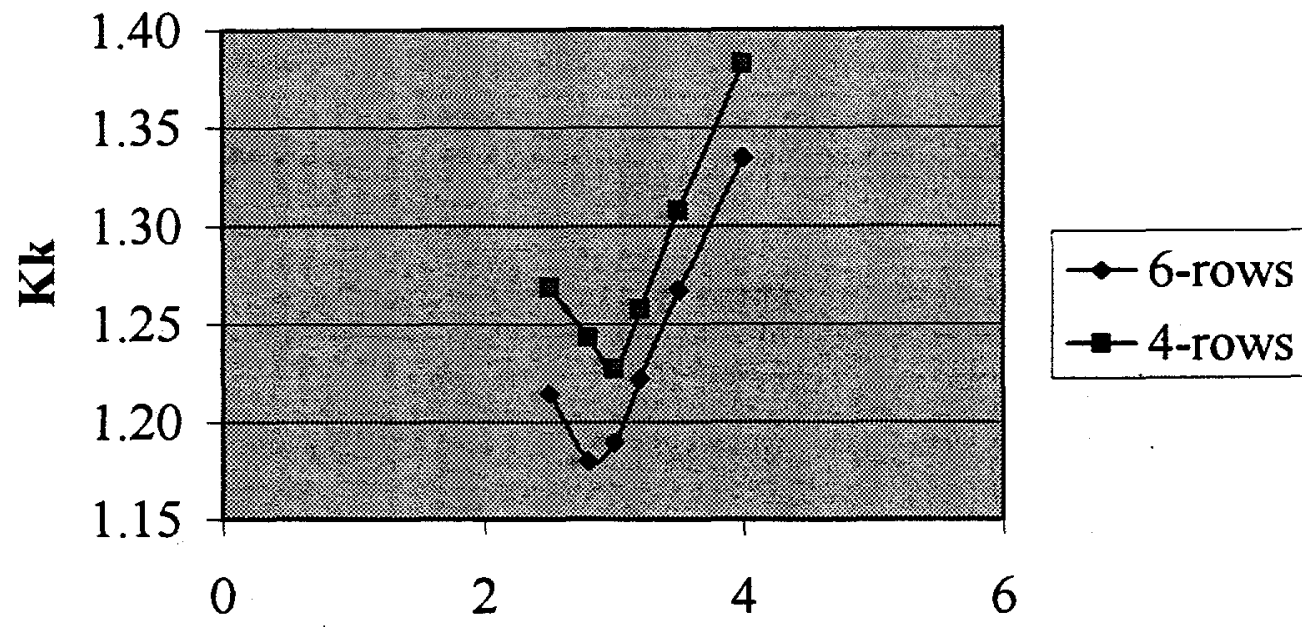

Plutonium enrichment in "Island" periphery

(\%)

Fig. $16 \quad$ Kk against "Island" periphery enrichment for different

"Island" size. "Island central enrichment - 4.0\%. Uranium enrichment $-4.4 \%$.

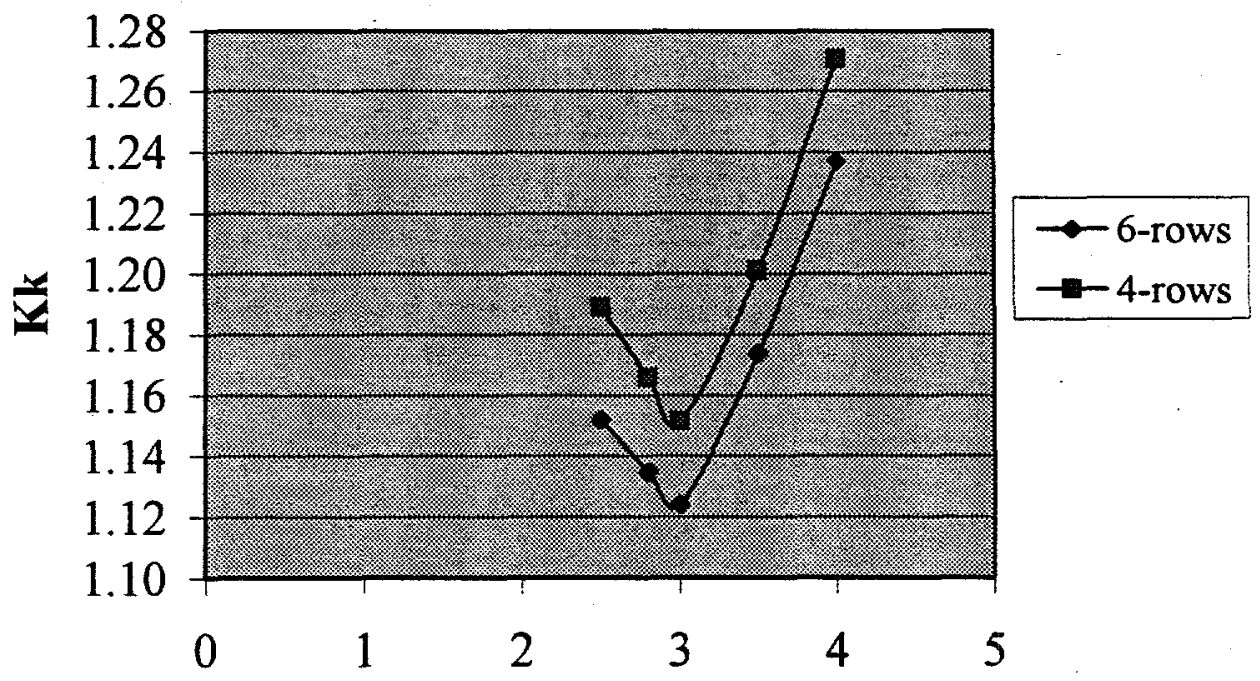

Plutonium enrichment in "Island" periphery (\%) 

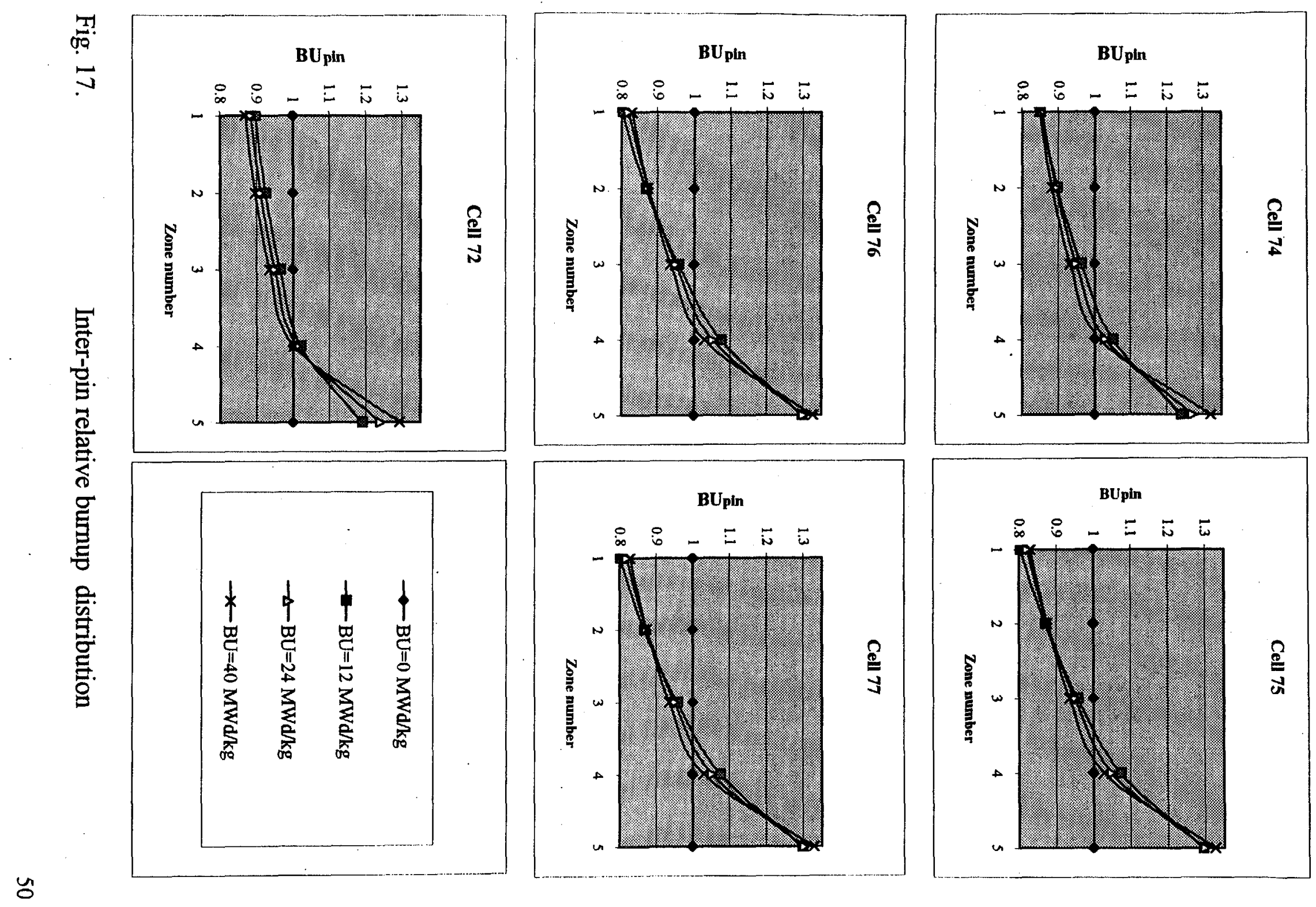

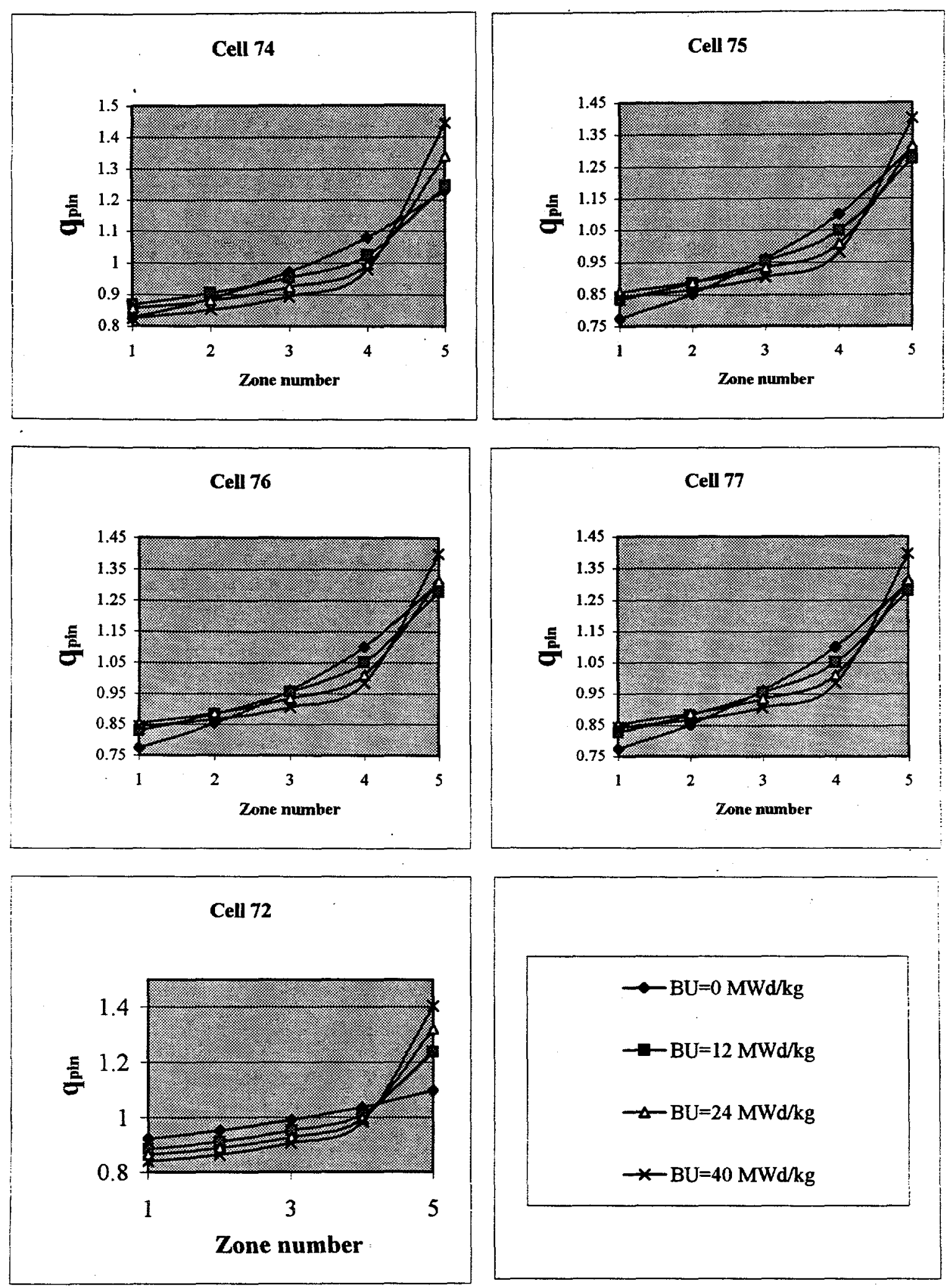

Fig. 18.

Inter-pin relative power distribution 


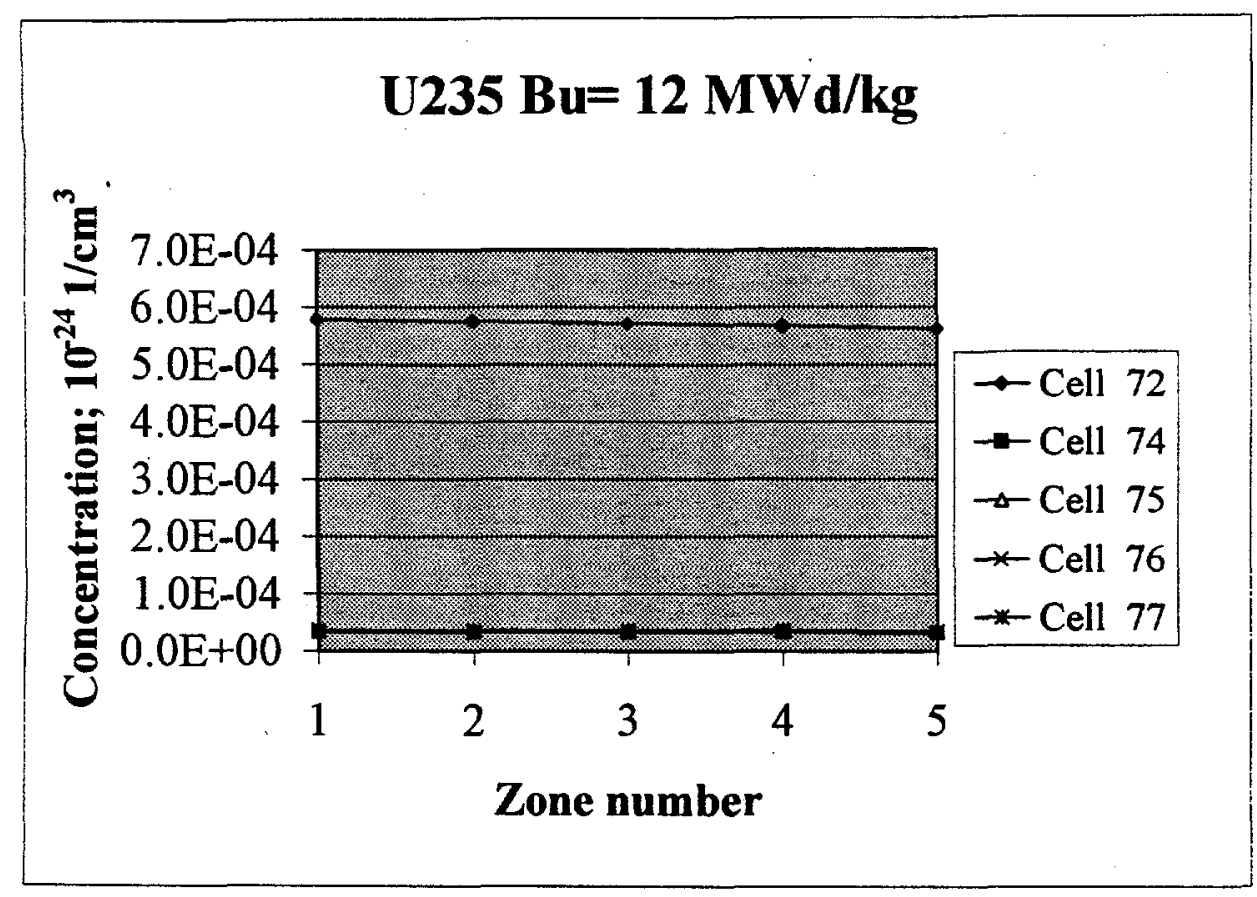

Fig. 19.

Inter-pin isotopic distribution

\section{U235 BU $=40 \mathrm{MWd} / \mathrm{kg}$}

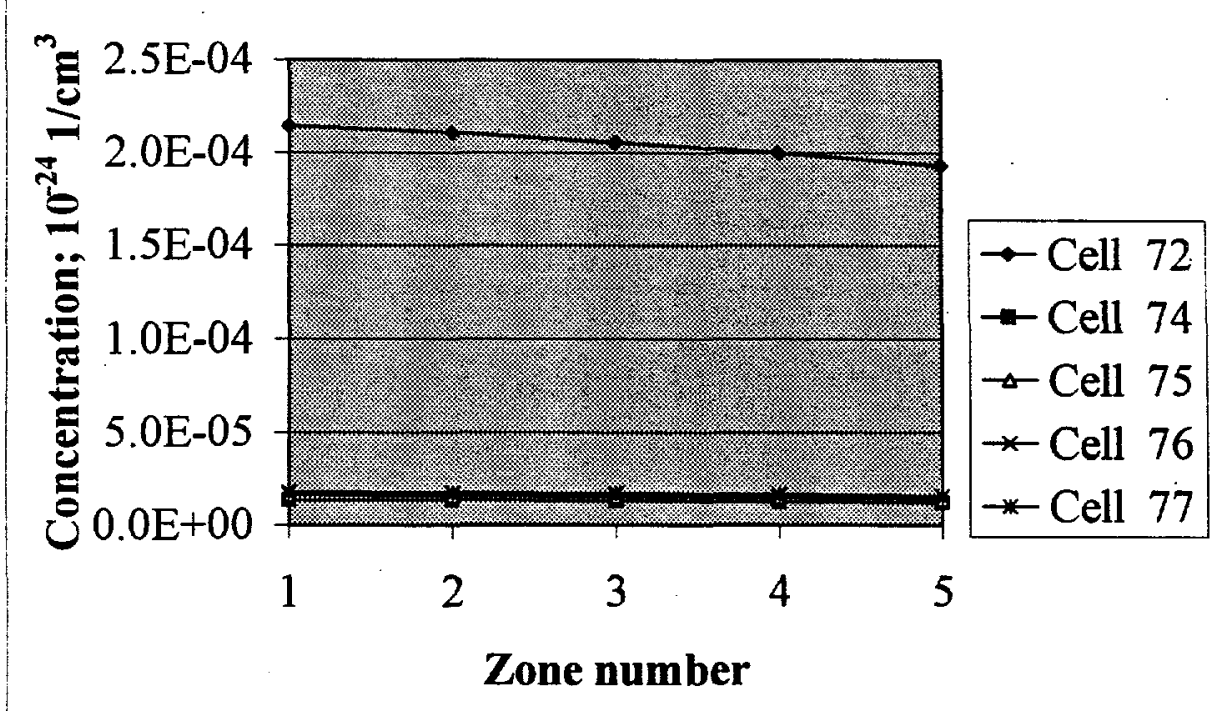

Fig. 20.

Inter-pin isotopic distribution 


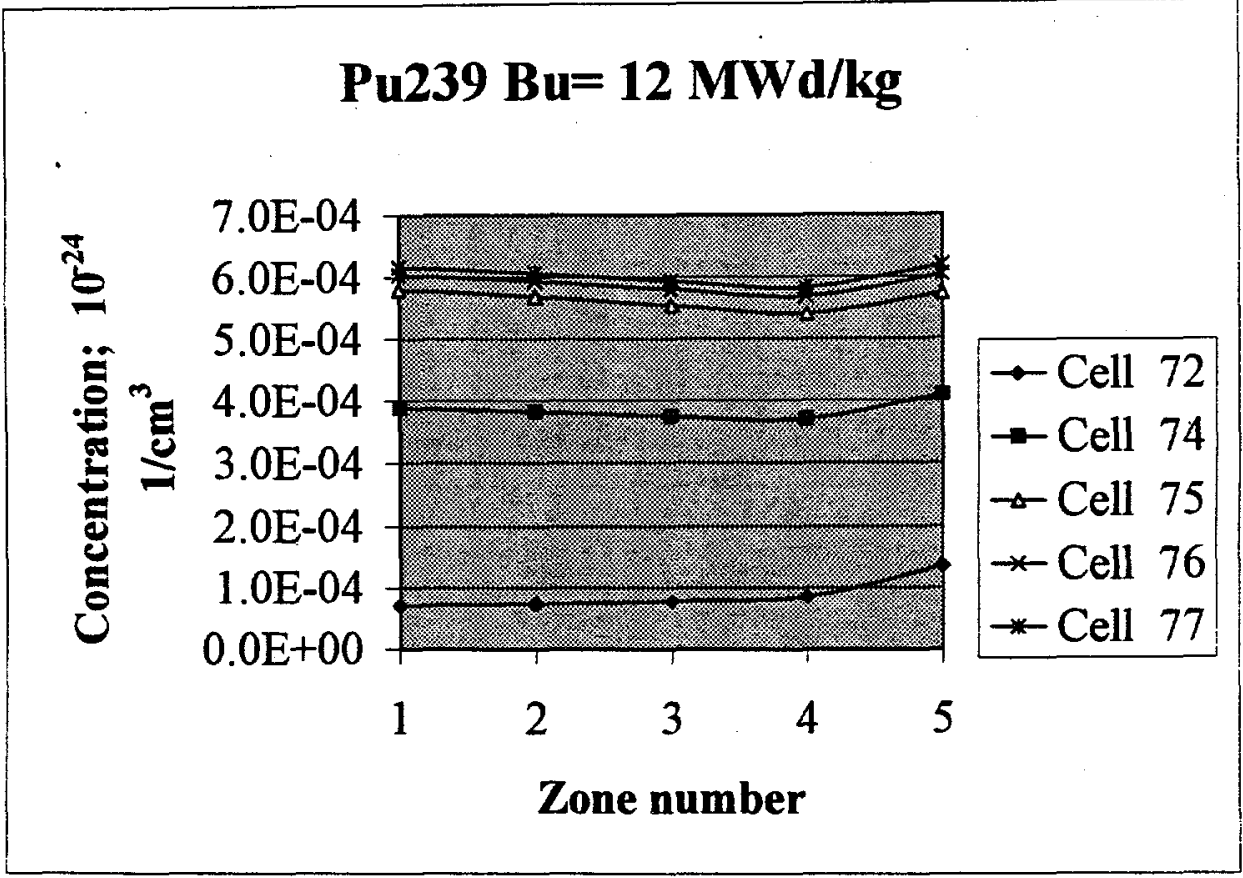

Fig. 21.

Inter-pin isotopic distribution

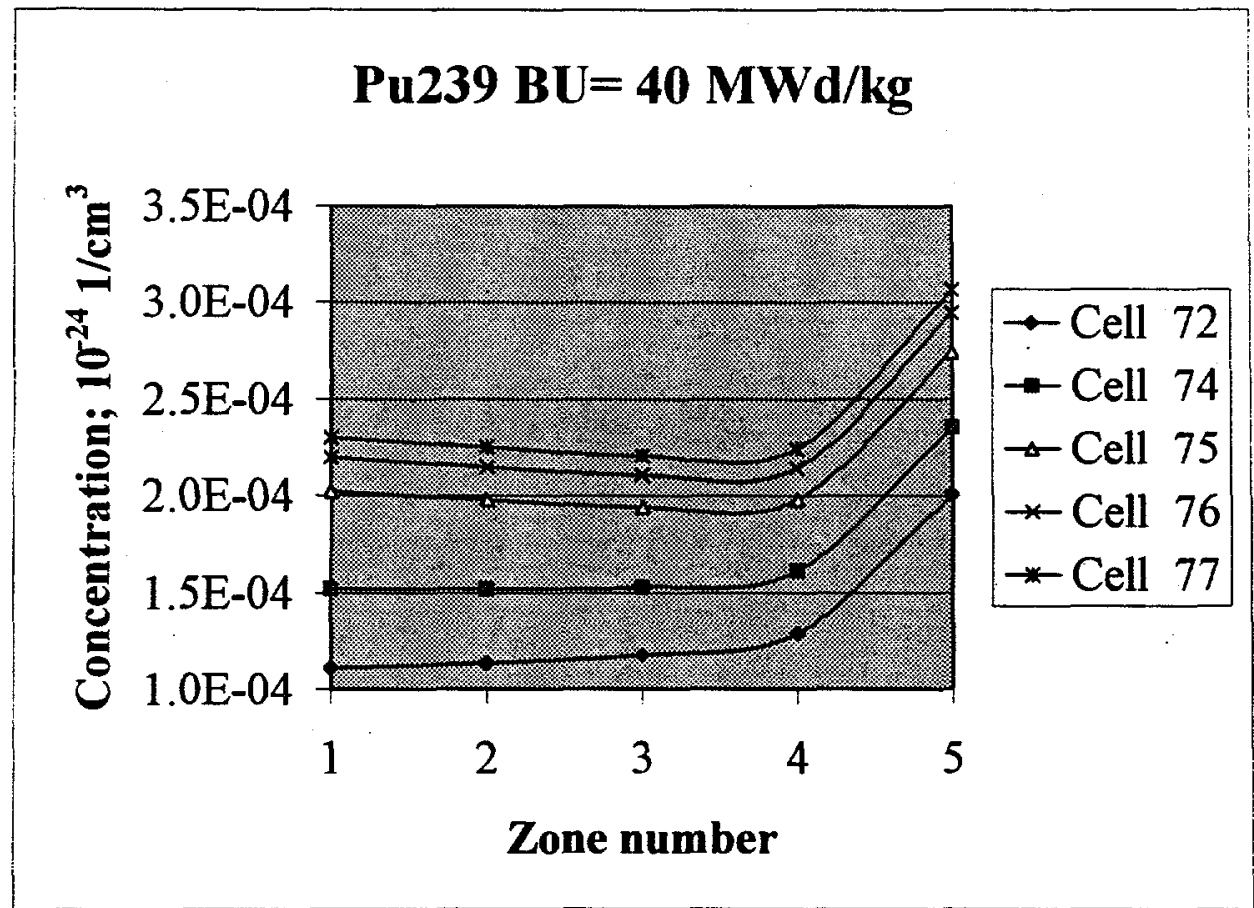

Fig. 22.

Inter-pin isotopic distribution 


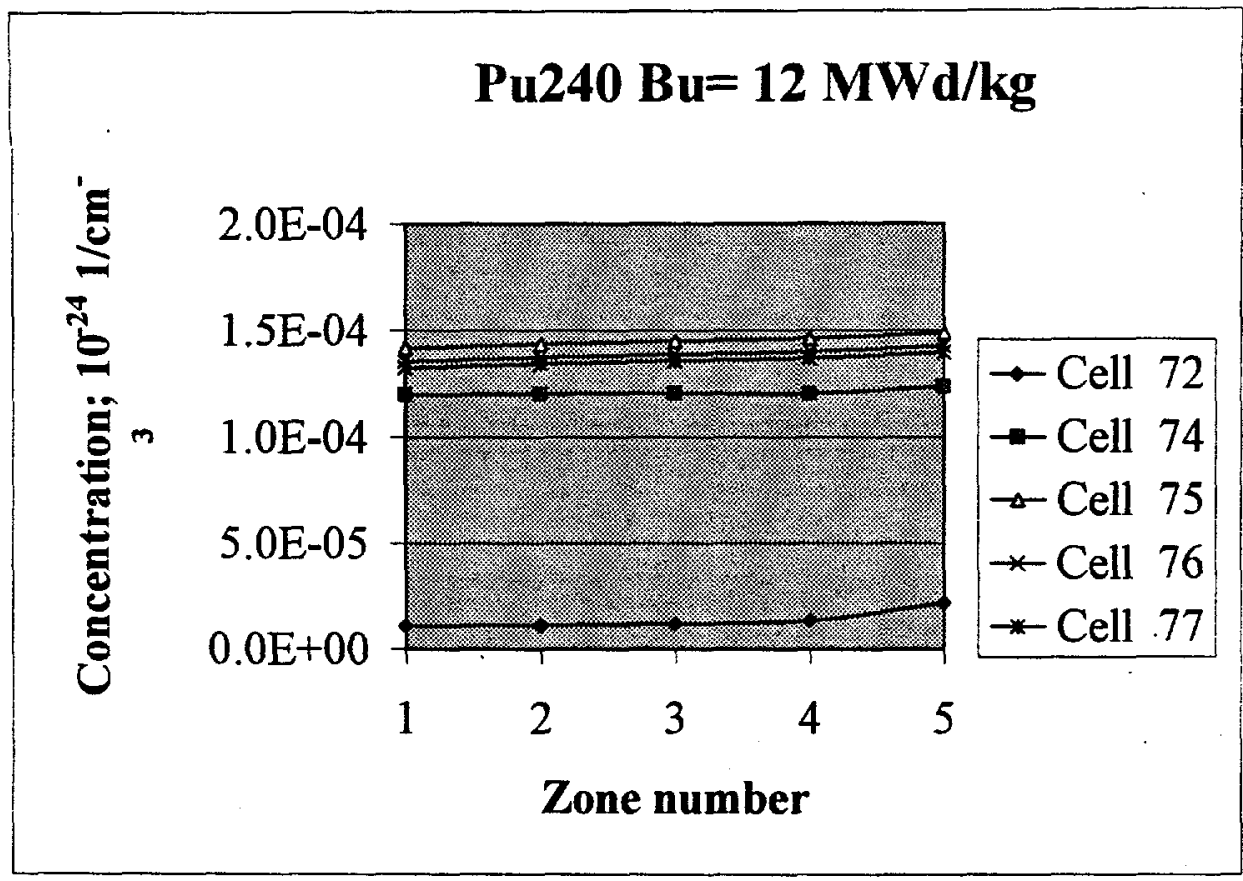

Fig. 23.

Inter-pin isotopic distribution

\section{Pu240 BU= $40 \mathrm{MWd} / \mathrm{kg}$}

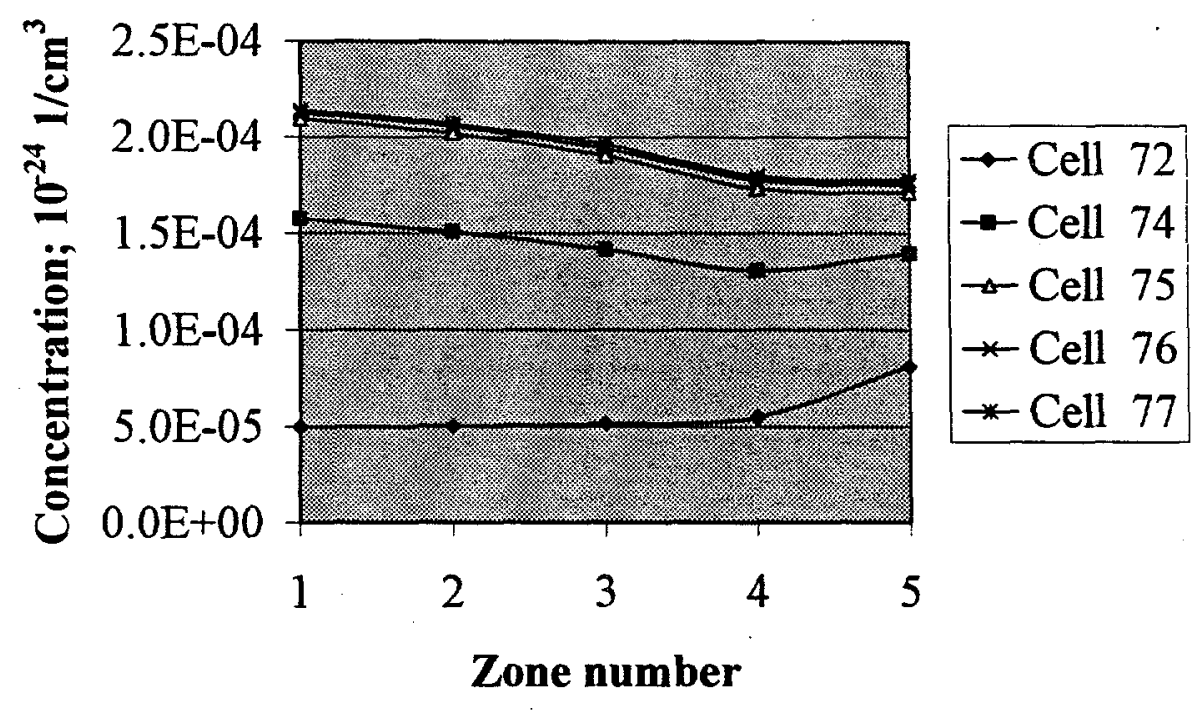

Fig. 24.

Inter-pin isotopic distribution 


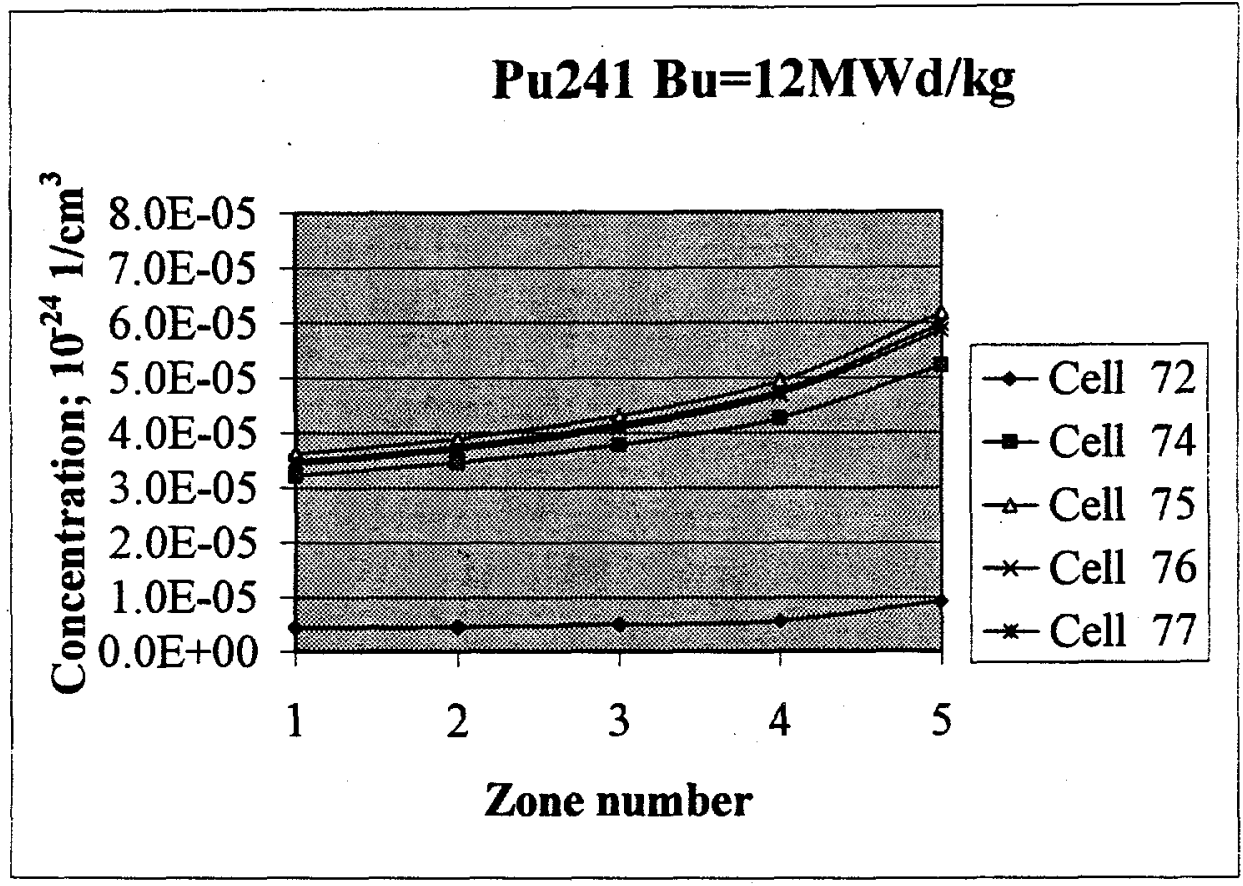

Fig. 25.

Inter-pin isotopic distribution

\section{Pu241 BU= $40 \mathrm{MWd} / \mathrm{kg}$}

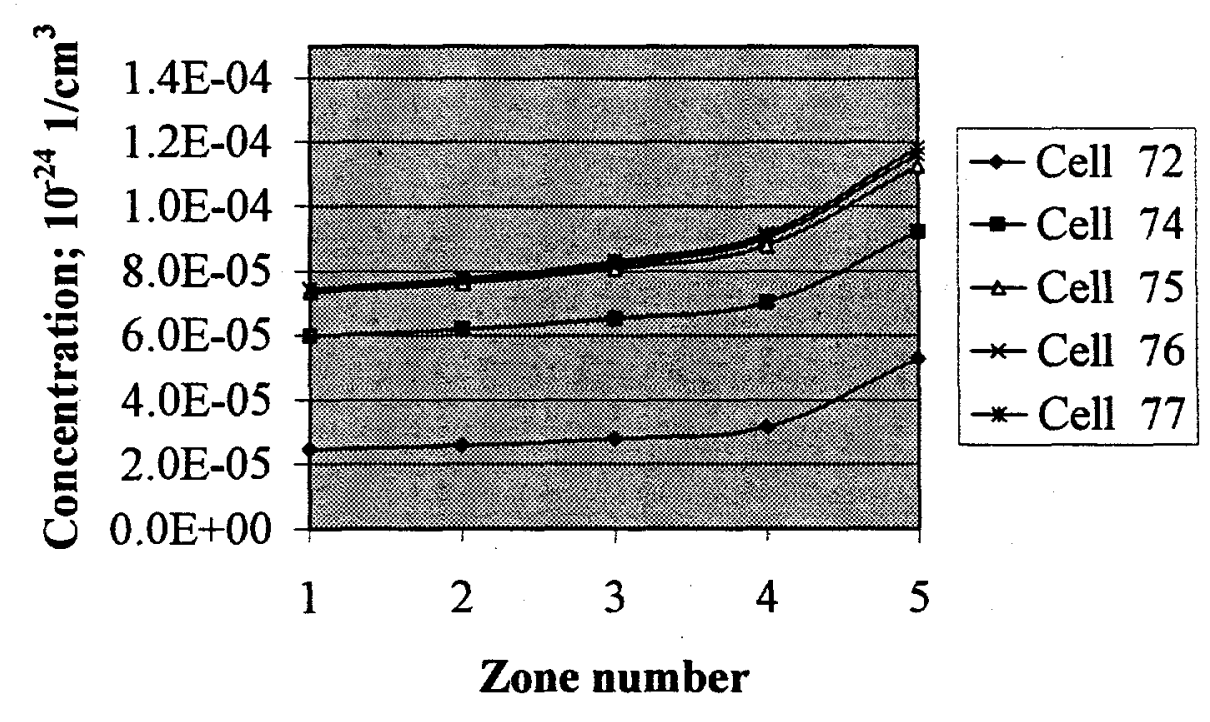

Fig. 26.

Inter-pin isotopic distribution 


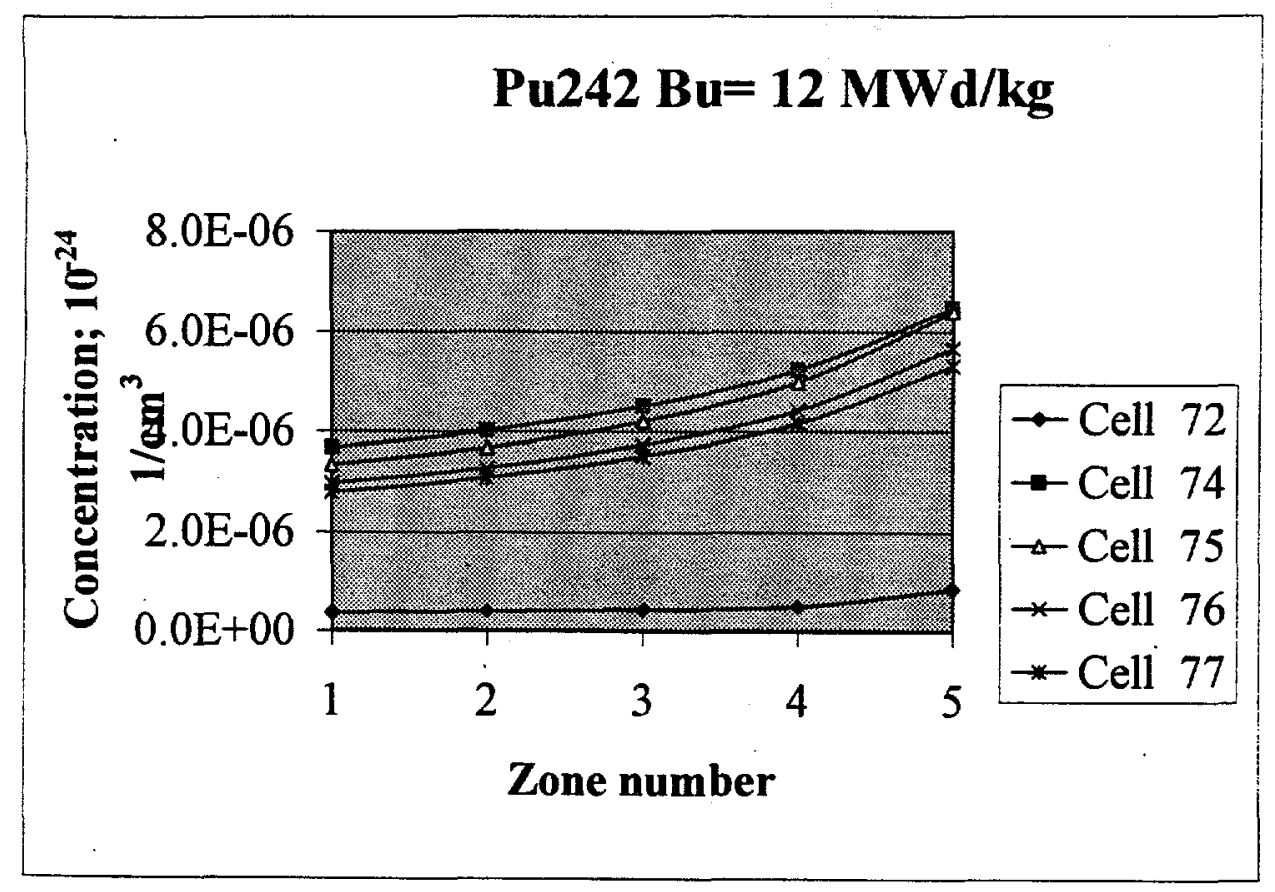

Fig. 27.

Inter-pin isotopic distribution

\section{Pu242 BU= $40 \mathrm{MWd} / \mathrm{kg}$}

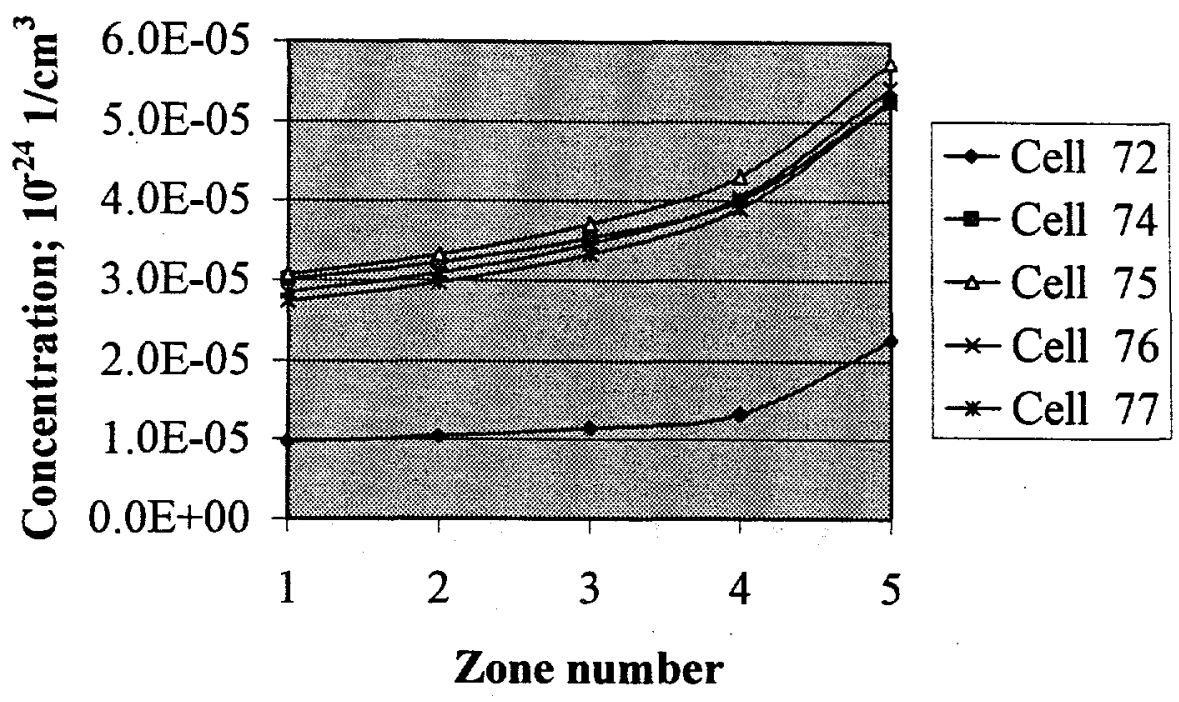

Fig. 28.

Inter-pin isotopic distribution 
H:SIERV AMIDATAWU3Z DU38 "0
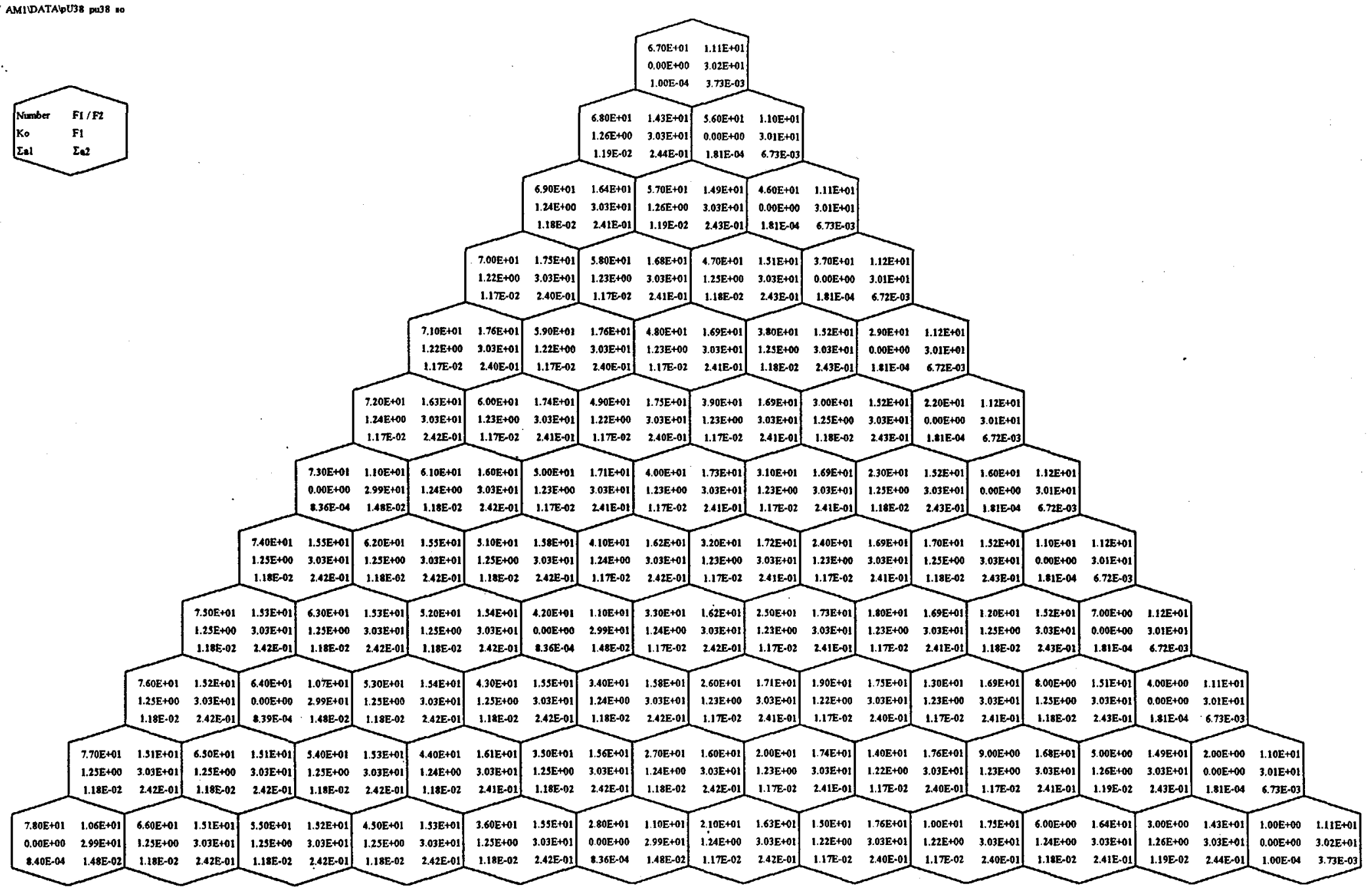

Fig. 29. Spectrum parameters distribution in MOX assembly ( Pu 3.8. Sector $60^{\circ}$ ) 

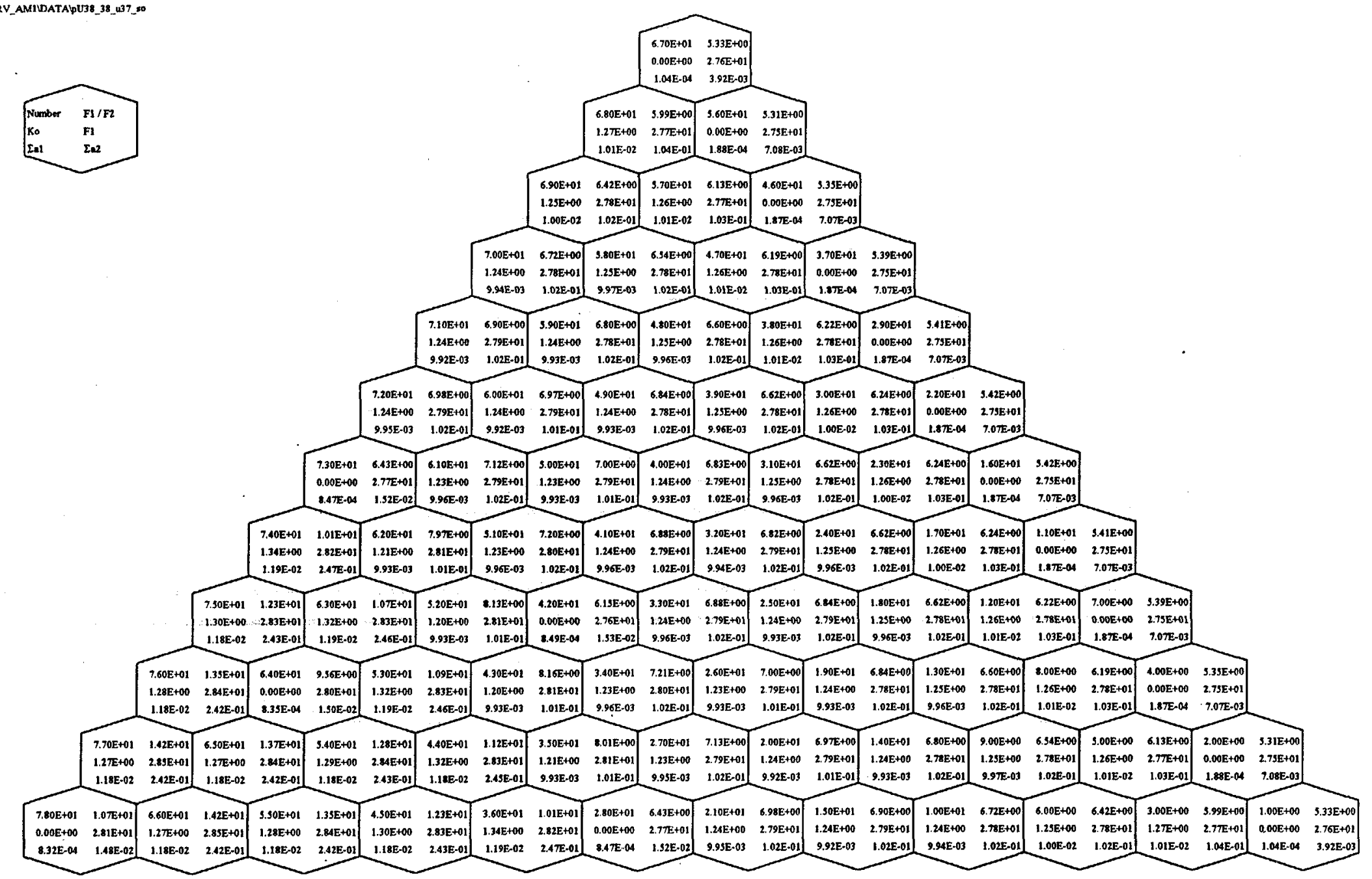

Fig. 30. Spectrum parameters distribution in "Island" type MOX assembly ( Pu 3.8_3.8_U 3.7. Sector $60^{\circ}$ ) 

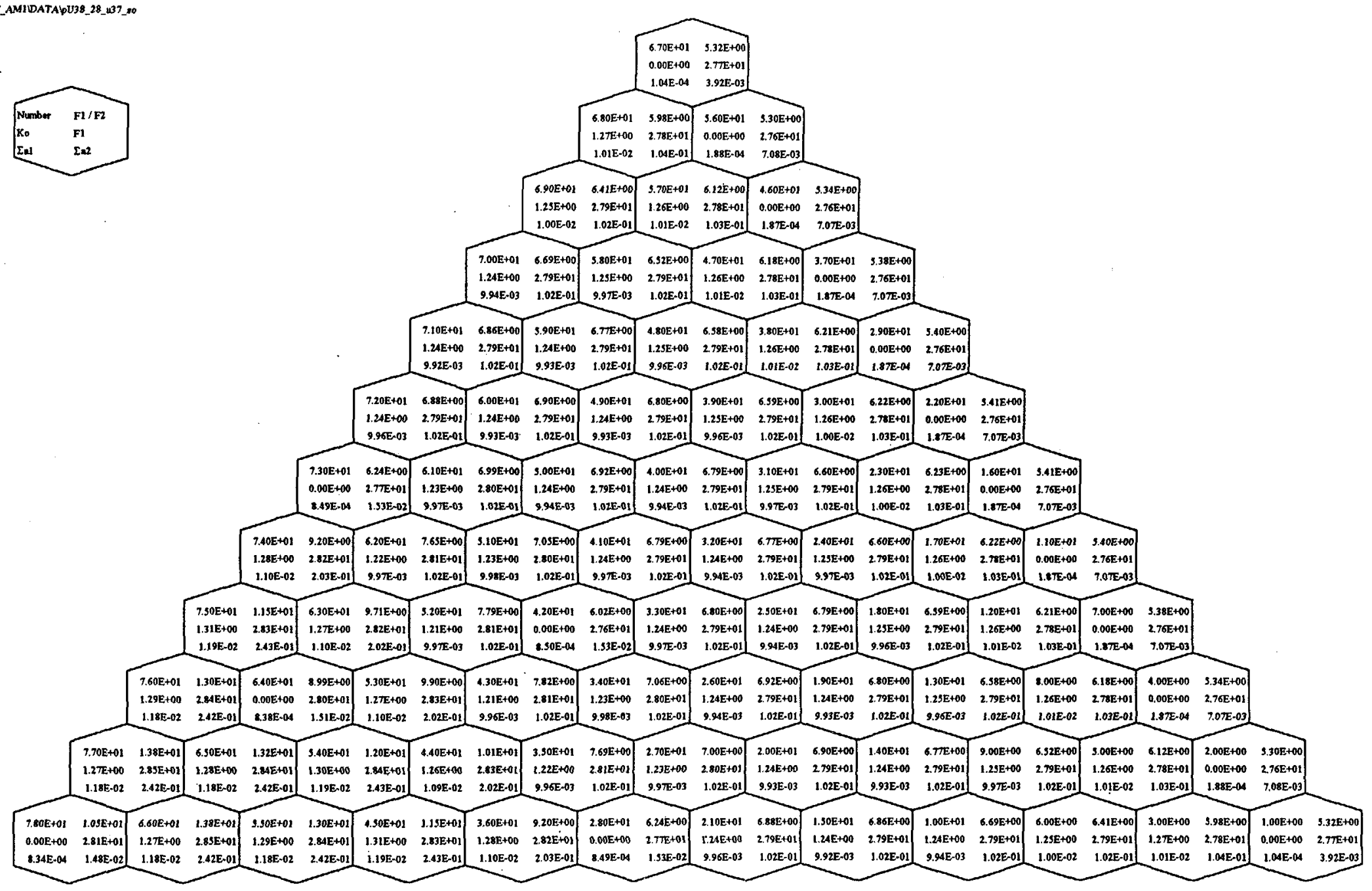

Fig. 31. Spectrum parameters distribution in "Island" type MOX assembly ( Pu 3.8_2.8_U 3.7. Sector 60o) 
pu38 28 u37o

Current Burnup $24 \mathrm{MWtd} / \mathrm{kg}$

Power Distribution

\begin{tabular}{|c|c|c|c|c|c|c|c|c|c|c|}
\hline - 437 & & & & & & & & & & 68 \\
\hline Bur & $24 \mathrm{MWt}$ & & & & & & & & & 1.034 \\
\hline Distr & & & & & & & & & & \\
\hline & & & & & & & & & 69 & 57 \\
\hline & & & & & & & & & 1.003 & 1.024 \\
\hline & & & & & & & & 70 & 58 & 47 \\
\hline & & & & & & & & 0.981 & 0.993 & 1.019 \\
\hline & & & & & & & 71 & 59 & 48 & 38 \\
\hline & & & & & & & 0.973 & 0.976 & 0.99 & 1.016 \\
\hline & & & & & & 72 & 60 & 49 & 39 & 30 \\
\hline & & & & & & 0.986 & 0.974 & 0.976 & 0.989 & 1.015 \\
\hline & & & & & 73 & 61 & 50 & 40 & 31 & 23 \\
\hline & & & & & 0 & 0.989 & 0.977 & 0.978 & 0.989 & 1.015 \\
\hline & & & & 74 & 62 & 51 & 41 & 32 & 24 & 17 \\
\hline & & & & 0.951 & 0.991 & 0.991 & 0.988 & 0.98 & 0.989 & 1.015 \\
\hline & & & 75 & 63 & 52 & 42 & 33 & 25 & 18 & 12 \\
\hline & & & 1.108 & 0.954 & 0.99 & 0 & 0.988 & 0.978 & 0.989 & 1.016 \\
\hline & & 76 & 64 & 53 & 43 & 34 & 26 & 19 & 13 & 8 \\
\hline & & 1.1 & 0 & 0.953 & 0.988 & 0.99 & 0.977 & 0.976 & 0.99 & 1.019 \\
\hline & 77 & 65 & 54 & 44 & 35 & 27 & 20 & 14 & 9 & 5 \\
\hline & 1.091 & 1.097 & 1.105 & 0.948 & 0.989 & 0.988 & 0.974 & 0.976 & 0.993 & 1.024 \\
\hline 78 & 66 & 55 & 45 & 36 & 28 & 21 & 15 & 10 & 6 & 3 \\
\hline 0 & 1.091 & 1.1 & 1.108 & 0.951 & 0 & 0.986 & 0.973 & 0.981 & 1.003 & 1.034 \\
\hline - 437 & & & & & & & & & & 68 \\
\hline Burn & $10 \mathrm{MWt}$ & & & & & & & & & 1.011 \\
\hline Distr & & & & & & & & & & \\
\hline & & & & & & & & & 69 & 57 \\
\hline & & & & & & & & & 0.998 & 1.006 \\
\hline & & & & & & & & 70 & 58 & 47 \\
\hline & & & & & & & & 0.987 & 0.993 & 1.004 \\
\hline & & & & & & & 71 & 59 & 48 & 38 \\
\hline & & & & & & & 0.984 & 0.985 & 0.991 & 1.003 \\
\hline & & & & & & 72 & 60 & 49 & 39 & 30 \\
\hline & & & & & & 0.994 & 0.986 & 0.985 & 0.991 & 1.002 \\
\hline & & & & & 73 & 61 & 50 & 40 & 31 & 23 \\
\hline & & & & & 0 & 0.999 & 0.989 & 0.987 & 0.991 & 1.002 \\
\hline & & & & 74 & 62 & 51 & 41 & 32 & 24 & 17 \\
\hline & & & & 0.942 & 1.014 & 1.003 & 0.995 & 0.988 & 0.991 & 1.002 \\
\hline & & & 75 & 63 & 52 & 42 & 33 & 25 & 18 & 12 \\
\hline & & & 1.061 & 0.949 & 1.016 & 0 & 0.995 & 0.987 & 0.991 & 1.003 \\
\hline & & 76 & 64 & 53 & 43 & 34 & 26 & 19 & 13 & 8 \\
\hline & & 1.078 & 0 & 0.95 & 1.016 & 1.002 & 0.989 & 0.985 & 0.991 & 1.004 \\
\hline & 77 & 65 & 54 & 44 & 35 & 27 & 20 & 14 & 9 & 5 \\
\hline & 1.086 & 1.081 & 1.067 & 0.947 & 1.013 & 0.999 & 0.986 & 0.985 & 0.993 & 1.006 \\
\hline 78 & 66 & 55 & 45 & 36 & 28 & 21 & 15 & 10 & 6 & 3 \\
\hline 0 & 1.086 & 1.078 & 1.061 & 0.942 & 0 & 0.994 & 0.984 & 0.987 & 0.998 & 1.011 \\
\hline
\end{tabular}

pu38_28_u37o

Current Burnup $40 \mathrm{MWtd} / \mathrm{kg}$

Power Distribution

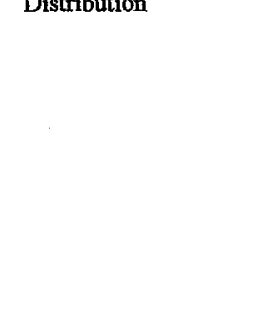

Fig. 33. Power distribution evolution in "Island" type MOX assembly (Pu3.8_2.8_U3.7 Sector 60') 


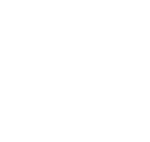

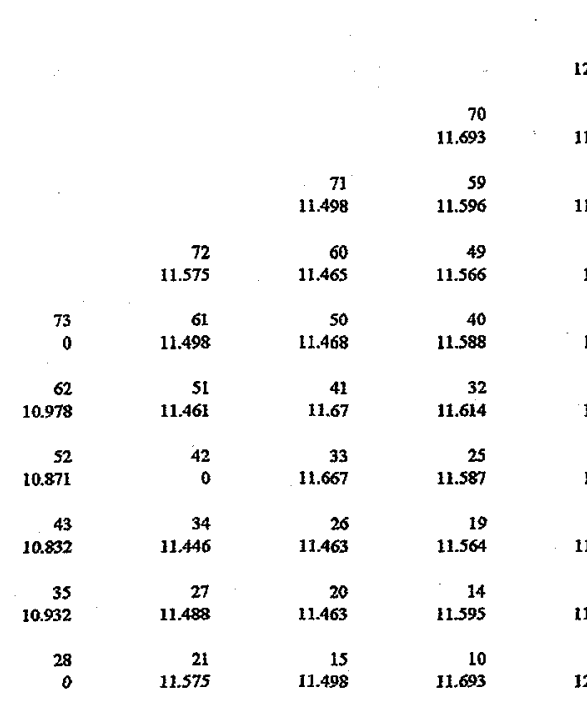

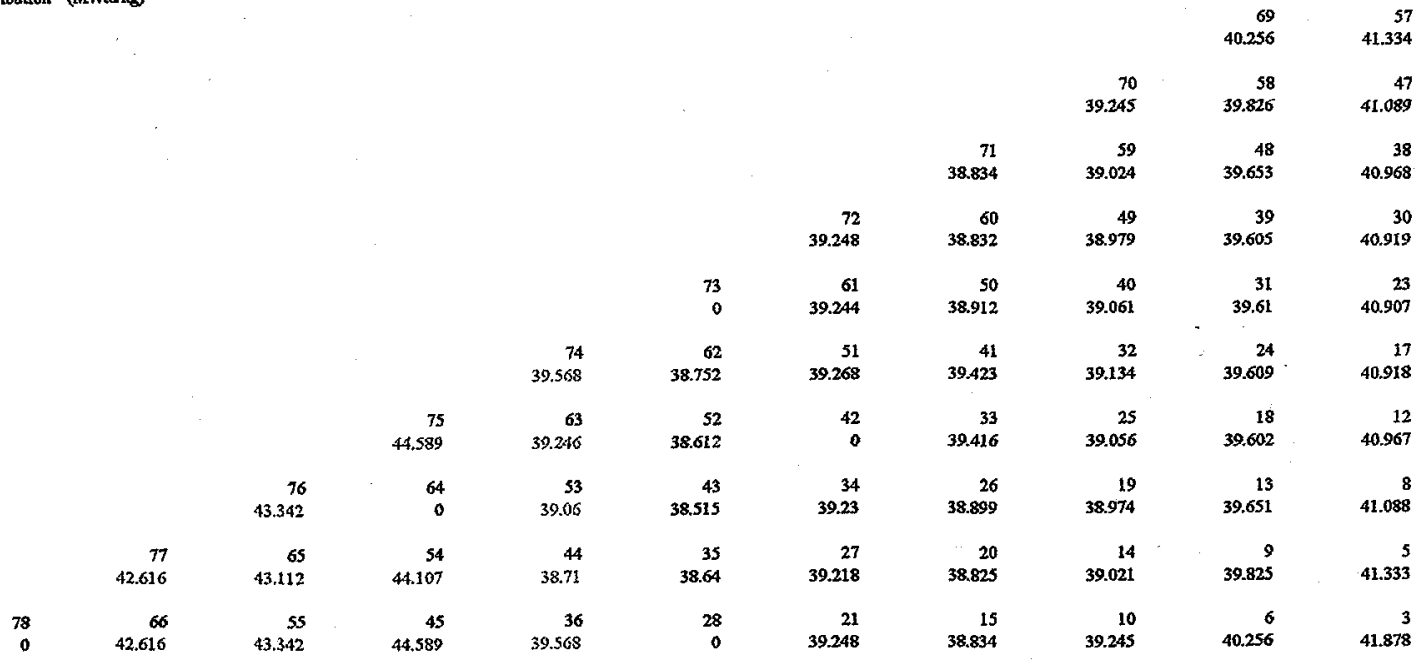

Fig. 34. 

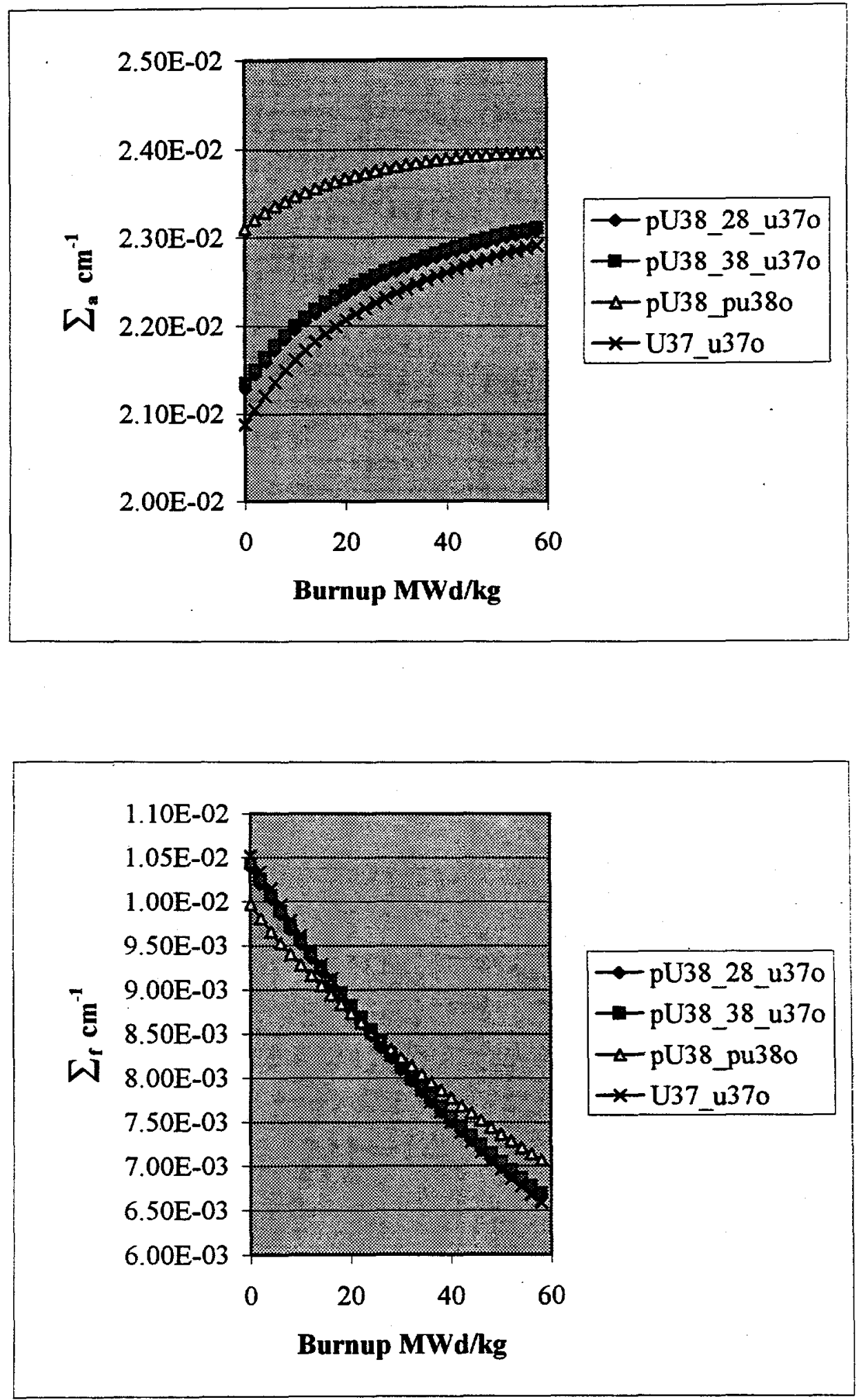

Fig. 35. Assembly parameters evolution for different enrichment compositions 